NBER WORKING PAPER SERIES

\title{
THE LABOR MARKET EFFECTS OF OFFSHORING BY U.S. MULTINATIONAL FIRMS
}

\author{
Brian K. Kovak \\ Lindsay Oldenski \\ Nicholas Sly \\ Working Paper 23947 \\ http://www.nber.org/papers/w23947 \\ NATIONAL BUREAU OF ECONOMIC RESEARCH \\ 1050 Massachusetts Avenue \\ Cambridge, MA 02138 \\ October 2017, Revised October 2019
}

The statistical analysis of firm-level data on U.S. multinational companies was conducted at the Bureau of Economic Analysis, U.S. Department of Commerce under arrangements that maintain legal confidentiality requirements. The authors would like to thank William Zeile, Raymond Mataloni, and James Fetzer for assistance with the BEA data and James Albertus, Nathan Anderson, David Atkin, Brian Cadena, Dave Donaldson, Andrew Goodman-Bacon, Jim Hines, David Hummels, Ben Keys, Peter Morrow, Greg Wright, and participants at various conferences and seminars for helpful discussions. Benjamin Mayer provided excellent research assistance. The views expressed herein are those of the authors and do not reflect official positions of the U.S. Department of Commerce nor the views of the Federal Reserve Bank of Kansas City, Federal Reserve System, or the National Bureau of Economic Research. Nicholas Sly gratefully acknowledges financial support from the WE Upjohn Institute received while at the University of Oregon.

NBER working papers are circulated for discussion and comment purposes. They have not been peer-reviewed or been subject to the review by the NBER Board of Directors that accompanies official NBER publications.

(C) 2017 by Brian K. Kovak, Lindsay Oldenski, and Nicholas Sly. All rights reserved. Short sections of text, not to exceed two paragraphs, may be quoted without explicit permission provided that full credit, including $(\odot$ notice, is given to the source. 
The Labor Market Effects of Offshoring by U.S. Multinational Firms

Brian K. Kovak, Lindsay Oldenski, and Nicholas Sly

NBER Working Paper No. 23947

October 2017, Revised October 2019

JEL No. F16,F23,F66,J20,J30

\section{ABSTRACT}

We use firm-level data on U.S. multinationals to show how offshoring affects domestic employment within and across firms. We introduce a new instrument for offshoring: Bilateral Tax Treaties, which reduce the cost of offshore activities. We find substantial heterogeneity in effects. A 10 percent increase in affiliate employment drives a 1.3 percent increase in employment at the U.S. parent firm, with smaller effects at the industry and regional levels. In contrast, offshoring by vertical multinationals drives declining employment among nonmultinationals in the same industry, and firms opening new affiliates exhibit smaller domestic employment growth than those expanding existing affiliates.

Brian K. Kovak

H. John Heinz III College

Carnegie Mellon University

4800 Forbes Avenue, HBH 3012

Pittsburgh, PA 15213

and NBER

bkovak@cmu.edu

Lindsay Oldenski

Georgetown University

37th and O Streets, NW

Washington DC, 20057

Lindsay.Oldenski@georgetown.edu
Nicholas Sly

Federal Reserve Bank of Kansas City

1 Memorial Dr

Kansas City, MO 64198

Nick.Sly@kc.frb.org 


\section{Introduction}

In recent years, the question of how offshoring affects domestic employment has been at the forefront of political and popular discussions of international economic policy. In spite of the salience of this question, there is little agreement among academic economists regarding the sign of offshoring's effects on domestic labor market outcomes, let alone the magnitude 11 This is in large part because the term "offshoring" comprises many different activities. Offshoring may take place within a multinational firm or at arm's length. Firms may relocate U.S. production to new plants in other countries, or they may increase their output at existing offshore locations. The work performed in the U.S. may differ from the work performed offshore. These different dimensions of offshoring decisions could have different effects not only on the workers at the firm doing the offshoring, but also on workers at competing firms within the same industry or in supporting industries within the same geographic location.

We present a consistent framework to study the effects of offshoring on employment within U.S. multinational firms, at all firms in a given U.S. industry, and for all workers in a given region, with changes in effective tax rates of foreign affiliates serving as an instrument for offshore employment. We combine data on U.S. multinational enterprises (MNEs) from the U.S. Bureau of Economic Analysis (BEA) and broader industry employment within County Business Patterns data to highlight differences in the effects of offshoring across industries (with high vs. low reliance on royalties, interest, and dividends), due to various offshoring margins (extensive vs. intensive), and between organizational forms (domestic vs. multinational). Our results show that these distinctions matter. A 10 percent increase in affiliate employment drives a 1.3 percent increase in employment at the U.S. parent firm, with smaller effects at the industry and regional levels. In contrast, increased foreign affiliate activity in vertically oriented multinational firms drives declining employment among nonmultinationals in the same industry, and multinational firms opening new affiliates exhibit smaller domestic employment growth than those expanding existing affiliates. Overall, our results indicate that greater offshore activity modestly raises net employment by U.S. firms, albeit with substantial job loss and employment reallocation.

Any empirical analysis of the labor market effects of offshoring is complicated by the

\footnotetext{
${ }^{1}$ For example, Desai et al. (2009) find a positive relationship between domestic labor market outcomes and offshoring activities of U.S. multinationals, while Muendler and Becker (2010) find negative effects for German multinational firms, and Monarch et al. (2014) find negative employment effects of offshoring for U.S. firms participating in the Trade Adjustment Assistance program. Harrison and McMillan (2011) provide evidence from the U.S. that the association between offshore and domestic employment may depend on the type of offshoring activity. The destination of offshore activities may also alter the relationship between domestic and foreign employment; see Brainard and Riker (1997). Rather than positive or negative effects, several studies find null impacts of offshoring on domestic labor market outcomes, e.g. Slaughter (2000, 2001), Ottaviano et al. (2013), and Antràs et al. (2017).
} 
fact that offshore activity and domestic employment both reflect choices made by firms, making it difficult to disentangle the causal relationships between the two phenomena. To overcome this inherent simultaneity between domestic and offshore employment, we exploit a policy instrument that alters the relative costs of offshore activity and is exogenous to firm choices - bilateral tax treaties (BTTs). These treaties allow U.S. firms to avoid double taxation, in which foreign affiliate income is taxed in two jurisdictions due to constraints on the size of the foreign tax credit available to U.S.-owned firms. BTTs make this constraint less likely to bind, lowering the average effective tax rate on income from foreign affiliates, hence lowering the overall cost of offshore activity. During our sample period of 1987-2007, countries accounting for 23 percent of total foreign affiliate employment of U.S. multinational firms received new BTTs with the U.S. We leverage variation in the timing of these treaties, the pre-existing country mix of multinational firms' affiliates, and the incidence of double taxation across industries to infer the causal effect of BTT-induced changes in foreign affiliate employment on changes in U.S. domestic employment.

To motivate our empirical analysis we use the model of multinational firm organization developed by Antràs and Helpman (2004). $!^{2}$ This framework i) demonstrates the simultaneity of employment decisions at a domestic parent and its foreign affiliates, ii) characterizes the division of revenue between multinational parents and affiliates, which is necessary to address double-taxation, iii) characterizes sourcing decisions within and across both country and firm boundaries, dimensions of offshoring that have different implications for U.S. employment, and iv) yields a panel difference-in-differences estimation strategy, with changes in effective tax rates of foreign affiliates serving as an instrument for offshore employment.

We rule out the presence of confounding pre-trends using an event-study framework demonstrating similar employment trends for affected and unaffected firms prior to BTT implementation. This analysis also documents positive (reduced-form) effects of BTTs on domestic employment in multinational firms, with results concentrated in industries with relatively high royalty, interest, and dividend payments (RID) to the parent. This is to be expected since the pre-treaty incidence of double-taxation - and thus the benefit of a BTT is larger for firms in high RID industries ${ }^{3}$ RID payments are subject to foreign withholding taxes, which often place total foreign tax payments above the maximum level of the U.S. foreign tax credit, resulting in double taxation. We also find a strong positive (first-stage)

${ }^{2}$ See Feenstra and Hanson (2005) and Defever and Toubal (2013) for empirical support of the property rights/incomplete contracts theory of multinational firms.

${ }_{3}^{3}$ Blonigen et al. (2014) provides evidence that the effects of BTTs vary across U.S. industries according to the use of differentiated inputs. Highly differentiated products tend to have higher markups and so more revenue that is exposed to double taxation. Rather than use a proxy for the degree to which income is subject to double taxation, here we use initial royalty, interest, and dividend payments at the industry level to assess directly the exposure to treatment from BTTs. 
effect of BTTs on foreign-affiliate employment, but only in high RID industries. The absence of effects in low RID industries helps rule out identification concerns regarding other policy reforms that might have occurred simultaneously with BTTs.

For our exclusion restriction to hold, it must be the case that BTTs only impact the domestic hiring decisions of U.S. firms through their effect on foreign affiliates. We offer several pieces of evidence supporting this assumption. First, BTTs reduce the tax burden on foreign affiliate activities, leaving the taxation of domestic activity unchanged. Second, the vast majority of double-taxation cases involving U.S.-owned firms are raised in the foreign affiliate's country, suggesting that this is where the costs of double taxation are incurred (Ernst and Young, 2015). Third, we show that firms in industries that are less likely to be subject to double taxation exhibit no reduced-form relationship between BTTs and U.S. employment, nor do they have significant first stage results linking BTTs with foreign affiliate employment. These relationships only exist for the sample of firms in industries with relatively large royalty, interest, and dividend payments to the parent, payments that are the source of double taxation, again supporting the exclusion assumption Angrist and Pischke 2009 p.131). Finally, our IV estimates are significantly smaller than the corresponding OLS results and are less than one third the magnitude of estimates in the most closely related prior literature (Desai et al., 2009), which suggests that our instrument substantially ameliorates upward simultaneity bias.

In addition to our firm-level analysis we use County Business Patterns data to study employment outcomes for overall national industries and regional labor markets. The industry perspective allows us to capture two margins that are absent in the analysis of multinational firms alone. First, changes in employment at multinational parents may be partly offset by equilibrium employment adjustment at other domestic firms in the same industry. Second, declining costs of offshore activity will likely motivate some firms to become multinational firms by opening new affiliates. Both margins predict smaller effects at the industry level than at the multinational parent level, and this is what we find. The effect within multinational parents is much smaller than the overall industry employment effect, and employment at non-multinational firms significantly declines in response to increased offshore activity at vertically oriented multinational firms in the same industry, suggesting substitution of intermediate input purchases from domestic suppliers to foreign affiliates adversely affects domestic employment. Finally, we examine effects at the regional level, capturing potential spillovers across industries in the same metropolitan area. We generate a regional measure of offshoring exposure as a weighted average of industry-level foreign affiliate employment, with weights reflecting the market's initial industry mix, using a procedure similar to Topalova (2010), Autor et al. (2013), and Kovak (2013). As before, we instrument for observed affiliate 
employment using BTTs. The metro-area estimates are somewhat larger in magnitude than the industry results, consistent with the presence of cross-industry spillovers at the regional level.

Our paper contributes in a variety of ways to the literature on the labor market effects of offshoring. We introduce Bilateral Tax Treaties as a new source of identifying policy variation in the effective cost of offshore activity Although BTTs have been extensively studied in prior work, to our knowledge they have not been used to examine the domestic labor market effects of offshoring $!^{5}$

Other work has documented that the relationship between offshore and domestic employment varies according to the affiliate country (Brainard and Riker, 1997) and the type of offshoring activity (Harrison and McMillan, 2011). By examining outcomes at different levels of aggregation and for different subsamples, we are also able to capture heterogeneity in the effects of offshoring across firms with different organizational forms and different offshoring margins. For example, our parent-level analysis suggests that extensive-margin offshoring (opening new affiliates in response to cost reductions) does not significantly affect domestic employment within multinationals, while intensive-margin adjustments (increasing employment at existing affiliates) increase domestic employment. These findings suggest that there is not a single effect of increased offshore activity on domestic employment, but that the effects vary depending on the circumstances, potentially explaining differences in empirical findings across research papers..$^{6}$

This observation also has important implications for relating our findings to others in the broader literature on the effects of increased imports, which tends to find negative effects of total imports on labor market outcomes (e.g. Autor et al. (2013), and Hummels et al. (2014)). Total imports include final goods, inputs purchased abroad at arms-length, and inputs purchased from foreign affiliates of domestic multinationals. Each of these trade flows may have a different effect on domestic labor market outcomes and is subject to different

\footnotetext{
${ }^{4}$ Closely related prior work uses variation based at least partly on year-to-year changes in affiliate-country GDP (Desai et al. 2009) or wages (Brainard and Riker, 1997; Slaughter, 2000, Muendler and Becker, 2010. Harrison and McMillan, 2011). Permanent reductions in the cost of offshore activity following a a BTT more closely parallel the secular declines in offshoring costs during recent decades

${ }^{5}$ See, for example, Blonigen and Davies (2004), Davies (2004), di Giovanni (2005), Egger et al. (2006), Louie and Rousslang (2008), Davies et al. (2009), and Blonigen et al. (2014).

${ }^{6}$ For example, we find positive net effects on domestic employment while a recent paper by Boehm et al. (2017) find declining domestic employment in response to offshoring. Their analysis restricts attention to U.S. manufacturing establishments, omitting the headquarters establishments where positive scale effects are most likely to emerge. They also observe offshoring at arms-length and extensive margin offshoring at newly formed multinationals. Both of these margins likely contribute to domestic employment declines but are unobservable in the BEA data. In contrast, Suárez Serrato (2018) examines the effects of an effective tax increase on firms with existing affiliates, in which scale effects are most likely to dominate, finding domestic employment effects consistent with ours.
} 
policy interventions. We focus on the effects of increased employment at foreign affiliates of U.S. multinational firms, both to take advantage of a compelling policy-based identification strategy and because the potential effects of offshoring by multinational firms have been the topic of much attention in political debates and the popular press, distinct from discussions of trade more broadly. Moreover, the U.S. Census Bureau reports that about 50 percent of U.S. imports are between related parties, and Slaughter (2009) discusses evidence that MNEs account for approximately 20 percent of total employment in the U.S. Hence, the type of offshoring we consider here is of first-order importance to U.S. labor market outcomes.

Our research design explicitly measures the overall effects of declining costs of offshore activity, including potential substitution and scale effects. This approach is distinct from that in papers estimating substitution parameters in multinational firm-level cost functions, which explicitly hold firm output fixed to isolate substitution effects.7 In our framework, the key mechanism driving the positive relationship between domestic and offshore affiliate employment is that firms may expand output, and thus employment, as offshoring costs fall. Hence, our positive estimates are entirely consistent with prior work finding that foreign and domestic employment are substitutes, since our estimates reflect a combination of substitution and scale effects. Moreover, we find independent evidence for the quantitative importance of substitution effects by showing smaller employment growth in firms opening new affiliates in BTT countries, a margin in which substitution effects are most important.

The following section describes Bilateral Tax Treaties and the data we utilize to study their effects. Section 3 estimates the reduced-form effect of BTTs on domestic employment in multinational firms, emphasizing that the appearance of BTTs was uncorrelated with pre-existing firm employment growth. Section 4 presents our main analysis, studying how increased offshore employment affects domestic employment. This includes the theoretical framework, analysis of how BTTs affect foreign affiliate employment, and results for the effects of offshoring at the multinational parent, industry, and regional levels. Section 5 concludes.

\section{Background and Data}

This paper identifies the effects of offshore employment on domestic employment using variation in offshore activity driven by Bilateral Tax Treaties (BTTs). BTTs resolve a problem called "double taxation" in which limits on the amount of foreign tax credits available to

\footnotetext{
${ }^{7}$ e.g. Slaughter (2000) and Muendler and Becker (2010). Harrison and McMillan (2011) control for output by assuming that firm output depends only upon domestic and foreign prices and then empirically proxying for those prices using industry sales.
} 
U.S. MNEs result in the same income being taxed in two jurisdictions, potentially raising the effective tax rate for foreign affiliates well above the statutory level in either jurisdiction.

In particular, during our sample period the U.S. corporate tax applied to worldwide profits, meaning that profits resulting from a U.S. multinational firm's activities both at home and abroad were subject to the U.S. corporate tax. This is in contrast to territorial systems, in which foreign affiliate activity is only taxed by the country in which the affiliate is located..$^{8}$ Under the U.S.'s worldwide system, any foreign tax on foreign affiliate activity would subject the firm to double taxation in the absence of some compensation. In an effort to limit this possibility, the U.S. government offers a foreign tax credit to U.S. firms to offset their foreign tax liabilities.9 ${ }^{9}$ However, a U.S. multinational firm may not claim a foreign tax credit that exceeds the U.S. tax on foreign taxable income, otherwise the U.S. IRS would implicitly subsidize the foreign tax authority. When the foreign tax liability exceeds this limit, a portion of the firm's income is taxed by both the U.S. and foreign taxing authorities without an offsetting credit.

Double taxation of this kind is most likely to arise when the foreign jurisdiction imposes a substantial tax on royalties, interest, or dividends, known as a "withholding tax." These rates can be quite high, so that the combined corporate income tax and withholding tax in many foreign jurisdictions can exceed the relatively high U.S. corporate tax rate. In this circumstance, the firm owes withholding taxes to the foreign tax authority without receiving a fully offsetting credit, resulting in double taxation and imposing additional costs on the foreign activities of the firm.

To see how lowering withholding tax rates helps avoid double taxation, consider a hypothetical situation in which a U.S. multinational firm has an affiliate in Mexico that earns $\$ 100$ of taxable income, $\$ 60$ of which is paid to the U.S. parent in the form of royalties. Before a BTT is in place, the Mexican tax authority levies a 25 percent withholding tax on the $\$ 60$ of royalty payments plus a 35 percent tax on the $\$ 40$ earned in its jurisdiction. In this scenario the foreign tax authority collects $\$ 29(=0.25 * 60+0.35 * 40)$ from the foreign affiliate. Yet, the U.S. foreign tax credit limit is $\$ 14(=0.35 * 40)$, reflecting the 35 percent U.S. corporate tax rate applied to the value of Mexican activity. As a result, the foreign affiliate is left with $\$ 15$ in un-credited foreign tax liabilities, subjecting the multinational enterprise to double taxation. If signing a BTT were to eliminate the withholding tax, then the U.S. foreign tax credit would be sufficient to fully offset the taxes paid to the foreign tax authority. Albeit an overly simplified example, this scenario demonstrates how limits on

${ }^{8}$ With the Tax Cuts and Jobs Act of 2017, the U.S. adopted a more territorial corporate tax system so our identification strategy does will not apply after 2017.

${ }^{9}$ See Desai et al. (2001) for an introduction to the U.S. foreign tax credit and Doernberg (2016) Ch. 8 and Misey and Schadewald (2015) Ch. 4 for detailed treatments. 
foreign tax credits can lead to double taxation, and how BTTs can mitigate the problem by reducing withholding tax rates on royalty, interest, and dividend income 10

Table 1 provides information on each of the U.S. BTTs that entered into force during our sample period 1987-2007 [11 These treaty partner countries account for approximately 23 percent of total foreign affiliate employment of U.S. MNEs during our sample period ${ }^{12}$ Table 1 also reports withholding tax rates on royalty, interest, and dividend income facing U.S. multinational firms just before and just after the relevant BTT entered into force. Note the withholding rates under the treaty are often substantially lower than they were prior to the treaty. By reducing these withholding rates, BTTs reduce the probability of double taxation, lowering the effective tax rate faced by multinational firms and incentivizing offshore activity in treaty countries.

Even though BTTs apply to all industries, the effects of BTTs on effective tax rates may vary by industry because of differences in the initial incidence of double taxation. For multinational firms in industries where royalties, interest, and dividends (RID) are higher, the amount of withholding tax levied on foreign affiliate activity is also higher, and double taxation is more likely. In contrast, industries that rely minimally on royalty, interest, and dividend payments are much less likely to face double taxation. Hence, we expect the effects of BTTs to be larger in industries with relatively high RID payments. Appendix A.2 describes in detail our categorization of industries with high or low RID payments.

Our empirical analyses examine the effects of BTTs on employment in U.S. multinational firms, their foreign affiliates, and the broader labor market. Information on multinational firms comes from the 1987-2007 Surveys of U.S. Direct Investment Abroad, collected by the Bureau of Economic Analysis (BEA). These data provide a quasi-exhaustive sample of U.S. multinational firms and their affiliates in foreign countries. Our analysis utilizes information on domestic employment at the U.S. parent firm and employment in each of its majority-owned foreign affiliates, along with information on each parent firm's 3-digit primary industry ${ }^{13}$ Firm-level data are ideal in this context, as they allow us to control for

\footnotetext{
${ }^{10}$ Note that the prospect of double taxation arising from withholding taxes may deter firms from making royalty, interest, or dividend payments (Desai et al., 2001). Even in this case, lowering withholding taxes through a BTT lowers effective costs, since it allows the firm to allocate resources with less distortion.

${ }^{11}$ Treaties are often signed in years prior to when they become effective, and several BTTs have been renegotiated over time. We use the date in which the original signing entered into force to indicate when countries have a treaty in place. See IRS.gov, United States Income Tax Treaties A-Z for treaty text, including relevant dates. Our event-study analysis in Figure 1 below shows no sign of anticipatory effects, supporting this timing definition. See Appendix A.1 for a visualization of our sample's time coverage relative to BTT dates.

${ }^{12}$ Authors' calculations using the BEA Surveys of U.S. Direct Investment Abroad.

${ }^{13}$ We classify affiliates based on their parent's primary industry. The BEA uses 3-digit SIC-based ISI codes prior to 1999 and uses 4-digit NAICS-based ISI codes afterwards. For consistency, we convert NAICS-based codes to 3-digit SIC-based codes for the relevant years.
} 
time-invariant unobservable firm or affiliate characteristics and to investigate heterogeneity in effects based on offshoring margin and firm organizational structure. Our sample includes 5,715 firms with 46,498 foreign affiliates spanning 121 3-digit industries and operating in 130 countries from 1987 to 2007 . Note that our sample includes all multinational firms, including those outside manufacturing.

After examining outcomes within multinational firms, we consider employment effects at the industry and regional levels using data on employment by industry and metropolitan statistical area (MSA) from the U.S. Census Bureaus's County Business Patterns (CBP). These data report total employment at private business establishments in covered industries by industry and county. 14 We aggregate industries to match the 3-digit classification used in the BEA data and aggregate counties to construct 304 time-consistent metropolitan areas spanning our sample period.

Throughout our analyses, we present specifications controlling for a standard set of timevarying country-level determinants of offshoring, using data compiled from several sources.15 Control variable names appear in square brackets. To capture the regularities that greater national incomes promote foreign affiliate activity, while large differences in national income reduce it, we control for the log of the sum of U.S. and affiliate country's real GDP $\left[\ln \left(G D P_{u s}+G D P_{d}\right)\right]$ and the $\log$ of the squared difference in the two countries' GDPs $\left[\ln \left(\left(G D P_{u s}-G D P_{d}\right)^{2}\right)\right]$. Information regarding real GDP and trade costs come from the Penn World Tables, with national incomes expressed in trillions of U.S. dollars. Trade costs are measured using a standard definition of openness: the log of 100 minus the trade share of total GDP $[\ln ($ Trade Costs)]. The skill difference between the U.S. and a foreign affiliate country is measured as the log of the difference in average educational attainment [ln(Skill Difference)] from Barro and Lee (2010). Educational attainment measures are available every five years, so we linearly interpolate data for years between observations. Data indicating whether the U.S. has a bilateral investment treaty [BIT] with the destination country are from the United Nations Conference on Trade and Development. The presence of free trade agreements [FTA] across countries is available from the U.S. Trade Representative. Annual exchange rate data [Exchange Rate] are from the World Bank.

Table 2 reports summary statistics for the all foreign affiliates in our sample and the U.S. parent firms that own them. The average firm in our sample has roughly 9 foreign affiliates with total foreign employment of 3513 workers and total U.S. employment of 7906 workers.

\footnotetext{
${ }^{14}$ The CBP data provide full coverage in all industries except crop and animal production; rail transportation; National Postal Service; pension, health, welfare, and vacation funds; trusts, estates, and agency accounts; private households; and public administration.

${ }^{15}$ See Carr et al. (2001), di Giovanni (2005), and Blonigen et al. (2014) for papers motivating these controls.
} 


\section{Effects of BTTs at U.S. Multinationals}

Before moving on to our theoretically motivated IV estimates of the effects of offshoring on U.S. employment, we begin our empirical analyses by estimating the effect of BTTs on U.S. parent firm employment. This analysis is the reduced form of the simultaneous equations framework introduced in Section 4.1, and serves two purposes. First, the effect of BTTs on multinational firm hiring in the U.S. is of independent interest, as tax treaties are among the most commonly implemented policy tools affecting the incentives to engage in cross-border production, and they help inform us about the broader consequences of changes in effective tax rates for multinational firms. Second, this analysis allows us to rule out the presence of confounding trends, in which faster growing multinational firms are systematically more or less likely to have affiliates in countries signing new BTTs with the U.S.

We estimate the effect of BTTs on parent employment using a panel difference-in-differences research design (Bertrand et al., 2004). In order to have a single well-defined treatment period for each parent firm, here we focus on the first BTT received by one of the parent's affiliates during our sample period. A parent firm is treated when at least one of the countries hosting its affiliates has enacted a new BTT with the U.S. during our sample period. Define $\tilde{t}_{f}$ as the first year in which an affiliate of firm $f$ receives a BTT, so the firm is treated when $t \geq \tilde{t}_{f}$. To account for differences in the relative importance of the first affiliate receiving a BTT, we scale the treatment indicator by that affiliate's pre-BTT share of the parent firm's total affiliate employment, $\tilde{\varphi}_{f}$ estimate the following 16

$$
\ln s_{f t}=\beta^{R F}\left[\tilde{\varphi}_{f} \mathbf{1}\left(t \geq \tilde{t}_{f}\right)\right]+\Gamma X_{f t}+\lambda_{f}+\nu_{i t}+\epsilon_{f t},
$$

where $s_{f t}$ is U.S. employment at parent firm $f$ in year $t ; \mathbf{1}\left(t \geq \tilde{t}_{f}\right)$ is a treatment indicator for years in which at least one of firm f's affiliates has received a BTT; this treatment indicator is scaled by that affiliate's initial employment share, $\tilde{\varphi}_{f} ; X_{f t}$ is the vector of standard offshoring controls described in Section 2; $\lambda_{f}$ are parent firm fixed effects; $\nu_{i t}$ are industry-year fixed effects; and $\epsilon_{f t}$ is an error term. Because (1) includes fixed effects for each parent firm and for each industry-year combination, $\beta^{R F}$ measures the (reduced form) difference in employment growth for parent firms in the same industry whose affiliates do and do not receive BTTs.

\footnotetext{
${ }^{16}$ To be precise, let $t_{c}$ be the year in which country $c$ enacts a BTT with the U.S., and $t_{c}=\infty$ if the country does not enact a BTT. $C_{f}$ is the set of countries in which firm $f$ initially has affiliates. Then $\tilde{t}_{f} \equiv \min _{c \in C_{f}}\left\{t_{c}\right\}$. Note that $\tilde{t}_{f}=\infty$ if none of $f$ 's affiliates have a BTT during our sample period, so $\mathbf{1}\left(t \geq \tilde{t}_{f}\right)=0$, and $f$ is not treated. Let $\tilde{c}_{f} \equiv \arg \min _{c \in C_{f}}\left\{t_{c}\right\}$ be the first of firm $f$ 's affiliate countries to receive a BTT. Affiliate $\tilde{c}_{f}$ 's pre-BTT share of affiliate employment is then $\tilde{\varphi}_{f} \equiv\left(m_{f, \tilde{c}_{f}, \tilde{t}_{f}-1}\right) /\left(\sum_{c \in C_{f}} m_{f, c, \tilde{t}_{f}-1}\right)$, where $m_{f, c, t}$ is employment at parent firm $f$ 's affiliate in country $c$ in year $t$. We scale by the pre-BTT affiliate employment to avoid including any endogenous employment adjustments.
} 
We calculate two-way cluster-robust standard errors, clustering by parent firm and by year.

The results appear in Table 3. The first column includes firms from all industries, while columns (2) and (3) separately estimate the effects of BTTs in industries with high and low levels of royalty, interest, and dividend (RID) payments. A positive point estimates for the BTT indicator's coefficient implies that parent firms whose affiliates receive BTTs expand employment on average in comparison to parents whose affiliates do not. The effect on all parents in column (1) is statistically insignificant 17 However, when restricting the sample to parents in high RID industries, BTTs have large and statistically significant effects. This is expected since double taxation is more likely in these industries prior to BTT implementation. In contrast, the estimates for low RID industries are much smaller and statistically indistinguishable from zero. Introducing additional controls in columns (4)-(6) yields similar results. The coefficient in column (5) implies that a BTT for a multinational firm with single affiliate in high RID industries increases domestic employment by 6.6 percent. 18

In order to interpret the estimates from (1) as the causal effect of BTTs on MNE parent firm employment, it must be true that parents whose affiliates did and did not receive BTTs would have experienced equal average employment growth in the absence of new BTTs. We test for pre-existing differences in employment trends using the event-study framework of Jacobson et al. (1993), in which we examine the employment effect of a parent's first new BTT in each year before and after it enters into force. The estimation equation, which strictly generalizes the difference-in-differences specification in (1), is

$$
\ln s_{f t}=\sum_{j=-6}^{+6} \beta_{j}^{R F}\left[\tilde{\varphi}_{f} \mathbf{1}\left(t-\tilde{t}_{f}=j\right)\right]+\Gamma X_{f t}+\lambda_{f}+\nu_{i t}+\epsilon_{f t} .
$$

The estimates of $\beta_{j}^{R F}$ measure the difference in employment growth for parent firms in the same industry whose affiliates do and do not receive new BTTs, in year $j$ before or after the BTT was implemented. To rule out potentially confounding pre-BTT trends in parent firm employment growth, we expect $\beta_{j}^{R F} \approx 0 \forall j<0$. We focus on high RID industries, since they exhibited substantial responses to BTTs in Table 3 . Figure 1 plots the estimated coefficients along with their 95 percent confidence intervals, with the year before BTT implementation $(j=-1)$ as the omitted category, equal to zero. The coefficients on the pre-BTT $\hat{\beta}_{j}^{R F}$ are flat and nearly identical to zero, and there is no sign of pre-BTT differences in employment growth for firms that would and would not later be treated. Only in the period of BTT implementation and later do treated and non-treated firms'

\footnotetext{
${ }^{17}$ di Giovanni (2005), Blonigen and Davies (2005), and Davies et al. (2009) also find no robust relationship between BTTs and FDI activity at an aggregate level.

${ }^{18} 100 *(\exp (0.064)-1)=6.6$.
} 
employment growth rates diverge, as indicated by the jump in period 0, in which the BTT was implemented, and growth in the effects over the subsequent years. These results are consistent with prior evidence that increased multinational activity occurs only after BTTs enter into force (Blonigen et al., 2014), and show that BTT assignment is uncorrelated with preexisting firm performance. ${ }^{19}$

Together, the results in this section show that decreasing effective tax rates on foreign affiliate activity by enacting a BTT increases employment at the U.S. parent firm. As we will discuss in detail below, these positive estimates suggest that scale effects, in which lower costs drive increases in overall firm activity, outweigh substitution effects, in which firms shift activity toward the newly cheaper affiliate activities. Statistically and economically significant results appear for parents in high RID industries, which benefit most from removing double taxation, while the effects in low RID industries are indistinguishable from zero.

These findings support the notion that BTTs are exogenous to counterfactual firm employment growth in a variety of ways. The lack of confounding pre-BTT trends in parent employment rules out concerns in which firms that were experiencing stronger employment growth were systematically more likely to have affiliates receiving BTTs. Another potential concern is the presence other time-varying confounders that are correlated with BTTs. A potential example is that some countries listed in Table 1 (e.g. India) implemented other market-based policy reforms around the time their BTT entered into force, potentially confounding the effects of BTTs on employment growth. Unlike BTTs, broader market reforms should affect both high- and low-RID industries, so the lack of any observed effect of BTTs in low RID industries rules out substantial confounding from simultaneous policy reforms. In the following section, we similarly find that BTTs have no effect on affiliate employment in low RID industries. As Angrist and Pischke (2009) argue (p.131), the lack of reduced-form (parent) effect in a subsample with no first-stage (affiliate) effect helps reinforce the idea that BTTs satisfy the exclusion restriction required for the IV analysis in the following section.

\section{Effects of Offshoring on Domestic Employment}

We now turn to studying the more general question of how changes in foreign affiliate hiring affect domestic employment at multinational parent firms and in the broader U.S. labor market. Although this question has been the subject of prior research and is of interest to

\footnotetext{
${ }^{19}$ In Appendix A.3 we implement two alternative versions of this parent-level reduced form analysis. First, we remove the affiliate employment scaling factor, $\tilde{\varphi}_{f}$, and examine the effect of an average BTT irrespective of the relative size of the affected affiliate. Second, we utilize information on all new BTTs experienced by a parent firm's affiliates, not just the first one. In each case we find results consistent with our preferred specification.
} 
policy makers, it is difficult to answer credibly due to the inherent simultaneity between offshore and domestic activity.

\subsection{Theoretical Framework}

We utilize the Antràs and Helpman (2004) global sourcing model to motivate an estimation strategy using BTTs to resolve this simultaneity problem. This particular model suits our context for three reasons. First, it defines the boundary of the firm in an environment with incomplete contracts, allowing us to characterize how the effects of offshoring vary across firms with different organizational forms. Since BTTs only influence effective tax rates for integrated multinationals (not those transacting at arm's length), the firm boundary distinction is essential. Second, by specifying each agent's bargaining position, the framework describes the economic division of revenue across tax jurisdictions, thereby characterizing the respective tax liabilities, and subsequently the potential for double taxation. Finally, the model explicitly characterizes the simultaneity of parent and offshore affiliate employment, yielding a system of linear simultaneous equations justifying a panel difference-in-differences research design using variation in BTTs as an instrument for affiliate employment.

\subsubsection{Fundamentals}

The world economy consists of one home country and $C$ foreign countries. Consumers in all countries are laborers with identical quasi-linear preferences over a homogeneous good, $x_{t 0}$, and a series of composite goods, $X_{t i}$, across industries $i=1 \ldots I$, given by $U_{t}=x_{t 0}+$ $\frac{1}{\mu} \sum_{i=1}^{I} X_{t i}^{\mu}$, with $0<\mu<1$. Consumers have constant elasticity of substitution preferences over unique varieties, $f$, among the set $F_{t i}$ of varieties available in industry $i$ and period

$t$ specified as $X_{t i}=\left[\int_{f \in F_{t i}} x_{t i}(f)^{\alpha_{i}} d f\right]^{1 / \alpha_{i}}$, with $0<\alpha_{i}<1$. It follows that, within each period, monopolistically competitive firms each producing a unique variety, $f$, face an inverse demand function $p_{t i}(f)=X_{t i}^{\mu-\alpha_{i}} x_{t i}(f)^{\alpha_{i}-1}$.

Labor is the only factor of production, with a perfectly elastic supply in all countries. Let $\omega$ be the wage in the home country and $w_{c}$ be the wage in each Foreign country with $\omega>w_{c}$. Workers may either perform headquarters services, $s$, or assembly, $m$, in producing the variety of the final good sold by the firm. Each worker can provide a single unit of headquarters services or assembly services, and the final product for each firm is delivered to consumers by combining headquarters services and assembly according to

$$
x_{t i}(f)=\theta(f)\left[\frac{s_{t}(f)}{\eta_{i}}\right]^{\eta_{i}}\left[\frac{m_{c t}(f)}{1-\eta_{i}}\right]^{1-\eta_{i}}
$$


where $\theta(f)$ is a firm-level productivity parameter. Headquarters services, $s_{t}(f)$, can only be performed domestically, while assembly can take place domestically or at factories in any country $c \in C{ }^{20}$ Regardless of where assembly occurs, the process is firm-specific.

\subsubsection{Offshoring and Double Taxation in Integrated Multinationals}

Firms face an inability to write ex-ante enforceable contracts over the delivery of specialized inputs like R\&D, design, marketing, or the specific processes used during assembly at the factory. Instead, the parent firm and affiliate engage in Nash bargaining over the surplus from their relationship after goods are sold. A multinational enterprise is comprised of a parent firm that supplies headquarters services and integrates with its offshore assembly factory, giving the parent the right to seize outputs from the affiliate after they are produced. However, in the case of seizure the parent loses a share $\left(1-\delta_{c}\right) \in(0,1)$ of final output, which can vary by the location of offshore assembly $c$. The parent's outside option is therefore to seize the goods produced and sell them directly, receiving only a proportion $\delta_{c}^{\alpha_{i}}$ of the revenue that would result had the parent not exercised its rights to claim the assembled output. Thus, the surplus generated by cooperation between the parent and affiliate is a fraction $\left(1-\delta_{c}^{\alpha_{i}}\right)$ of total revenue. The parent company receives a fraction $\beta$ of this surplus, with the remainder going to the foreign affiliate supplier.

The parent's problem is therefore to choose its employment, equivalent to choosing its production of headquarters services $s_{t}(f)$, in order to maximize its profits:

$$
\max _{s_{t}(f)}\left[\delta_{c}^{\alpha_{i}}+\beta\left(1-\delta_{c}^{\alpha_{i}}\right)\right] r_{t i}(f)-\omega s_{t}(f)
$$

where revenue is $r_{t i}(f)=\theta(f)^{\alpha_{i}} X_{t i}^{\mu-\alpha_{i}}\left[\frac{s_{t}(f)}{\eta_{i}}\right]^{\alpha_{i} \eta_{i}}\left[\frac{m_{c t}(f)}{1-\eta_{i}}\right]^{\alpha_{i}\left(1-\eta_{i}\right)}$. The corresponding problem for the affiliate performing assembly in foreign location $c$ is

$$
\max _{m_{c t}(f)}\left[(1-\beta)\left(1-\delta_{c}^{\alpha_{i}}\right)\right] r_{t i}(f)-\tau_{c t i} w_{c} m_{c t}(f)
$$

The term $\tau_{c t i} \geq 1$ is our addition to the Antràs and Helpman (2004) model, reflecting the possibility that the multinational firm faces double taxation. We model double taxation such that the affiliate must hire $\tau_{c t i}>1$ workers to provide one unit of assembly services. The next subsection discusses the motivation for and implications of assuming that the incidence of double taxation falls on the affiliate while leaving the parent's problem unchanged. Note that

\footnotetext{
${ }^{20}$ For simplicity, we assume that domestic and offshore labor inputs are perfect substitutes in performing assembly. Muendler and Becker (2010) find that in the German context they are substitutes, but imperfect ones.
} 
$\tau_{c t i}$ may vary by affiliate country, year, and industry, capturing variation in the timing and presence of BTTs with particular countries, and the fact that the incidence of double taxation is greater in industries with more reliance on royalties, interest, and dividend payments.

\subsubsection{Labor Demand Within Multinational Firms}

A parent firm solves (4) by choosing its employment, $s_{t}(f)$, given its affiliate's employment, $m_{c t}(f)$. This yields the following best-response function for the parent.

$$
\begin{array}{r}
\ln s_{t}(f)=\ln \eta_{i}+\frac{\ln \left[\delta_{c}^{\alpha_{i}}+\beta\left(1-\delta_{c}^{\alpha_{i}}\right)\right]+\ln \alpha_{i}-\ln \omega+\alpha_{i}\left[\ln \theta(f)-\left(1-\eta_{i}\right) \ln \left(1-\eta_{i}\right)\right]}{1-\alpha_{i} \eta_{i}} \\
-\frac{\alpha_{i}-\mu}{1-\alpha_{i} \eta_{i}} \ln X_{t i}+\frac{\alpha_{i}\left(1-\eta_{i}\right)}{1-\alpha_{i} \eta_{i}} \ln m_{c t}(f) .
\end{array}
$$

Similarly, an affiliate in country $c$ solves (5) by choosing its employment, $m_{c t}(f)$, given its parent's employment, $s_{t}(f)$, yielding its best-response function.

$$
\begin{array}{r}
\ln m_{c t}(f)=\ln \left(1-\eta_{i}\right)+\frac{\alpha_{i}\left[\ln \theta(f)-\eta_{i} \ln \eta_{i}\right]+\ln \left(1-\delta_{c}^{\alpha_{i}}\right)+\ln (1-\beta)+\ln \alpha_{i}-\ln w_{c}}{1-\alpha_{i}\left(1-\eta_{i}\right)} \\
\quad-\frac{\alpha_{i}-\mu}{1-\alpha_{i}\left(1-\eta_{i}\right)} \ln X_{t i}+\frac{\alpha_{i} \eta_{i}}{1-\alpha_{i}\left(1-\eta_{i}\right)} \ln s_{t}(f)-\frac{1}{1-\alpha_{i}\left(1-\eta_{i}\right)} \ln \tau_{c t i}
\end{array}
$$

We can more concisely express these two best-response functions by grouping terms together into firm-industry-country fixed effects, $\psi_{f c i}$ and $\varphi_{f c i}$, and industry-year fixed effects, $\vartheta_{t i}$ and $\phi_{t i}$, yielding the following expressions.

$$
\begin{gathered}
\ln s_{t}(f)=\psi_{f c i}+\vartheta_{t i}+\gamma \ln m_{c t}(f) \\
\ln m_{c t}(f)=\varphi_{f c i}+\phi_{t i}+\zeta \ln s_{t}(f)-\nu \ln \tau_{c t i}
\end{gathered}
$$

Equations (8) and (9) form a set of linear simultaneous equations for parent and affiliate employment, making clear the inherent challenge in estimating $\gamma$, the effect of affiliate employment on parent employment ${ }^{21}$ Estimating (8) by OLS overstates the effect of affiliate employment on parent employment because of the simultaneity induced by (9), in which $\zeta>0.22$ However, (8) and (9) also provide a solution to the simultaneity problem. Reductions in effective tax rates on offshore activity, $\tau_{c t i}$, shift out the affiliate employment

\footnotetext{
${ }^{21}$ Given a Cobb-Douglas production function, $\gamma=\alpha_{i}\left(1-\eta_{i}\right) /\left(1-\alpha_{i} \eta_{i}\right)>0$. In Appendix B.2 we examine a more general model in which production is CES, and show that $\gamma$ can generally be positive or negative.

${ }^{22}$ The sign of additive simultaneity bias is given by the $\operatorname{sign}$ of $\zeta$ as long as the condition $\gamma \zeta<1$ is satisfied. This condition is necessary for the existence of equilibrium, and is satisfied in our context, since $0<\alpha_{i}, \eta_{i}<1$
} 
profile in (9), while leaving the parent profile in (8) unchanged. Therefore, when analyzing the effect of affiliate employment on multinational parent employment, we utilize a panel difference-in-differences research design based upon (8) in which we instrument for affiliate employment using BTTs.23

For this approach to succeed, $\tau_{c t i}$ must be excluded from the parent's best-response function. In Appendix B.1 we explicitly model BTT-induced reductions in withholding tax rates in the context of the U.S. corporate tax system. There, we show that if multinational parents insulate themselves from changes in double taxation by adjusting transfers between themselves and their affiliates, then the implementation of a new BTT satisfies the exclusion restriction. If instead new BTTs reduce the costs faced by both parents and affiliates, the IV estimates will not entirely resolve the simultaneity issue. In that case, some portion of the upward bias will remain, and our estimates will reflect an upper bound on the true effect of affiliate employment on domestic employment. As discussed below, our results are less than one third the magnitude of the most closely related estimates in the literature (Desai et al. 2009). Therefore, in spite of the potential theoretical concern regarding exclusion, our approach appears to substantially ameliorate the simultaneity issue in practice.

\subsubsection{Industry Labor Demand}

Total industry employment in the home country includes hiring for headquarters services $s_{t}$ across all firms, along with domestic labor used in assembly, $m_{t}$, either in-house or at arm's length. Let $O_{t i}$ be the set of firms in industry $i$ that choose to offshore assembly within an affiliate in a foreign country during period $t$, while $A_{t i}$ is the set of firms that source assembly services from an arms-length provider in a foreign country. Likewise let $I_{t i}$ denote the set of non-multinational firms that hire local workers in the home country to assemble output in-house, while $U_{t i}$ is the set of firms that source assembly from local arms-length providers in the home country. In total, domestic employment for industry $i$ is given by

$$
\begin{aligned}
L_{t i} \equiv \int_{f \in O_{t i} \subset F_{t i}} s_{t}(f) d f+ & \int_{f \in A_{t i} \subset F_{t i}} s_{t}(f) d f \\
& +\int_{f \in I_{t i} \subset F_{t i}}\left[m_{c t}(f)+s_{t}(f)\right] d f+\int_{f \in U_{t i} \subset F_{t i}}\left[m_{c t}(f)+s_{t}(f)\right] d f .
\end{aligned}
$$

Equation (10) shows that a decline in the effective cost of offshore activity resulting

\footnotetext{
${ }^{23}$ An alternative approach to our empirical strategy is to exploit the variation in the changes in individual tax rates across countries shown in Table 1. We prefer the binary treatment indicator as it is the most conservative and transparent approach, but the results (available in Appendix A.4) are unaffected when we scale the BTT indicator according to country-specific changes in withholding tax rates.
} 
from a BTT $\left(d \tau_{c t i}<0\right)$ may affect total industry employment, $L_{t i}$, in a variety of ways. First, existing integrated multinational firms $\left(O_{t i}\right)$ will increase offshore employment with the decline in its effective cost, and this change will affect headquarters employment based on $\gamma$ in (9). Based on the positive reduced-form results for continuing multinational firms discussed in Section 3, this intensive margin effect is likely to increase domestic employment. Other firms will change organizational form to become new integrated multinationals. If these firms had previously assembled goods domestically $\left(I_{t i}\right.$ or $\left.U_{t i}\right)$, this extensive margin shift will lower domestic employment (Boehm et al. 2017). We therefore expect to find more negative (less positive) domestic employment effects of increased offshore activity among firms opening new affiliates in BTT countries than among firms maintaining continuing affiliates. Finally, because the costs of production for integrated multinationals fall, other firms face stiffer competition in product markets and may contract as a result (Groizard et al. 2015). Given the various positive and negative components, the overall effect on industry employment may be positive or negative. We therefore empirically examine both the overall effect on industry employment along with separate effects for existing multinationals, for firms opening new affiliates in BTT countries, and for non-multinationals, confirming the heterogeneity in effects just described.

\subsection{Empirical Analysis}

\subsubsection{The Effect of BTTs on Foreign Affiliate Employment}

Solving the system in (9) and (8) yields a first-stage estimating equation the effect of BTTs on foreign affiliate employment:

$$
\ln m_{a t}=\beta^{A} B T T_{c t}+\Gamma X_{a t}+\mathrm{a}_{a}+b_{t i}+\epsilon_{a t} .
$$

Affiliates are defined by thier parent $f$, in country $c$, and industry $i$, which we consolidate one subscript $a$ indicating an individual affiliate. ${ }^{24}$ The term $m_{a t}$ is employment for affiliate $a, B T T_{c t}$ is an indicator for the presence of a BTT between the U.S. and affiliate country $c$ in year $t$, and $X_{a t}$ is a vector of controls. Affiliate and industry-year fixed effects are given by $\mathrm{a}_{a}$ and $b_{t i}$, respectively, and $\epsilon_{a t}$ is an error term. We two-way cluster standard errors by affiliate country and by year. The coefficient of interest is $\beta^{A}$, reflecting the difference in employment growth for affiliates in the same industry, located in countries that do and do not receive BTTs during our sample period. BTTs lower the effective cost of offshore

\footnotetext{
${ }^{24}$ The BEA survey allows firms the option of aggregating sibling affiliates in the same industry and country when reporting, so we apply this aggregation to all firms for consistency.
} 
activity for MNEs, so we expect $\hat{\beta}^{A}>0$ with effects appearing primarily in industries with high royalty, interest, and dividend (RID) payments from foreign affiliates to parent firms.

Table 4 reports the results of estimating (11). In column (1), we include all affiliates and find a positive and statistically significant point estimate, indicating that affiliates in countries receiving a BTT expanded their employment more than other affiliates in the same industry. Columns (2) and (3) show that this positive effect is entirely driven by affiliates in high RID industries, where BTTs are most likely to resolve double taxation. The effect in low RID industries in column (3) is statistically indistinguishable from zero and is economically small. Columns (4) - (6) introduce the standard controls discussed in Section 2, along with controls for BTTs in sibling affiliate countries to control for potential spillovers across siblings. We define "Parent-Sibling BTTs" as the share of initial sibling affiliate employment covered by a BTT with the U.S. in year $t$ and "Affiliate-Sibling BTT" as the share of initial sibling affiliate employment covered by a BTT between country $c$ and the countries in which affiliate $a$ has siblings. In both cases, using the initial shares of employment observed for each firm avoids allowing endogenous shifts in the affiliate weights to affect these controls. These controls have minimal effects on the coefficients of interest. The coefficient estimate of 0.338 in column (5) indicates that in high RID industries, receiving a BTT increased affiliate employment by 40.2 percent, on average.25

The results in Table 4 imply that BTTs substantially increase affiliate employment by resolving double taxation, thereby lowering the effective tax rate on affiliate activity. This effect is only present in high RID industries in which double taxation is most prevalent. Specification (11) represents the first stage of the instrumental-variables analysis in the following sections, and the first-stage partial F-statistics are large enough to rule out weak instruments concerns only in high RID industries. ${ }^{26}$ This means that BTTs provide a policy experiment for evaluating the effects of foreign affiliate employment on domestic employment, but only in industries with high royalties, interest, and dividends. For this reason, we focus on high RID industries in the instrumental-variables analyses in the following sections. We also note that for the subsample of low RID industries in which we have no first-stage relationship in Table 4, we also have no reduced-form relationship in Table 3 . The fact that the reduced-form relationship is absent precisely when the first-stage relationship is absent helps rule out potential concerns regarding violations of the exclusion restriction when using BTTs as an instrument for foreign affiliate employment (Angrist and Pischke (2009) p.131).

\footnotetext{
${ }^{25} 100 *(\exp (0.338)-1)=40.2$

${ }^{26}$ Stock and Yogo (2005) report that in order to reject the null hypothesis that the actual size of a 5 percent test is greater than 10 percent, the first stage $\mathrm{F}$ statistic must be greater than 16.38 in columns (1)-(3) 22.30 in columns (4)-(6).
} 


\subsubsection{The Effect of Offshoring on Multinational Firm Employment}

We now utilize BTT-induced variation in foreign affiliate employment to measure its effect on domestic employment within U.S. multinational firms. Our objective is to estimate the following parent-level specification corresponding to equation (8).

$$
\ln s_{f t}=\beta^{P} \ln M_{f t}+\Gamma X_{f t}+c_{f}+d_{t i}+\epsilon_{f t},
$$

where $s_{f t}$ is parent employment and $M_{f t} \equiv \sum_{a \in f} m_{a t}$ is total affiliate employment for firm $f{ }^{27} X_{f t}$ is a vector of parent-level controls (described below), and $c_{f}$ and $d_{t i}$ are firm and industry-year fixed effects. We two-way cluster standard errors by parent and by year. The coefficient of interest, $\beta^{P}$, may be positive or negative, depending upon whether scale effects or substitution effects dominate.

Because many parent firms have multiple affiliates, and the first-stage regression in (11) is at the affiliate level, we must aggregate the first-stage predicted values for affiliate employment up to the parent level. Aggregating the predicted values for $\ln m_{a t}$ to predict $\ln M_{f t}$ involves a nonlinear transformation of random variables, and we perform the aggregation accounting for the sampling distribution of the affiliate-level predicted values ${ }^{28}$ This nonlinearity also implies that simply plugging the estimate $\widehat{\ln M_{f t}}$ into the second-stage regression in 12 is inappropriate. This would be an example of the so-called "forbidden regression" in which a nonlinear first-stage estimate is plugged into a linear second stage (Wooldridge, 2002; Angrist and Pischke, 2009). We follow Wooldridge (2002) Procedure 18.1, estimating an IV regression for 12 , with the predicted $\widehat{\ln M_{f t}}$ as an instrument for the observed $\ln M_{f t} .^{29}$ We must similarly aggregate the controls, $X_{a t}$ in (11), from the affiliate to the parent level. We generate employment-weighted averages of the affiliate-level controls, using affiliate employment weights from the year before the parent's first affiliate receives a BTT $\left(\tilde{t}_{f}-1\right)$.

Table 5 presents OLS and IV estimates of (12), measuring how changes in foreign affiliate employment affect employment at U.S. parent firms. Table 5 reports the first-stage partial Fstatistics associated with Wooldridge (2002) Procedure 18.1, but the appropriate F-statistics to consider when evaluating weak instruments concerns are those for the affiliate-level first

\footnotetext{
${ }^{27}$ Recent work by Antràs et al. (2017) argues that the number of affiliates comprising a parent firm's total offshore employment likely influences the effects of offshore activity on parent firm productivity, which can subsequently impact the employment effects we estimate here. We are abstracting from this mechanism.

${ }^{28}$ This procedure is known as "smearing" and addresses issues similar to Jensen's inequality. Our main results use a parametric smearing approach assuming normally distributed errors (see Appendix B.3), but a nonparametric version based on Duan (1983) and a naive plug-in estimate both yield similar results.

${ }^{29}$ Note that the parent-level IV standard errors are accurate in spite of the affiliate-level instrument generation procedure that precedes it (Wooldridge, 2002).
} 
stage in Table 4$]^{30}$ Because we only have a strong first-stage relationship between BTTs and foreign affiliate employment within certain industries, we restrict our sample of parents in Table 5 to those in high RID industries.

Columns (1) and (2) of Table 5 implement naive OLS regressions of domestic parent employment on total foreign affiliate employment. The very large positive correlation between parent and affiliate employment likely reflects upward simultaneity bias, as discussed in Section 4.1.3. The IV results in columns (3) and (4) confirm this point, finding much smaller point estimates and rejecting the equality of OLS and IV results at conventional levels. The IV coefficient on $\ln M_{f t}$ in column (4) is positive and statistically significant, suggesting that a 10 percent increase in foreign affiliate employment drives a 1.3 percent increase in domestic employment at the U.S. parent firm. As shown in column (5) of Table 4 , a new BTT increases employment at affected affiliates in highly RID industries by approximately 40.2 percent. Using the estimate from column (4) of Table 5, this corresponds to about a 5.2 percent increase in domestic employment, or about 413 new U.S. workers for the average parent firm. The coefficients of interest in columns (3) and (4) are quite similar, indicating that our results are robust to including or excluding the controls, $X_{f t}$.

As mentioned in Section 4.1.3, our instrumental variables strategy requires that BTTs shift affiliates' best response functions while leaving those of parents unchanged. If this assumption is violated, then the IV results in Table 5 may retain some upward bias. Yet, even in that case, the estimates remain informative. First, the IV estimates in columns (3) and (4) are significantly smaller than the OLS estimates in columns (1) and (2), implying that our IV strategy is substantively addressing the simultaneity between parent and affiliate employment. Second, the most closely related result in the prior literature is found in Desai et al. (2009), which reports an effect that is 5 times larger than our estimates in column (4) of Table 5 [1 $^{31}$ Our estimates reflect an upper bound on the true effect of affiliate employment on parent employment, yet they are significantly below the OLS estimates and imply a much less positive effect than one would expect based upon prior work.

As discussed in Section 4.1.4, we expect the expansion of existing affiliates to increase domestic employment because parent firms benefit from scale effects when the effective cost of their offshore activity falls with a BTT. However, extensive margin effects, in which firms shift activity from domestic to offshore locations, may decrease domestic employment within the U.S. parent firm. Although we cannot observe employment for newly formed multinational firms before they begin offshoring, we can examine effects for continuing multinationals that open or acquire new affiliates in BTT countries during our sample period. We expect the

\footnotetext{
${ }^{30}$ Large F-statistics are common when implementing Wooldridge (2002) Procedure 18.1.

${ }^{31}$ See Table 5, column (4) in Desai et al. (2009).
} 
domestic employment growth to be less positive for these firms exhibiting extensive margin offshoring. This is precisely what we find in columns (5) and (6) of Table 5 . When restricting attention to multinationals opening new affiliates in BTT countries (column (5)), the effect on domestic employment is not statistically significant, while larger statistically significant effects appear for multinationals that exhibit only intensive margin behavior (column (6)).

\subsubsection{Industry Level Effects of Offshoring}

We now address the employment effects of offshoring on overall industry employment in the U.S. This broader analysis allows us to capture two margins that are absent when examining multinational firms alone. First, the changes in employment at multinational parents may be partly offset by equilibrium employment adjustment at other domestic firms in the industry. Second, declining costs of offshore activity will likely motivate some firms to become multinational firms by opening new affiliates. Both of these margins contribute to industry-level employment responses. We measure U.S. industry employment using County Business Patterns data at the 3-digit SIC level and link to the BEA International Surveys Industry (ISI) classification, resulting in 61 consistently identifiable high-RID industries. Even though we only consider industries with high royalty, interest, and dividend payments, these industries employ an average of about 111 million U.S. workers annually in our sample.

We study the relationship between log domestic employment and log total affiliate employment at the industry level using the following specification.

$$
\ln L_{i t}=\beta^{I} \ln M_{i t}+\Gamma X_{i t}+f_{i}+g_{t}+\epsilon_{i t}
$$

where $L_{i t}$ is total domestic employment in industry $i$ in year $t, M_{i t}$ is total foreign affiliate employment in the industry, and $f_{i}$ and $g_{t}$ are industry and year fixed effects. We calculate two-way clustered standard errors by industry and year. As with the parent-level regressions, we aggregate from the affiliate level to the industry level, taking care to address the nonlinearity of the aggregation. We then instrument for observed log industry affiliate

employment $\ln M_{i t}$, using predicted log industry affiliate employment $\widehat{\ln M_{i t}}$. Because the increases in employment within continuing multinational firms may be partly or entirely offset by reductions in employment at newly offshoring firms or competing domestic firms, the estimate of $\beta^{I}$ may be positive or negative.

Table 6 shows the relationship between U.S. employment and offshore affiliate employment at the industry level. Columns (1) and (2) present the OLS results, and columns (3) and (4) show the instrumental variables results. As in the multinational parent-level analysis, the estimates are positive, implying that the various margins just discussed combine to yield 
modest increases in domestic industry employment when affiliates of multinational firms in that industry experience BTT-induced reductions in the cost of foreign affiliate activity. The IV estimates are approximately half the size of the corresponding the OLS estimates, confirming the importance of appropriately addressing the simultaneity issue. The IV estimates are small in magnitude and significant at the 5 percent level, suggesting that the negative effects from equilibrium adjustments to employment and any offshoring by new multinationals at the industry level offset much, but not all, of the gains in domestic employment within existing multinationals.

We observe total multinational employment in the BEA data, and then calculate nonmultinational employment as a residual, subtracting multinational employment from total industry employment measured using County Business Patterns data. Table 7 columns (1) and (2) show that domestic employment in multinational firms increases in response to growth in affiliate employment. This is simply the industry-level analogue of the parent-level effect in Table 5. In contrast, the effects on industry-level non-multinational employment in columns (3) and (4) are extremely small and statistically indistinguishable from zero, implying that non-multinational firms do not share in the employment growth of multinational firms when the costs of offshore employment fall.

Table 8 adds additional nuance to these findings by considering the effects of increased foreign affiliate employment only for vertically oriented foreign affiliates-those with sales to their U.S. parent firm. ${ }^{32}$ We expect increased activity at vertically oriented affiliates to have more negative effects on domestic employment, since their activities are more likely to replace those of domestic suppliers of intermediate inputs. The effects on domestic employment in multinational firms, shown in columns (1) and (2), remains positive and statistically significant. However, increases in foreign affiliate employment among vertically oriented affiliates drive decreases in domestic employment among non-multinational firms in the same industry. Although small, these employment decreases likely reflect a combination of shifts in sourcing away from domestic suppliers and competition from multinational firms enjoying decreased costs of affiliate activity following the implementation of a BTT.

\subsubsection{Regional Effects of Offshoring}

Finally, we measure the domestic employment effects of offshoring at the regional level. This perspective adds yet another margin of labor market adjustment to the analysis by including potential employment spillovers across industries in the same region. Our unit of

\footnotetext{
${ }^{32}$ Tables 7 and 8 show the only case in which the results for vertical affiliates qualitatively differ from those for all affiliates. Appendix A.5 reports all other results in the paper, restricting attention to vertically oriented foreign affiliates.
} 
analysis is the metropolitan area, and we use 304 time-consistent metro areas, constructed from underlying county-level employment in the County Business Patterns data ${ }^{33}$ Our metro-area estimation equation is

$$
\ln L_{m t}=\beta^{M} \ln M_{m t}+h_{m}+k_{t}+\epsilon_{m t},
$$

where $L_{m t}$ is metro area $m$ employment in year $t$, and $h_{m}$ and $k_{t}$ are metro area and year fixed effects. Standard errors are two-way clustered by metro area and year. Our regional measure of offshoring exposure, $M_{m t}$ is a weighted average of industry-level foreign affiliate employment. We construct industry-level foreign affiliate employment as described above, and the industry weights reflect the distribution of employment across covered industries in 1986, just before the start of our main analysis sample: $M_{m t} \equiv \sum_{i} \sigma_{m i}^{1986} M_{i t}$ where $\sigma_{m i}^{1986} \equiv$ $L_{m i}^{1986} / \sum_{i^{\prime}} L_{m i^{\prime}}^{1986}$. This measure captures each metro area $m$ 's exposure to foreign affiliate employment, following a procedure similar to Topalova (2010), Autor et al. (2013), Kovak (2013), and others. We generate an instrument for $\ln M_{m t}$ by constructing an otherwise identical measure that replaces observed industry affiliate employment, $M_{i t}$, with predicted industry affiliate employment, $\widehat{M_{i t}}$, as in the industry-level analysis.

Table 9 shows the region-level results, with OLS estimates in columns (1) and (2) and IV estimates in columns (3) and (4). As with the aggregate industry-level results, the relationship between offshoring and employment is positive, and the IV estimates are smaller than the OLS results. The estimate in column (4) implies that a metro area whose industries experience on average a 10 percent increase in affiliate employment exhibit a 0.17 percent increase in metro area employment. While this is a modest positive effect, it is larger in magnitude than the industry-level results in Table 6, suggesting the possibility of crossindustry spillovers between industries directly affected by offshoring and other industries in the region that are indirectly affected by changes in local economic conditions.

\section{Conclusion}

The consequences of ever rising levels of offshoring activity by U.S. multinational firms are consistently a source of debate for both the public and policy makers. However, among other challenges, the fact that offshore hiring and domestic employment are determined simultaneously has made it difficult for economists to provide clear answers about the relationship between the two. We contribute to this discussion by providing estimates that

\footnotetext{
${ }^{33}$ In order to maintain confidentiality, in small counties the CBP data report employment ranges rather than precise employment counts. Appendix A.6 describes our approach to imputing these values and presents similar results treating suppressed values as zeros.
} 
rely on relevant and exogenous variation in offshoring costs, allowing us to infer the causal implications of greater offshore employment for U.S. labor market outcomes. We provide clear evidence that changes in the global tax structure influence the hiring activity of U.S. multinational firms both domestically and abroad, with spillover effects to regional U.S. employment outcomes. These changes in hiring activity demonstrate how shifts in global tax structure can alter the geographic distribution of economic activity both across and within national borders.

Our results also highlight important nuances in the effects of various international economic activities, demonstrating that the effects of offshoring differ across firms' organizational structures and across different margins of offshoring activities. Within existing multinationals, a fall in the cost of offshoring has a net positive effect on U.S. hiring. However, when the costs of offshore activity fall, some firms may alter their global sourcing strategies and begin to substitute offshore facilities for activities that had previously been completed locally. This substitution can adversely affect employment outcomes for U.S. workers. Among multinational firms that open new affiliates in countries that realize lower offshoring costs, we find that domestic employment responds only modestly to BTTs, suggesting that positive scale effects are largely offset by negative substitution effects in these firms. 


\section{References}

Joshua D. Angrist and Jörn-Steffen Pischke. Mostly Harmless Econometrics: An Empiricist's Companion. Princeton University Press, Princeton, NJ, 2009.

Pol Antràs and Elhanan Helpman. Global sourcing. Journal of Political Economy, 112(3): 552-580, 2004.

Pol Antràs, Teresa Fort, and Felix Tintelnot. The margins of global sourcing: Theory and evidence from u.s. firms. American Economic Review, 107(9):2514-2564, 2017.

David Autor, David Dorn, and Gordon Hanson. The china syndrome: Local labor market effects of import competition in the united states. American Economic Review, 103(6): 2121-2168, 2013.

Robert J. Barro and Jong-Wha Lee. A new data set of educational attainment in the world, 1950-2010. NBER working paper 15902, 2010.

Marianne Bertrand, Esther Duflo, and Sendhil Mullainathan. How much should we trust differences-in-differences estimates? The Quarterly Journal of Economics, pages 249-275, 2004.

Bruce A. Blonigen and Ronald B. Davies. The effects of bilateral tax treaties on u.s. fdi activity. International Tax and Public Finance, 11:601-622, 2004.

Bruce A. Blonigen and Ronald B. Davies. Do bilateral tax treaties promote foreign direct investment. In James Hartigan, editor, Handbook of International Trade Volume II: Economic and Legal Analysis of Laws and Institutions. Blackwell Publishing Ltd, 2005.

Bruce A. Blonigen, Lindsay Oldenski, and Nicholas Sly. The differential effects of bilateral tax treaties. American Economic Journal: Economic Policy, 6(2):1-18, 2014. NBER working paper 17480 .

Christoph E. Boehm, Aaron Flaaen, and Nitya Pandalai-Nayar. Multinationals, offshoring and the decline of u.s. manufacturing. mimeo, 2017.

S Lael Brainard and David A Riker. Are us multinationals exporting us jobs? Technical report, National Bureau of Economic Research, 1997.

David L. Carr, James R. Markusen, and Keith E. Maskus. Testing the knowledge-capital model of the multinational enterprise. The American Economic Review, 91(3):995-1001, 2001.

Ronald B. Davies. Tax treaties and foreign direct investment: potential versus performance. International Tax and Public Finance, 11:775-802, 2004.

Ronald B. Davies, Pehr-Johan Norback, and Ayca Tekin-Koru. The effect of tax treaties on multinational firms: new evidence from micro-data. The World Economy, 32(1):77-110, 2009. 
Fabrice Defever and Farid Toubal. Productivity, relationship-specific inputs and the sourcing modes on multinationals. Journal of Economic Behavior and Organization, 94:345-57, 2013.

Mihir A. Desai, C. Fritz Foley, and James R. Hines. Repatriation taxes and dividend distortions. National Tax Journal, 54(4):829-851, 2001.

Mihir A Desai, C Fritz Foley, and James R Hines. Domestic effects of the foreign activities of us multinationals. American Economic Journal: Economic Policy, 1(1):181-203, 2009.

Julian di Giovanni. What drives capital flows? the case of cross-border m\&a activity and financial deepening. Journal of International Economics, 65(1):127-149, 2005.

Richard L. Doernberg. International Taxation in a Nutshell. West Academic Publishing, 10th edition edition, 2016.

Naihua Duan. Smearing estimate: A nonparametric retransformation method. Journal of the American Statistical Association, 78(383):605-610, 1983.

Peter Egger, Mario Larch, Michael Pfaffermayr, and Hannes Winner. The impact of endogenous tax treaties on foreign direct investment: Theory and empirical evidence. Canadian Journal of Economics, 39(3):901-931, 2006.

Ernst and Young. International tax alert: News from transfer pricing. 2015.

Robert C Feenstra and Gordon H Hanson. Ownership and control in outsourcing to china: Estimating the property-rights theory of the firm. Quarterly Journal of Economics, (2): 729-761, 2005.

Jose L. Groizard, Priya Ranjan, and Antonio Rodriguez-Lopez. Trade costs and job flows: evidence from establishment-level data. Economic Inquiry, 53(1):173-204, 2015.

Ann Harrison and Margaret McMillan. Offshoring jobs? multinationals and us manufacturing employment. Review of Economics and Statistics, 93(3):857-875, 2011.

David Hummels, Rasmus Jørgensen, Jakob Munch, and Chong Xiang. The wage effects of offshoring: Evidence from danish matched worker-firm data. The American Economic Review, 104(6):1597-1629, 2014.

Louis S Jacobson, Robert John LaLonde, and Daniel Gerard Sullivan. Earnings losses of displaced workers. The American Economic Review, 83:685-709, 1993.

Brian Kovak. Regional efects of trade reform: What is the correct measure of liberalization? American Economic Review, 103(5):1960-1976, 2013.

Henry J. Louie and Donald J. Rousslang. Host-country governance, tax treaties and us direct investment abroad. International Tax and Public Finance, 15(3):256-273, 2008.

Jr. Misey, Robert J. and Michael S. Schadewald. Practical Guide to U.S. Taxation of International Transactions. Wolters Kluwer, 10th edition edition, 2015. 
Ryan Monarch, Jooyoun Park, and Jagadeesh Sivadasan. Gains from offshoring? evidence from u.s. microdata. University of Michigan, 2014.

Marc-Andreas Muendler and Sascha O. Becker. Margins of multinational labor substitution. The American Economic Review, 100(5):1999-2030, 2010.

Gianmarco I.P. Ottaviano, Giovanni Peri, and Greg C. Wright. Immigration, offshoring and american jobs. American Economic Review, 103(5), 2013.

Matthew J. Slaughter. Production transfer within multinational enterprises and american wages. Journal of International Economics, 50(2), 2000.

Matthew J. Slaughter. International trade and labor-demand elasticities. Journal of International Economics, 54(1):27-56, 2001.

Matthew J. Slaughter. How u.s. multinational companies strengthen the u.s. economy. Technical report, Business Roundtable and Business Roundtable and The United States Council Foundation, 2009.

James H Stock and Motohiro Yogo. Testing for weak instruments in linear iv regression. In Donald W. K. Andrews and James H. Stock, editors, Identification and Inference for Econometric Models: Essays in Honor of Thomas Rothenberg, pages 80-108. Cambridge University Press, 2005.

Juan Carlos Suárez Serrato. Unintended consequences of eliminating tax havens. mimeo, 2018.

Petia Topalova. Factor immobility and regional impacts of trade liberalization: Evidence on poverty from india. American Economic Journal: Applied Economics, 2(4), 2010.

Jeffrey M. Wooldridge. Econometric Analysis of Cross Section and Panel Data. MIT Press, Cambridge, MA, 2002. 
Figure 1: Effect of BTTs on U.S. Multinational Firm Employment in High Royalty, Interest and Dividend Industries

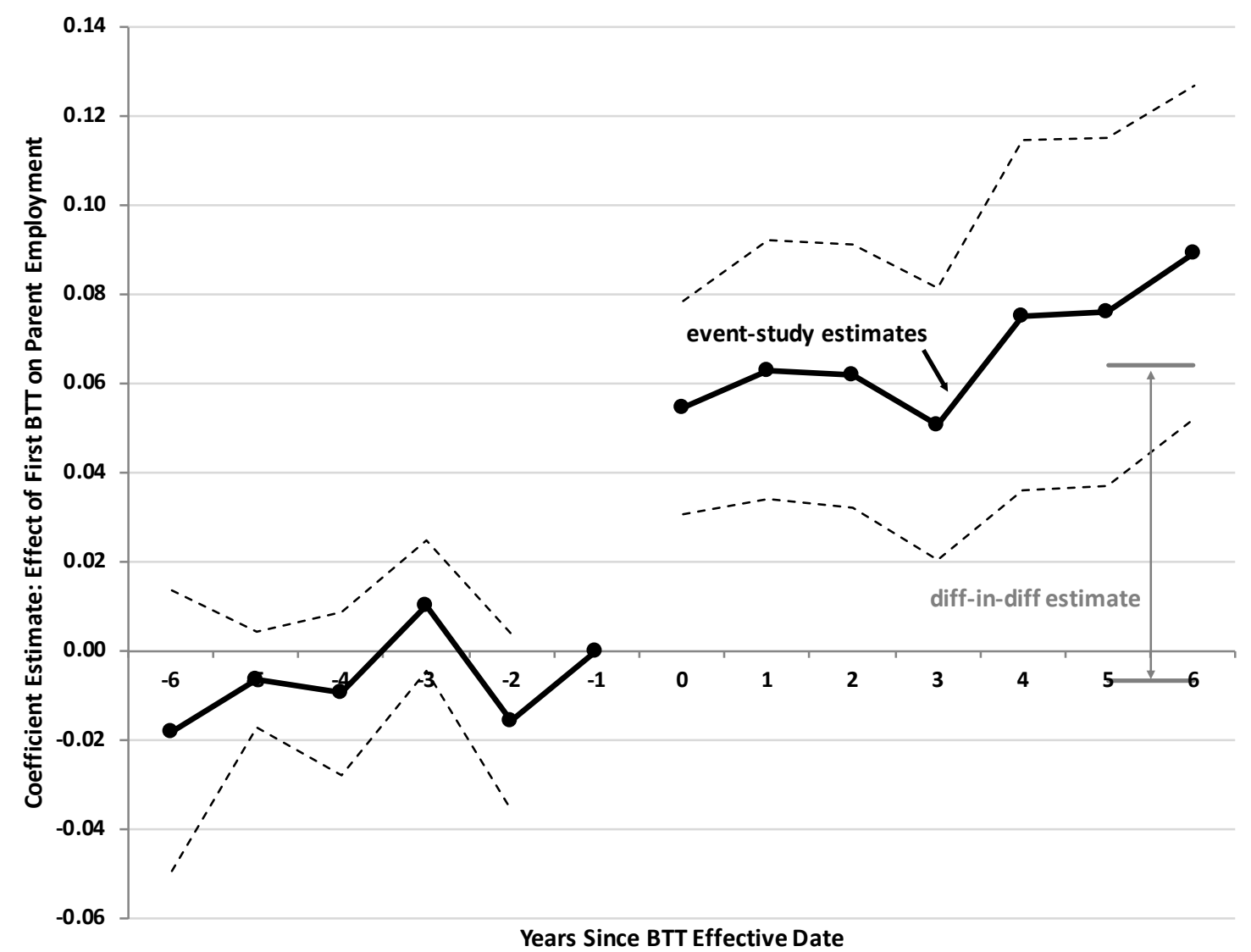

Source: Authors' calculations based on BEA Annual Surveys of U.S. Direct Investment Abroad 1987-2007. Sample restricted to firms in industries with high RID payments to U.S. parent firms. Each point on the black line represents a coefficient estimate from the event study specification in 22. Dashed lines reflect 95 percent confidence intervals for these event-study estimates when clustering standard errors by both parent firm and year. Gray lines reflects the diff-in-diff estimate described in 1, located so the lower line corresponds to the average of pre-BTT event study coefficients. Both specifications include firm and industry $\times$ time fixed effects and a full set of controls, as in column (5) of Table 3 


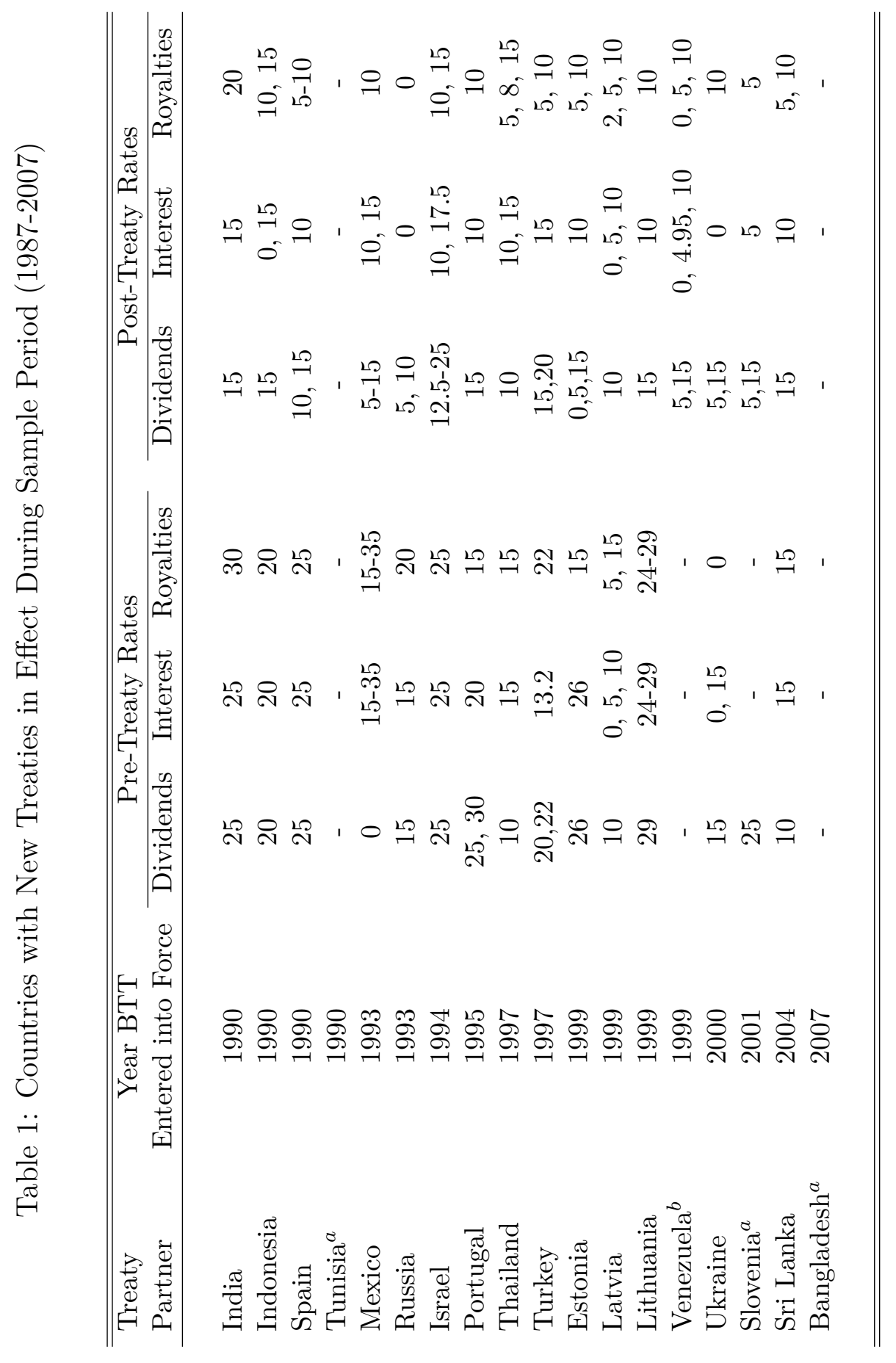

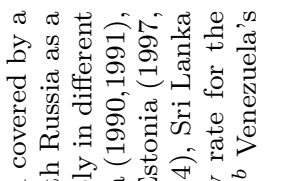

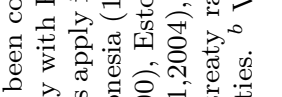

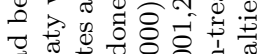

త్ర

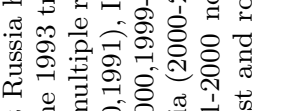

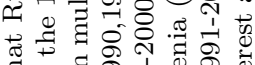

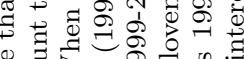

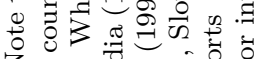

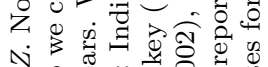

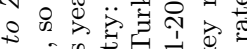

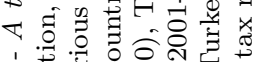

今.

志

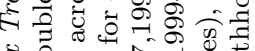

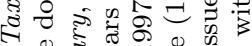

\&

है

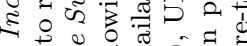

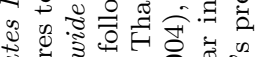

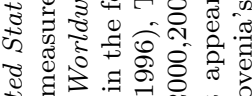

今ं

党

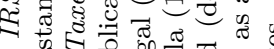

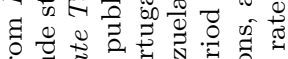

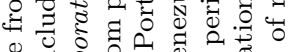

。

สँ

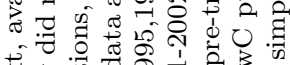

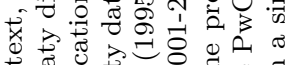

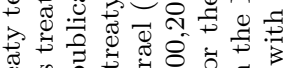

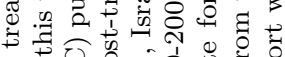

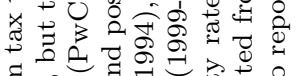

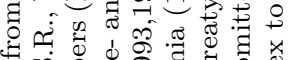

出

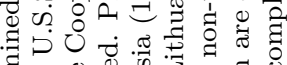

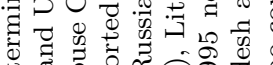

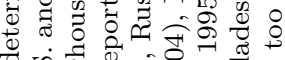

o ?

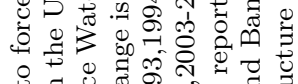

苟范苛

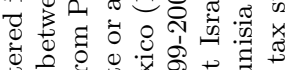

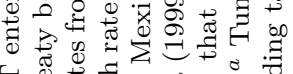

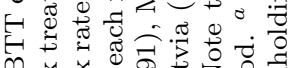

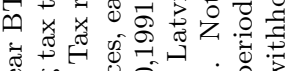

式

\%ิ

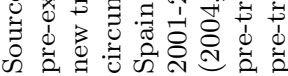


Table 2: Summary Statistics.

\begin{tabular}{|c|c|c|c|c|}
\hline & Mean & Std. Dev. & Min & $\operatorname{Max}$ \\
\hline \multicolumn{5}{|c|}{ FOREIGN AFFILIATES (342,239 obs.) } \\
\hline Employment & 474.30 & 2394.8 & \multicolumn{2}{|c|}{ (confidential) } \\
\hline $\ln ($ Employment $)$ & 4.3788 & 1.9213 & \multicolumn{2}{|c|}{ (confidential) } \\
\hline Av. Annual Emp Growth (\%) & 0.0909 & 0.7876 & \multicolumn{2}{|c|}{ (confidential) } \\
\hline BTT & 0.8099 & 0.3924 & 0 & 1 \\
\hline High RID Indicator & 0.5763 & 0.4941 & 0 & 1 \\
\hline $\ln \left(G D P_{u s}+G D P_{d}\right)$ & 9.3112 & 0.2040 & 8.8665 & 10.093 \\
\hline $\ln \left(G D P_{u s}-G D P_{d}\right)^{2}$ & 18.184 & 0.4946 & 14.841 & 18.933 \\
\hline $\ln ($ Skill Difference) & 1.0984 & 0.7194 & 0 & 2.494 \\
\hline $\ln ($ Trade Cost $)$ & 2.6727 & 2.3737 & 0 & 4.5940 \\
\hline BIT & 0.0516 & 0.2212 & 0 & 1 \\
\hline FTA & 0.1216 & 0.3269 & 0 & 1 \\
\hline Exchange Rate & 140.50 & 819.37 & 0 & 16105 \\
\hline Parent-Sibling BTTs ${ }^{a}$ & 0.5645 & 0.2053 & 0 & 1 \\
\hline Affiliate-Sibling BTTs ${ }^{b}$ & 0.2944 & 0.3888 & 0 & 1 \\
\hline \multicolumn{5}{|l|}{ U.S. PARENT FIRMS (43,233 obs.) } \\
\hline Foreign Affiliate Employment & 3513.2 & 16010 & \multicolumn{2}{|c|}{ (confidential) } \\
\hline $\ln ($ Aff Emp $)$ & 5.6966 & 2.3485 & \multicolumn{2}{|c|}{ (confidential) } \\
\hline Av Annual Aff Emp Growth (\%) & 0.1090 & 0.7911 & \multicolumn{2}{|c|}{ (confidential) } \\
\hline Parent Firm Employment & 7906.7 & 28649 & \multicolumn{2}{|c|}{ (confidential) } \\
\hline $\ln ($ Parent Emp) & 7.2009 & 2.0656 & \multicolumn{2}{|c|}{ (confidential) } \\
\hline Number of Affiliates & 8.6924 & 18.445 & \multicolumn{2}{|c|}{ (confidential) } \\
\hline $\ln \left(G D P_{u s}+G D P_{d}\right)^{c}$ & 4.5246 & 3.610 & 0 & 29.618 \\
\hline $\ln \left(G D P_{u s}-G D P_{d}\right)^{2 c}$ & 8.8243 & 7.0513 & 0 & 58.087 \\
\hline $\ln (\text { Skill Difference })^{c}$ & 0.4759 & 0.5094 & 0 & 4.240 \\
\hline $\ln (\text { Trade Cost })^{c}$ & 1.4748 & 1.6564 & 0 & 10.940 \\
\hline $\mathrm{BIT}^{c}$ & 0.0178 & 0.0717 & 0 & 1 \\
\hline $\mathrm{FTA}^{c}$ & 0.1538 & 0.3261 & 0 & 1 \\
\hline Exchange Rate $^{c}$ & 21.485 & 217.81 & 0 & 23573 \\
\hline
\end{tabular}

Authors' calculations from BEA Annual Surveys of U.S. Direct Investment Abroad 1987-2007 and various other data sources, described in Section 2, ${ }^{a}$ Weighted average share of total sibling employment covered by a BTT with the U.S., using fixed affiliate employment shares. ${ }^{b}$ Weighted average share of total sibling employment covered by a BTT with the affiliate's country, using fixed affiliate employment shares. ${ }^{c}$ Parent-level versions of affiliate country controls are aggregated from the country to the parent firm level using a weighted average, using fixed affiliate employment shares as weights. 
Table 3: Reduced Form Difference-in-Differences Analysis:

The Effect of BTTs on Parent Employment

Dependent variable: $\log$ parent employment: $\ln \left(s_{f t}\right)$

\begin{tabular}{|c|c|c|c|c|c|c|}
\hline Sample: & $\begin{array}{l}(1) \\
\text { All } \\
\end{array}$ & $\begin{array}{c}(2) \\
\text { High RID }\end{array}$ & $\begin{array}{c}(3) \\
\text { Low RID }\end{array}$ & $\begin{array}{l}(4) \\
\text { All } \\
\end{array}$ & $\begin{array}{c}(5) \\
\text { High RID }\end{array}$ & $\begin{array}{c}(6) \\
\text { Low RID }\end{array}$ \\
\hline \multirow{2}{*}{$\operatorname{BTT}\left[\tilde{\varphi}_{f} \mathbf{1}\left(t \geq \tilde{t}_{f}\right)\right]$} & 0.027 & $0.055^{* * *}$ & -0.009 & 0.012 & $0.064^{* * *}$ & -0.027 \\
\hline & $(0.007)$ & $(0.014)$ & $(0.013)$ & $(0.090)$ & $(0.023)$ & $(0.018)$ \\
\hline \multirow[t]{2}{*}{$\ln \left(G D P_{u s}+G D P_{d}\right)$} & & & & 0.025 & -0.076 & 0.196 \\
\hline & & & & $(0.123)$ & $(0.147)$ & $(0.189)$ \\
\hline \multirow{2}{*}{$\ln \left(G D P_{u s}-G D P_{d}\right)^{2}$} & & & & -0.054 & -0.006 & -0.135 \\
\hline & & & & $(0.061)$ & $(0.072)$ & $(0.094)$ \\
\hline \multirow[t]{2}{*}{$\ln ($ Skill Difference) } & & & & -0.077 & -0.084 & -0.066 \\
\hline & & & & $(0.050)$ & $(0.059)$ & $(0.095)$ \\
\hline \multirow[t]{2}{*}{$\ln ($ Trade Costs $)$} & & & & 0.003 & 0.012 & 0.003 \\
\hline & & & & $(0.015)$ & $(0.017)$ & $(0.030)$ \\
\hline \multirow[t]{2}{*}{$\mathrm{BIT}$} & & & & -0.287 & -0.242 & -0.259 \\
\hline & & & & $(0.177)$ & $(0.244)$ & $(0.23)$ \\
\hline \multirow[t]{2}{*}{ FTA } & & & & -0.008 & -0.08 & 0.02 \\
\hline & & & & $(0.062)$ & $(0.088)$ & $(0.079)$ \\
\hline \multirow[t]{2}{*}{ Exchange Rate } & & & & -0.0001 & -0.0001 & 0.0001 \\
\hline & & & & $(0.000)$ & $(0.000)$ & $(0.000)$ \\
\hline Parent FE & YES & YES & YES & YES & YES & YES \\
\hline Industry-Year FE & YES & YES & YES & YES & YES & YES \\
\hline $\mathrm{N}$ & 43233 & 29765 & 13468 & 43233 & 29765 & 13468 \\
\hline R-sq & 0.0021 & 0.0033 & 0.0002 & 0.0573 & 0.0644 & 0.0431 \\
\hline
\end{tabular}

Notes: Documents the effects of newly signed bilateral tax treaties (BTTs) on parent employment at multinational firms. "High RID" and "Low RID" refer to firms within industries that exhibit ratios of total payments in royalties, interest, and dividends relative to total industry sales that are above and below the median sector (see Appendix A.2 for details). Sample covers 1987-2007. Standard errors clustered by both parent firm and year are in parentheses. $*, * *$, and $* * *$ indicate significance at the 10,5 , and 1 percent levels, respectively. 
Table 4: Foreign Affiliate-Level Analysis:

The Effect of BTTs on Offshore Employment

Dependent variable: $\log$ affiliate employment: $\ln \left(m_{a t}\right)$

\begin{tabular}{|c|c|c|c|c|c|c|}
\hline Sample: & $\begin{array}{l}(1) \\
\text { All }\end{array}$ & $\begin{array}{c}(2) \\
\text { High RID }\end{array}$ & $\begin{array}{c}(3) \\
\text { Low RID }\end{array}$ & $\begin{array}{l}(4) \\
\text { All }\end{array}$ & $\begin{array}{c}(5) \\
\text { High RID }\end{array}$ & $\begin{array}{c}(6) \\
\text { Low RID }\end{array}$ \\
\hline \multirow[t]{2}{*}{$\overline{\mathrm{BTT}}$} & $0.232^{* * *}$ & $0.461^{* * *}$ & -0.022 & $0.132 *$ & $0.338^{* * *}$ & -0.089 \\
\hline & $(0.066)$ & $(0.077)$ & $(0.086)$ & $(0.072)$ & $(0.083)$ & $(0.088)$ \\
\hline $\ln \left(G D P_{u s}+G D P_{d}\right)$ & & & & $\begin{array}{l}7.062^{* *} \\
(3.129)\end{array}$ & $\begin{array}{l}6.658^{*} \\
(3.451)\end{array}$ & $\begin{array}{c}7.331 * * * \\
(2.800)\end{array}$ \\
\hline \multirow[t]{2}{*}{$\ln \left(G D P_{u s}-G D P_{d}\right)^{2}$} & & & & $0.480^{*}$ & $0.512^{*}$ & $0.416^{*}$ \\
\hline & & & & $(0.264)$ & $(0.286)$ & $(0.244)$ \\
\hline \multirow[t]{2}{*}{$\ln$ (Skill Difference) } & & & & $-0.185^{*}$ & $-0.173^{*}$ & $-0.195^{* *}$ \\
\hline & & & & $(0.095)$ & $(0.102)$ & $(0.087)$ \\
\hline \multirow[t]{2}{*}{$\ln$ (Trade Costs) } & & & & 0.031 & 0.029 & 0.033 \\
\hline & & & & $(0.034)$ & $(0.036)$ & $(0.032)$ \\
\hline \multirow[t]{2}{*}{ BIT } & & & & $-0.548^{* *}$ & $-0.528^{*}$ & $-0.566^{* *}$ \\
\hline & & & & $(0.258)$ & $(0.279)$ & $(0.240)$ \\
\hline \multirow[t]{2}{*}{ FTA } & & & & 0.016 & 0.075 & -0.05 \\
\hline & & & & $(0.105)$ & $(0.099)$ & $(0.112)$ \\
\hline \multirow[t]{2}{*}{ Exchange Rate } & & & & -0.00002 & -0.00003 & -0.00001 \\
\hline & & & & $(0.000)$ & $(0.000)$ & $(0.000)$ \\
\hline \multirow[t]{2}{*}{ Parent-Sibling BTTs } & & & & $-0.044^{*}$ & $-0.046^{* *}$ & -0.044 \\
\hline & & & & $(0.026)$ & $(0.021)$ & $(0.033)$ \\
\hline \multirow[t]{2}{*}{ Affiliate-Sibling BTTs } & & & & $0.133^{*}$ & $0.173^{* *}$ & 0.083 \\
\hline & & & & $(0.075)$ & $(0.081)$ & $(0.090)$ \\
\hline Affiliate FE & YES & YES & YES & YES & YES & YES \\
\hline Industry-Year FE & YES & YES & YES & YES & YES & YES \\
\hline $\mathrm{N}$ & 342239 & 197116 & 145123 & 342239 & 197116 & 145123 \\
\hline R-sq & 0.0014 & 0.0047 & 0.0001 & 0.0131 & 0.015 & 0.0145 \\
\hline F-Statistic & 12.47 & 35.58 & 0.06 & 7.31 & 24.31 & 4.12 \\
\hline
\end{tabular}

Notes: Documents the effect of newly-signed Bilateral Tax Treaties (BTTs) on foreign affiliate employment. "High RID" and "Low RID" refer to firms within industries that exhibit ratios of total payments in royalties, interest, and dividends relative to total industry sales that are above and below the median sector (see Appendix A.2 for details). Sample covers 1987-2007. Standard errors clustered by both affiliate country and year are in parentheses. ${ }^{*},{ }^{* *}$, and $* * *$ indicate significance at the 10 , 5 , and 1 percent levels, respectively. 
Table 5: U.S. Parent-Level Analysis:

The Effect of Offshore Employment on Domestic MNE Employment

Dependent variable: $\log$ parent employment: $\ln \left(s_{f t}\right)$

\begin{tabular}{|c|c|c|c|c|c|c|}
\hline & (1) & $(2)$ & (3) & (4) & $(5)$ & (6) \\
\hline Specification: & OLS & OLS & IV & IV & IV & IV \\
\hline Sample: & All & All & All & All & New Aff & Cont Aff \\
\hline $\begin{array}{l}\text { log affiliate employment: } \\
\left(\ln M_{i t}\right)\end{array}$ & $\begin{array}{c}0.289^{* * *} \\
(0.017)\end{array}$ & $\begin{array}{c}0.263^{* * *} \\
(0.017)\end{array}$ & $\begin{array}{c}0.174^{* * *} \\
(0.017)\end{array}$ & $\begin{array}{c}0.130^{* * *} \\
(0.015)\end{array}$ & $\begin{array}{c}0.103 \\
(0.116)\end{array}$ & $\begin{array}{c}0.139^{* * *} \\
(0.016)\end{array}$ \\
\hline $\ln \left(G D P_{u s}+G D P_{d}\right)$ & & $\begin{array}{l}-0.039 \\
(0.126)\end{array}$ & & $\begin{array}{c}0.006 \\
(0.092)\end{array}$ & $\begin{array}{l}-0.331 \\
(0.366)\end{array}$ & $\begin{array}{l}-0.004 \\
(0.088)\end{array}$ \\
\hline $\ln \left(G D P_{u s}-G D P_{d}\right)^{2}$ & & $\begin{array}{l}-0.006 \\
(0.064)\end{array}$ & & $\begin{array}{l}-0.007 \\
(0.047)\end{array}$ & $\begin{array}{c}0.148 \\
(0.189)\end{array}$ & $\begin{array}{l}-0.001 \\
(0.045)\end{array}$ \\
\hline $\ln$ (Skill Difference) & & $\begin{array}{c}-0.167^{* * *} * \\
(0.057)\end{array}$ & & $\begin{array}{c}-0.097^{* * *} \\
(0.044)\end{array}$ & $\begin{array}{c}0.093 \\
(0.106)\end{array}$ & $\begin{array}{c}-0.118^{* *} \\
(0.047)\end{array}$ \\
\hline $\ln$ (Trade Costs) & & $\begin{array}{c}0.005 \\
(0.018)\end{array}$ & & $\begin{array}{l}-0.017 \\
(0.013)\end{array}$ & $\begin{array}{c}0.017 \\
(0.035)\end{array}$ & $\begin{array}{l}-0.02 \\
(0.014)\end{array}$ \\
\hline BIT & & $\begin{array}{c}-0.473^{*} \\
(0.25)\end{array}$ & & $\begin{array}{c}-0.432^{* *} \\
(0.167)\end{array}$ & $\begin{array}{l}-0.335 \\
(0.208)\end{array}$ & $\begin{array}{c}-0.460^{* *} \\
(0.201)\end{array}$ \\
\hline FTA & & $\begin{array}{l}-0.016 \\
(0.082)\end{array}$ & & $\begin{array}{l}-0.004 \\
(0.048)\end{array}$ & $\begin{array}{c}0.083 \\
(0.125)\end{array}$ & $\begin{array}{l}-0.009 \\
(0.053)\end{array}$ \\
\hline Exchange Rate & & $\begin{array}{l}-0.000 \\
(0.000)\end{array}$ & & $\begin{array}{l}-0.000 \\
(0.000)\end{array}$ & $\begin{array}{c}0.000 \\
(0.000)\end{array}$ & $\begin{array}{l}-0.000 \\
(0.000)\end{array}$ \\
\hline Parent FE & YES & YES & YES & YES & YES & YES \\
\hline Year FE & YES & YES & YES & YES & YES & YES \\
\hline $\mathrm{N}$ & 29765 & 29765 & 29765 & 29765 & 6077 & 23688 \\
\hline R-sq & 0.1865 & 0.2189 & 0.1406 & 0.1581 & 0.3536 & 0.1663 \\
\hline First Stage F-Stat & - & - & 508.14 & 413.36 & 117.5 & 402.53 \\
\hline Endog Test P-Val & - & - & 0.0017 & 0.0019 & 0.0022 & 0.0015 \\
\hline
\end{tabular}

Notes: Documents the effects of BTT-induced changes in foreign-affiliate employment on domestic employment of multinational firms in industries that exhibit high ratios of royalty, interest, and dividend payments relative to total industry sales. Columns (5) and (6) respectively restrict the sample to parent firms that did and did not open new affiliates in countries newly receiving a BTT. First-stage F-statistics are large for all IV specifications, though the relevant F-statistics for weak-instrument concerns appear in columns (2) and (5) of Table 4 (see text for discussion). In all IV specifications, the equality of OLS and IV is rejected. Sample covers 1987-2007. Standard errors clustered by parent firm and year are in parentheses. *,*, and *** indicate significance at the 10,5, and 1 percent levels, respectively. 
Table 6: U.S. Industry-Level Analysis:

The Effect of Offshore Employment on U.S. Industry Employment

Dependent variable: $\log$ industry employment: $\ln \left(L_{i t}\right)$

\begin{tabular}{|c|c|c|c|c|}
\hline & (1) & $(2)$ & (3) & (4) \\
\hline Specification: & OLS & OLS & IV & IV \\
\hline $\begin{array}{l}\log \text { affiliate employment: } \\
\qquad\left(\ln M_{i t}\right)\end{array}$ & $\begin{array}{c}0.013^{* * *} \\
(0.005)\end{array}$ & $\begin{array}{l}0.011^{* *} \\
(0.005)\end{array}$ & $\begin{array}{c}0.006^{* *} \\
(0.003)\end{array}$ & $\begin{array}{l}0.006^{* *} \\
(0.003)\end{array}$ \\
\hline $\ln \left(G D P_{u s}+G D P_{d}\right)$ & & $\begin{array}{c}-0.062 \\
(0.094)\end{array}$ & & $\begin{array}{r}-0.017 \\
(0.06)\end{array}$ \\
\hline $\ln \left(G D P_{u s}-G D P_{d}\right)^{2}$ & & $\begin{array}{c}0.023 \\
(0.048)\end{array}$ & & $\begin{array}{c}0.006 \\
(0.018)\end{array}$ \\
\hline $\ln$ (Skill Difference) & & $\begin{array}{c}0.029 \\
(0.046)\end{array}$ & & $\begin{array}{c}0.01 \\
(0.017)\end{array}$ \\
\hline $\ln$ (Trade Costs) & & $\begin{array}{r}0.031^{* *} \\
(0.014)\end{array}$ & & $\begin{array}{l}0.011^{* *} \\
(0.005)\end{array}$ \\
\hline BIT & & $\begin{array}{l}-0.019 \\
(0.056)\end{array}$ & & $\begin{array}{l}-0.006 \\
(0.021)\end{array}$ \\
\hline FTA & & $\begin{array}{c}0.036 \\
(0.043)\end{array}$ & & $\begin{array}{c}0.013 \\
(0.016)\end{array}$ \\
\hline Exchange Rate & & $\begin{array}{l}-0.000 \\
(0.000)\end{array}$ & & $\begin{array}{l}-0.000 \\
(0.000)\end{array}$ \\
\hline Industry FE & YES & YES & YES & YES \\
\hline Year FE & YES & YES & YES & YES \\
\hline $\mathrm{N}$ & 1268 & 1268 & 1268 & 1268 \\
\hline R-sq & 0.4836 & 0.5309 & 0.4821 & 0.5292 \\
\hline First Stage F-Stat & - & - & 234.99 & 208.2 \\
\hline Endog Test P-Val & - & - & 0.0213 & 0.0225 \\
\hline
\end{tabular}

Notes: Documents the effects of BTT-induced changes in foreign-affiliate employment at the industry level for industries that exhibit high ratios of royalty, interest, and dividend payments relative to total industry sales. First-stage F-statistics are large for all IV specifications, though the relevant F-statistics for weak-instrument concerns appear in columns (2) and (5) of Table 4 (see text for discussion). In all IV specifications, the equality of OLS and IV is rejected. Sample covers 1987-2007. Standard errors clustered by industry and year are in parentheses. $* * *$, and $* * *$ indicate significance at the 10,5 , and 1 percent levels, respectively. 
Table 7: U.S. Industry Level Analysis:

The Effect of Offshore Employment on U.S. MNE vs. non-MNE Employment

Dependent variable: $\log$ industry employment: $\ln \left(L_{i t}\right)$

\begin{tabular}{|c|c|c|c|c|}
\hline & (1) & (2) & (3) & (4) \\
\hline Specification: & IV & IV & IV & IV \\
\hline Sample: & MNE & MNE & non-MNE & non-MNE \\
\hline $\begin{array}{l}\text { industry log affiliate employment: } \\
\qquad\left(\ln M_{i t}\right)\end{array}$ & $\begin{array}{c}0.042^{* * *} \\
(0.005)\end{array}$ & $\begin{array}{c}0.043^{* * *} \\
(0.005)\end{array}$ & $\begin{array}{l}0.0009 \\
(0.004)\end{array}$ & $\begin{array}{l}-0.001 \\
(0.005)\end{array}$ \\
\hline $\ln \left(G D P_{u s}+G D P_{d}\right)$ & & $\begin{array}{c}0.097 \\
(0.093)\end{array}$ & & $\begin{array}{c}-0.036 \\
(0.046)\end{array}$ \\
\hline $\ln \left(G D P_{u s}-G D P_{d}\right)^{2}$ & & $\begin{array}{l}-0.048 \\
(0.048)\end{array}$ & & $\begin{array}{c}0.015 \\
(0.024)\end{array}$ \\
\hline $\ln ($ Skill Difference) & & $\begin{array}{c}-0.06 \\
(0.037)\end{array}$ & & $\begin{array}{c}0.015 \\
(0.022)\end{array}$ \\
\hline $\ln$ (Trade Costs) & & $\begin{array}{c}-0.006 \\
(0.007)\end{array}$ & & $\begin{array}{c}0.011 \\
(0.009)\end{array}$ \\
\hline BIT & & $\begin{array}{c}0.047 \\
(0.066)\end{array}$ & & $\begin{array}{l}-0.009 \\
(0.026)\end{array}$ \\
\hline FTA & & $\begin{array}{c}0.06 \\
(0.036)\end{array}$ & & $\begin{array}{c}0.015 \\
(0.016)\end{array}$ \\
\hline Exchange Rate & & $\begin{array}{c}-0.00002 \\
(0.000)\end{array}$ & & $\begin{array}{c}-0.00001 \\
(0.000)\end{array}$ \\
\hline Industry FE & YES & YES & YES & YES \\
\hline Year FE & YES & YES & YES & YES \\
\hline $\mathrm{N}$ & 1268 & 1268 & 1268 & 1268 \\
\hline R-sq & 0.2678 & 0.3086 & 0.4244 & 0.4702 \\
\hline First Stage F-Stat & 276.32 & 205.84 & 214.75 & 189.12 \\
\hline Endog Test P-Val & 0.0089 & 0.0052 & 0.0198 & 0.0187 \\
\hline
\end{tabular}

Notes: Documents the effects of BTT-induced changes in foreign-affiliate employment at the industry level for industries that exhibit high ratios of royalty, interest, and dividend payments relative to total industry sales. Columns (1) and (2) examine employment for multinational parents in the U.S. industry while columns (3) and (4) examine all other employment in each industry. First-stage F-statistics are large for all IV specifications, though the relevant F-statistics for weak-instrument concerns appear in columns (2) and (5) of Table 4 (see text for discussion). In all IV specifications, the equality of OLS and IV is rejected. Sample covers 1987-2007. Standard errors clustered by industry and year are in parentheses. ***, and *** indicate significance at the 10,5 , and 1 percent levels, respectively. 
Table 8: U.S. Industry Level Analysis:

The Effect of Offshore Employment at Vertically Oriented Affiliates on U.S. MNE vs. non-MNE Employment

Dependent variable: $\log$ industry employment: $\ln \left(L_{i t}\right)$

\begin{tabular}{|c|c|c|c|c|}
\hline & (1) & $(2)$ & (3) & (4) \\
\hline Specification: & IV & IV & IV & IV \\
\hline Sample: & V-MNE & V-MNE & non-MNE & non-MNE \\
\hline $\begin{array}{r}\text { industry log affiliate employment: } \\
\qquad\left(\ln M_{i t}\right)\end{array}$ & $\begin{array}{c}0.144^{* * *} \\
(0.022)\end{array}$ & $\begin{array}{c}0.143^{* * *} \\
(0.022)\end{array}$ & $\begin{array}{c}-0.016^{* *} \\
(0.007)\end{array}$ & $\begin{array}{c}-0.023^{* * *} \\
(0.008)\end{array}$ \\
\hline $\ln \left(G D P_{u s}+G D P_{d}\right)$ & & $\begin{array}{l}-0.373 \\
(0.676)\end{array}$ & & $\begin{array}{l}-0.297 \\
(0.299)\end{array}$ \\
\hline $\ln \left(G D P_{u s}-G D P_{d}\right)^{2}$ & & $\begin{array}{c}0.207 \\
(0.341)\end{array}$ & & $\begin{array}{l}0.143 \\
(0.15)\end{array}$ \\
\hline $\ln$ (Skill Difference) & & $\begin{array}{c}-0.416^{* * *} \\
(0.135)\end{array}$ & & $\begin{array}{c}0.059 \\
(0.117)\end{array}$ \\
\hline $\ln$ (Trade Costs) & & $\begin{array}{l}-0.006 \\
(0.034)\end{array}$ & & $\begin{array}{l}-0.001 \\
(0.017)\end{array}$ \\
\hline BIT & & $\begin{array}{l}-0.036 \\
(0.257)\end{array}$ & & $\begin{array}{l}0.447^{* * *} \\
\quad(0.17)\end{array}$ \\
\hline FTA & & $\begin{array}{l}-0.013 \\
(0.151)\end{array}$ & & $\begin{array}{c}0.14 \\
(0.090)\end{array}$ \\
\hline Exchange Rate & & $\begin{array}{c}0.000 \\
(0.000)\end{array}$ & & $\begin{array}{c}0.000 \\
(0.000)\end{array}$ \\
\hline Industry FE & YES & YES & YES & YES \\
\hline Year FE & YES & YES & YES & YES \\
\hline $\mathrm{N}$ & 1217 & 1217 & 1217 & 1217 \\
\hline $\mathrm{R}$-sq & 0.1535 & 0.1769 & 0.4529 & 0.5009 \\
\hline First Stage F-Stat & 249.75 & 214.42 & 274.63 & 223.05 \\
\hline Endog Test P-Val & 0.0093 & 0.0069 & 0.0194 & 0.0178 \\
\hline
\end{tabular}

Notes: Documents the effects of BTT-induced changes in foreign-affiliate employment at foreign affiliates that have non-zero sales to their U.S. parent on domestic employment at the industry level for industries that exhibit high ratios of royalty, interest, and dividend payments relative to total industry sales. Columns (1) and (2) examine employment for multinational parents in the U.S. industry while columns (3) and (4) examine all other employment in each industry. First-stage F-statistics are large for all IV specifications, though the relevant F-statistics for weak-instrument concerns appear in columns (2) and (5) of Table 4 (see text for discussion). In all IV specifications, the equality of OLS and IV is rejected. Sample covers 1987-2007. Standard errors clustered by industry and year are in parentheses. $* * *$, and $* * *$ indicate significance at the 10,5 , and 1 percent levels, respectively. 
Table 9: U.S. Metro Area Level Analysis:

The Effect of Offshore Employment on U.S. Regional Employment

Dependent variable: $\log$ regional employment: $\ln \left(L_{m t}\right)$

\begin{tabular}{|c|c|c|c|c|}
\hline Specification: & $\begin{array}{l}(1) \\
\text { OLS }\end{array}$ & $\begin{array}{l}(2) \\
\text { OLS }\end{array}$ & $\begin{array}{l}(3) \\
\text { IV }\end{array}$ & $\begin{array}{l}(4) \\
\text { IV }\end{array}$ \\
\hline $\begin{array}{r}\text { regional log affiliate employment: } \\
\qquad\left(\ln M_{m t}\right)\end{array}$ & $\begin{array}{c}0.035^{* * *} \\
(0.008)\end{array}$ & $\begin{array}{c}0.033^{* * *} \\
(0.008)\end{array}$ & $\begin{array}{c}0.018^{* * *} \\
(0.004)\end{array}$ & $\begin{array}{c}0.017^{* * *} \\
(0.004)\end{array}$ \\
\hline $\ln \left(G D P_{u s}+G D P_{d}\right)$ & & $\begin{array}{c}-0.756^{* *} \\
(0.343)\end{array}$ & & $\begin{array}{c}-0.326^{* *} \\
(0.152)\end{array}$ \\
\hline $\ln \left(G D P_{u s}-G D P_{d}\right)^{2}$ & & $\begin{array}{c}0.365^{* *} \\
(0.173)\end{array}$ & & $\begin{array}{c}0.158 * * \\
(0.077)\end{array}$ \\
\hline ln(Skill Difference) & & $\begin{array}{c}0.209 \\
(0.129)\end{array}$ & & $\begin{array}{c}0.094 \\
(0.057)\end{array}$ \\
\hline $\ln$ (Trade Costs) & & $\begin{array}{c}0.058 \\
(0.060)\end{array}$ & & $\begin{array}{c}0.022 \\
(0.026)\end{array}$ \\
\hline BIT & & $\begin{array}{c}0.077 \\
(0.289)\end{array}$ & & $\begin{array}{c}0.030 \\
(0.127)\end{array}$ \\
\hline FTA & & $\begin{array}{c}0.010 \\
(0.091)\end{array}$ & & $\begin{array}{c}0.003 \\
(0.040)\end{array}$ \\
\hline Exchange Rate & & $\begin{array}{l}-0.0009 \\
(0.001)\end{array}$ & & $\begin{array}{c}-0.0004 \\
(0.000) \\
\end{array}$ \\
\hline Industry FE & YES & YES & YES & YES \\
\hline Year FE & YES & YES & YES & YES \\
\hline $\mathrm{N}$ & 6080 & 6080 & 6080 & 6080 \\
\hline R-sq & 0.7312 & 0.7377 & 0.7308 & 0.7374 \\
\hline First Stage F-Stat & - & - & 165.96 & 171.84 \\
\hline Endog Test P-Val & - & - & 0.0205 & 0.0249 \\
\hline
\end{tabular}

Notes: Documents the effects of BTT-induced changes in foreign-affiliate employment on domestic employment at the region level. First-stage F-statistics are large for all IV specifications, though the relevant F-statistics for weak-instrument concerns appear in columns (2) and (5) of Table 4 (see text for discussion). In all IV specifications, the equality of OLS and IV is rejected. Sample covers 1987-2007. Standard errors clustered by parent firm and year are in parentheses. ${ }^{*}, * *$, and $* * *$ indicate significance at the 10,5 , and 1 percent levels, respectively. 


\section{Online Appendices}

(Not for publication)

\begin{tabular}{|l|}
\hline A Data, Definitions, and Supplemental Empirical Results \\
\hline
\end{tabular}

A.1 Yearly Coverage Relative to BTT Dates . . . . . . . . . . . . . . 2

A.2 High versus Low RID Industries . . . . . . . . . . . . . . . . . 3

A.3 Alternative Specifications for BTTs' Effects on Employment at U.S. Multina-

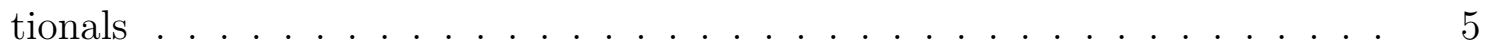

A.4 Empirical Results Using Variation in the Change in Withholding Tax Rates. 9

A.5 $\quad$ Empirical Results for Vertically Oriented Multinational Firms . . . . . . . . 17

A.6 Imputation in CBP Employment Data . . . . . . . . . . . . . . . . 25

B Supplemental Theoretical and Econometric Results 27

B.1 Detailed Model of Double Taxation . . . . . . . . . . . . . . . . . . . 27

B.2 Model with CES Production . . . . . . . . . . . . . . . . . . . . . 30

B.3 Smearing . . . . . . . . . . . . . . . . . . . . . 32 


\section{A Data, Definitions, and Supplemental Empirical Re- sults}

\section{A.1 Yearly Coverage Relative to BTT Dates}

Figure A1 shows the coverage our 1987-2007 sample provides relative to the date in which each country's BTT went into force, making clear that we can observe many pre-BTT years for some countries and many post-BTT years for others.

Figure A1: Sample Coverage Relative to BTT Implementation

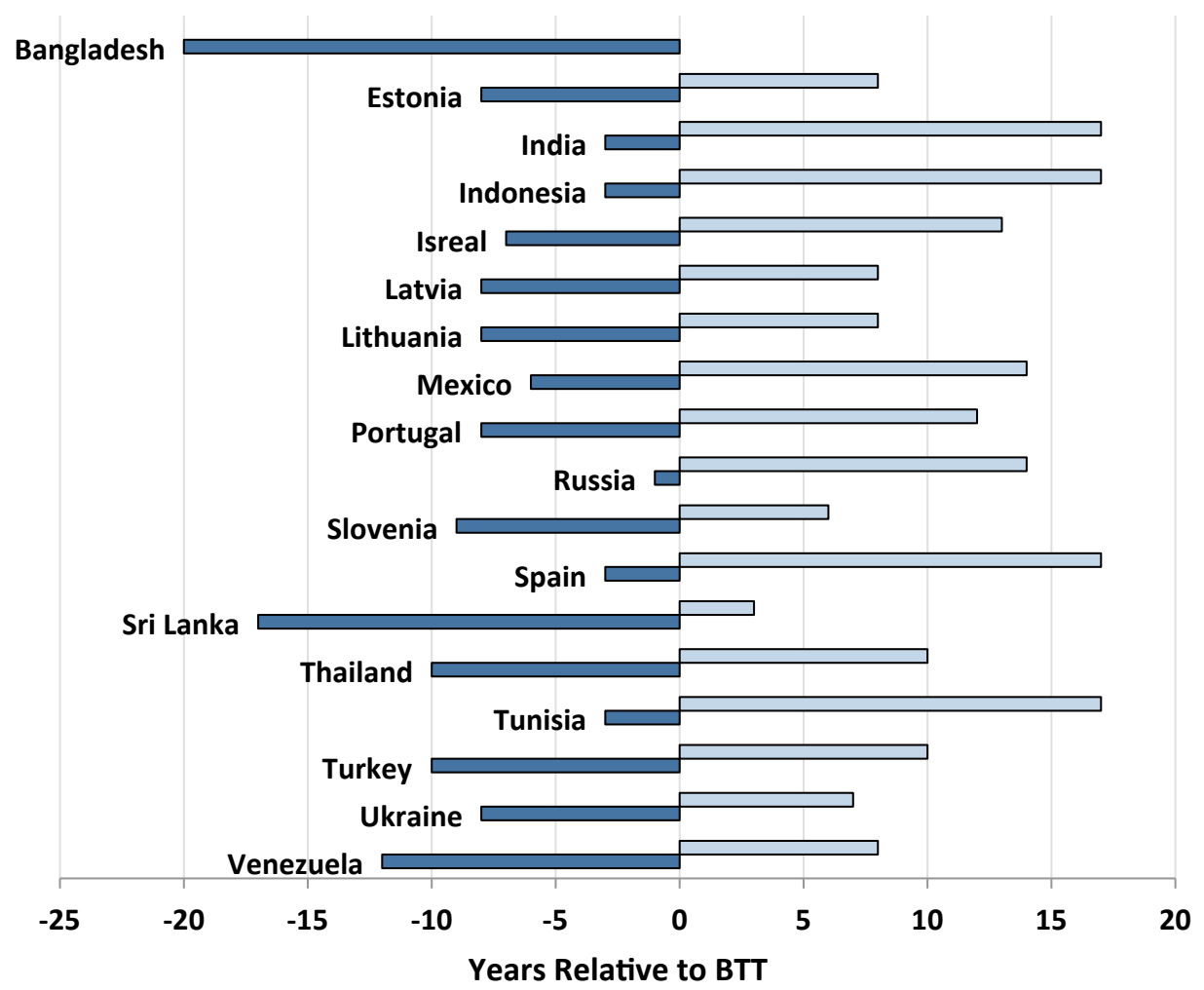

Source: Authors' calculations based on BEA Annual Surveys of U.S. Direct Investment Abroad 1987-2007 and information from U.S. Treasury publications (see footnote 11). BTT implementation dates appear in Table 1 Each country shown has a new BTT during our sample period. Darker bars show the number of available years before the BTT and lighter bars show the number of available years after the BTT. Note that Estonia, Latvia, and Lithuania first appear in the BEA data in 1991, while Russia, Slovenia, and Ukraine first appear in 1992. 


\section{A.2 High versus Low RID Industries}

As discussed in Section 2, double taxation is more likely to occur in industries where the value of withholding taxes paid to foreign tax authorities is large. Limits on the foreign tax credit available to U.S. multinational firms are more likely to bind when the amount of income subject to taxation by a foreign authority - in the form of royalties, interest, and dividends - is high. Appendix B.1 formally demonstrates this argument in a general context of payments from a foreign affiliate to a U.S. parent firm. The purpose of this section is to provide details on how we delineate industries with high versus low royalty, interest, and dividend payments (RID), and thus high and low exposure to treatment from a BTT.

The BEA collects information on the total value of royalty, interest, and dividend payments from each foreign affiliate to its U.S. multinational parent firm in their Benchmark Surveys of U.S. Foreign Direct Investment Abroad. These surveys are conducted every five years and contain information such as details about royalty, interest, and dividend payments, that are not available in the annual surveys. We use information on the value of RID payments from the 1989 benchmark survey, which is the earliest available benchmark year, to minimize concerns about endogeneity. We aggregate total RID payments by 3-digit industry and country, and then calculate the ratio of total RID payments to total foreign affiliate sales for each industry-by-country cell. We then regress this ratio on an industry fixed effect and a country fixed effect. The value of the industry fixed effect is our measure of RID intensity for a particular industry, independent of country-specific factors that may otherwise affect RID payments. We classify those industries with RID intensity above the observed median as being high RID industries and those below the median as being low RID industries, as shown in Table A1 
Table A1: Industry Classification by Royalties, Interest, and Dividend Payments as a Share of Total Foreign Affiliate Sales

\begin{tabular}{|c|c|c|c|c|c|}
\hline \multicolumn{3}{|r|}{ "Low RID } & \multicolumn{3}{|r|}{ "High RID } \\
\hline Rank & SIC & SIC Name & Rank & SIC & SIC Name \\
\hline 1 & 505 & Metals and minerals, except petroleum Wholesale & 61 & 477 & Transportation, nec, and related services \\
\hline 2 & 250 & Furniture and fixtures Mfg & 62 & 742 & Information retrieval services \\
\hline 3 & 530 & General merchandise retail stores & 63 & 554 & Gasoline service stations \\
\hline 4 & 120 & Coal mining & 64 & 352 & Farm and garden machinery Mfg \\
\hline 5 & 631 & Life insurance & 65 & 483 & Other communications services \\
\hline 6 & 810 & Legal services & 66 & 461 & Pipelines, petroleum and natural gas \\
\hline 7 & 540 & Food retail stores & 67 & 873 & Research, development, and testing services \\
\hline 8 & 449 & Water transportation & 68 & 752 & Automotive parking, repair, and other services \\
\hline 9 & 470 & Petroleum storage for hire & 69 & 262 & Pulp, paper, and board mills Mfg \\
\hline 10 & 507 & Hardware, \& plumbing \& heating equipment Wholesale & 70 & 501 & Motor vehicles and equipment Wholesale \\
\hline 11 & 515 & Farm product raw materials Wholesale & 71 & 590 & Retail, nec \\
\hline 12 & 503 & Lumber and other construction materials Wholesale & 72 & 560 & Apparel and accessory retail stores \\
\hline 13 & 871 & Engineering, architectural, and surveying services & 73 & 230 & Apparel and other textile products Mfg \\
\hline 14 & 379 & Other transportation equipment, nec Mfg & 74 & 201 & Meat products Mfg \\
\hline 15 & 639 & Other insurance & 75 & 204 & Grain mill products Mfg \\
\hline 16 & 632 & Accident and health insurance & 76 & 354 & Metalworking machinery Mfg \\
\hline 17 & 800 & Health services & 77 & 331 & Ferrous Metals Mfg \\
\hline 18 & 363 & Household appliances Mfg & 78 & 205 & Bakery products Mfg \\
\hline 19 & 138 & Oil and gas field services & 79 & 481 & Telephone and telegraph communications \\
\hline 20 & 292 & Petroleum refining without extraction & 80 & 351 & Engines and turbines Mfg \\
\hline 21 & 600 & Depository Institutions & 81 & 353 & Construction, mining, \& materials handling Mfg \\
\hline 22 & 140 & Nonmetallic minerals mining, except fuels & 82 & 355 & Special industry machinery Mfg \\
\hline 23 & 511 & Paper and paper products Wholesale & 83 & 780 & Motion pictures, including television tape and film \\
\hline 24 & 514 & Groceries and related products Wholesale & 84 & 208 & Beverages Mfg \\
\hline 25 & 731 & Advertising & 85 & 508 & Machinery, equipment, and supplies Wholesale \\
\hline 26 & 20 & Agricultural production-livestock and animal & 86 & 450 & Transportation by air \\
\hline 27 & 341 & Metal cans, forgings, and stampings Mfg & 87 & 743 & Computer related services, nec \\
\hline 28 & 349 & Metal services, ordinance, \& fabricated metal Mfg & 88 & 272 & Miscellaneous publishing Mfg \\
\hline 29 & 751 & Automotive rental and leasing, without drivers & 89 & 749 & Business sevices, nec \\
\hline 30 & 202 & Dairy products Mfg & 90 & 369 & Electronic and other electric equipment, nec Mfg \\
\hline 31 & 359 & Industrial machinery and equipment, nec Mfg & 91 & 512 & Drugs, proprietaries, \& sundries Wholesale \\
\hline 32 & 358 & Refrigeration and service industry machinery Mfg & 92 & 102 & Copper, lead, zinc, gold, and silver ores mining \\
\hline 33 & 203 & Preserved fruits and vegetables Mfg & 93 & 390 & Miscellaneous manufacturing industries \\
\hline 34 & 240 & Lumber and wood products Mfg & 94 & 736 & Personnel supply services \\
\hline 35 & 335 & Nonferrous Metals Mfg & 95 & 872 & Accounting, auditing, and bookkeeping services \\
\hline 36 & 265 & Other paper and allied products Mfg & 96 & 890 & Other services provided on a commercial basis \\
\hline 37 & 519 & Nondurable goods, nec Wholesale & 97 & 329 & Stone, clay, concrete, gypsum, etc Mfg \\
\hline 38 & 107 & Other metallic ores mining & 98 & 612 & Other finance, including security and commodity br \\
\hline 39 & 760 & Miscellaneous repair services & 99 & 650 & Real estate \\
\hline 40 & 90 & Fishing, hunting, and trapping & 100 & 284 & Soap, cleaners, and toilet goods Mfg \\
\hline 41 & 275 & Commercial printing and services Mfg & 101 & 367 & Electronic components and accessories Mfg \\
\hline 42 & 308 & Miscellaneous plastics products Mfg & 102 & 509 & Durable goods, nec Wholesale \\
\hline 43 & 513 & Apparel, piece goods, \& notions Wholesale & 103 & 291 & Integrated petroleum refining and extraction \\
\hline 44 & 386 & Photographic equipment and supplies Mfg & 104 & 343 & Heating equipment, plumbing fixtures, etc Mfg \\
\hline 45 & 305 & Rubber products Mfg & 105 & 366 & Household audio \& video, \& communications Mfg \\
\hline 46 & 289 & Chemical products, nec Mfg & 106 & 741 & Computer processing and data preparation services \\
\hline 47 & 210 & Tobacco products Mfg & 107 & 735 & Equipment rental and leasing, exc automobiles \\
\hline 48 & 299 & Petroleum and coal products, nec & 108 & 504 & Professional \& commerical eq \& supplies Wholesale \\
\hline 49 & 310 & Leather and leather products Mfg & 109 & 10 & Agricultural production-crops \\
\hline 50 & 506 & Electrical goods Wholesale & 110 & 283 & Drugs Mfg \\
\hline 51 & 321 & Glass products Mfg & 111 & 220 & Textile mill products Mfg \\
\hline 52 & 108 & Metal mining services & 112 & 342 & Cutlery, hardware, and screw products Mfg \\
\hline 53 & 381 & Measuring, scientific, \& optical instruments Mfg & 113 & 357 & Computer and office equipment Mfg \\
\hline 54 & 281 & Industrial chemicals and synthetics Mfg & 114 & 133 & Crude petroleum (no refining) and natural gas \\
\hline 55 & 384 & Medical instruments \& supplies and ophthalmic Mfg & 115 & 287 & Agricultural chemicals Mfg \\
\hline 56 & 150 & Construction & 116 & 874 & Management and public relations services \\
\hline 57 & 700 & Hotels and other lodging places & 117 & 820 & Educational services \\
\hline 58 & 356 & General industrial machinery Mfg & 118 & 580 & Eating and drinking places \\
\hline 59 & 209 & Other food and kindred products Mfg & 119 & 790 & Amusement and recreation services \\
\hline 60 & 371 & Motor vehicles and equipment Mfg & 120 & 671 & Holding companies \\
\hline & & & 121 & 679 & Franchising, business - selling or licensing \\
\hline
\end{tabular}

Classification of industries into high-RID and low-RID groups. Ranks listed from low to high RID. See text for details. 


\section{A.3 Alternative Specifications for BTTs' Effects on Employment at U.S. Multinationals}

This section presents reduced-form specifications examining the effects of BTTs on domestic employment at U.S. multinational firms. The main results use the specifications in equations (1) and (2), with results in Table 3 and Figure 1.

We also estimate alternative difference-in-difference specifications that employ different weighting schemes to assign the value of treatment from a BTT. Our first alternative specification drops the affiliate employment rescaling term, $\tilde{\varphi}_{f}$ from the BTT indicator, so the variable of interest is simply $\mathbf{1}\left(t \geq \tilde{t}_{f}\right)$. The difference-in-difference and event study results appear in Table A2 and Figure A2. As in the main specification, the effect of BTTs is positive, and significant only for high RID firms. The scale of the coefficients is smaller however, reflecting the fact that the scale of the regressor is larger without the affiliate employment share adjustment. As in the main specification, there is no sign of pre-BTT differential employment growth between firms with and without affiliates receiving a BTT, and the employment effects emerge in the period of BTT implementation ( $t=0$ in Figure A2).

Our second alternative integrates information from all BTTs faced by affiliates during our sample period, not just the first one as in the main analysis or the previous alternative. For a given multinational firm $f$, we examine the share of initial affiliate employment covered by BTTs in year $t$ (see footnote 16 for notation definitions).

$$
\overline{B T T}_{f t} \equiv \sum_{c \in C_{f}} \varphi_{f, c} \mathbf{1}\left(t \geq t_{c}\right), \quad \varphi_{f, c} \equiv \frac{m_{f, c, \tilde{t}_{f}-1}}{\sum_{c^{\prime} \in C_{f}} m_{f, c^{\prime}, \tilde{t}_{f}-1}}
$$

where $\varphi_{f, c}$ is affiliate $c$ 's initial share of firm $f$ 's total affiliate employment. We measure affiliate employment in the year prior to the first BTT faced by the firm $\left(\tilde{t}_{f}-1\right)$ to avoid including any endogenous employment adjustments. Because a given parent firm may be "treated" multiple times by receiving BTTs in multiple affiliate countries over time, we can not implement a traditional event study, as we did when focusing only on the first BTT a firm experiences. However, we can use a similar approach to rule out the presence of confounding pre-BTT trends by including leads and lags of the BTT coverage measure in (15). Figure A3 plots the associated coefficients, confirming the similarity of pre-existing employment growth rates for firms that would and would not later experience increases BTT coverage. 
Table A2: Reduced Form Difference-in-Differences Analysis Without Affiliate Scaling: The Effect of BTTs on Parent Employment

Dependent variable: $\log$ parent employment: $\ln \left(s_{f t}\right)$

\begin{tabular}{|c|c|c|c|c|c|c|}
\hline Sample: & $\begin{array}{l}(1) \\
\text { All }\end{array}$ & $\begin{array}{c}(2) \\
\text { High RID }\end{array}$ & $\begin{array}{c}(3) \\
\text { Low RID }\end{array}$ & $\begin{array}{l}(4) \\
\text { All }\end{array}$ & $\begin{array}{c}(5) \\
\text { High RID }\end{array}$ & $\begin{array}{c}(6) \\
\text { Low RID }\end{array}$ \\
\hline $\operatorname{BTT}\left[\mathbf{1}\left(t \geq \tilde{t}_{f}\right)\right]$ & $\begin{array}{c}0.013 \\
(0.015)\end{array}$ & $\begin{array}{c}0.022^{* * *} \\
(0.008)\end{array}$ & $\begin{array}{l}-0.008 \\
(0.025)\end{array}$ & $\begin{array}{l}0.015 \\
(0.05)\end{array}$ & $\begin{array}{c}0.039 * * * \\
(0.015)\end{array}$ & $\begin{array}{c}-0.008 \\
(0.025)\end{array}$ \\
\hline $\ln \left(G D P_{u s}+G D P_{d}\right)$ & & & & $\begin{array}{c}0.02 \\
(0.121)\end{array}$ & $\begin{array}{l}-0.063 \\
(0.145)\end{array}$ & $\begin{array}{c}0.163 \\
(0.193)\end{array}$ \\
\hline $\ln \left(G D P_{u s}-G D P_{d}\right)^{2}$ & & & & $\begin{array}{l}-0.052 \\
(0.059)\end{array}$ & $\begin{array}{l}-0.013 \\
(0.071)\end{array}$ & $\begin{array}{l}-0.118 \\
(0.096)\end{array}$ \\
\hline ln(Skill Difference) & & & & $\begin{array}{l}-0.074 \\
(0.047)\end{array}$ & $\begin{array}{l}-0.093 \\
(0.057)\end{array}$ & $\begin{array}{l}-0.048 \\
(0.095)\end{array}$ \\
\hline $\ln$ (Trade Costs) & & & & $\begin{array}{c}0.002 \\
(0.015)\end{array}$ & $\begin{array}{c}0.015 \\
(0.018)\end{array}$ & $\begin{array}{c}-0.002 \\
(0.030)\end{array}$ \\
\hline $\mathrm{BIT}$ & & & & $\begin{array}{c}-0.281 \\
(0.172)\end{array}$ & $\begin{array}{c}-0.259 \\
(0.237)\end{array}$ & $\begin{array}{l}-0.246 \\
(0.237)\end{array}$ \\
\hline FTA & & & & $\begin{array}{l}-0.008 \\
(0.062)\end{array}$ & $\begin{array}{l}-0.078 \\
(0.088)\end{array}$ & $\begin{array}{c}0.013 \\
(0.079)\end{array}$ \\
\hline Exchange Rate & & & & $\begin{array}{r}-0.0001 \\
(0.000)\end{array}$ & $\begin{array}{r}-0.0001 \\
(0.000)\end{array}$ & $\begin{array}{c}0.0001 \\
(0.000)\end{array}$ \\
\hline Parent FE & YES & YES & YES & YES & YES & YES \\
\hline Industry-Year FE & YES & YES & YES & YES & YES & YES \\
\hline $\mathrm{N}$ & 43233 & 29765 & 13468 & 43233 & 29765 & 13468 \\
\hline R-sq & 0.0014 & 0.0023 & 0.0004 & 0.0573 & 0.0643 & 0.0416 \\
\hline
\end{tabular}

Notes: Documents the effects of newly signed bilateral tax treaties (BTTs) on parent employment at multinational firms. "High RID" and "Low RID" refer to firms within industries that exhibit ratios of total payments in royalties, interest and dividends relative to total industry sales that are above and below the median sector (see Appendix A.2 for details). Sample covers 1987-2007. Standard errors clustered by both parent firm and year are in parentheses. $*, * *$, and $* * *$ indicate significance at the 10,5 , and 1 percent levels, respectively. 
Figure A2: Effect of BTTs on U.S. Multinational Firm Employment Without Affiliate Scaling

in High Royalty, Interest, and Dividend Industries

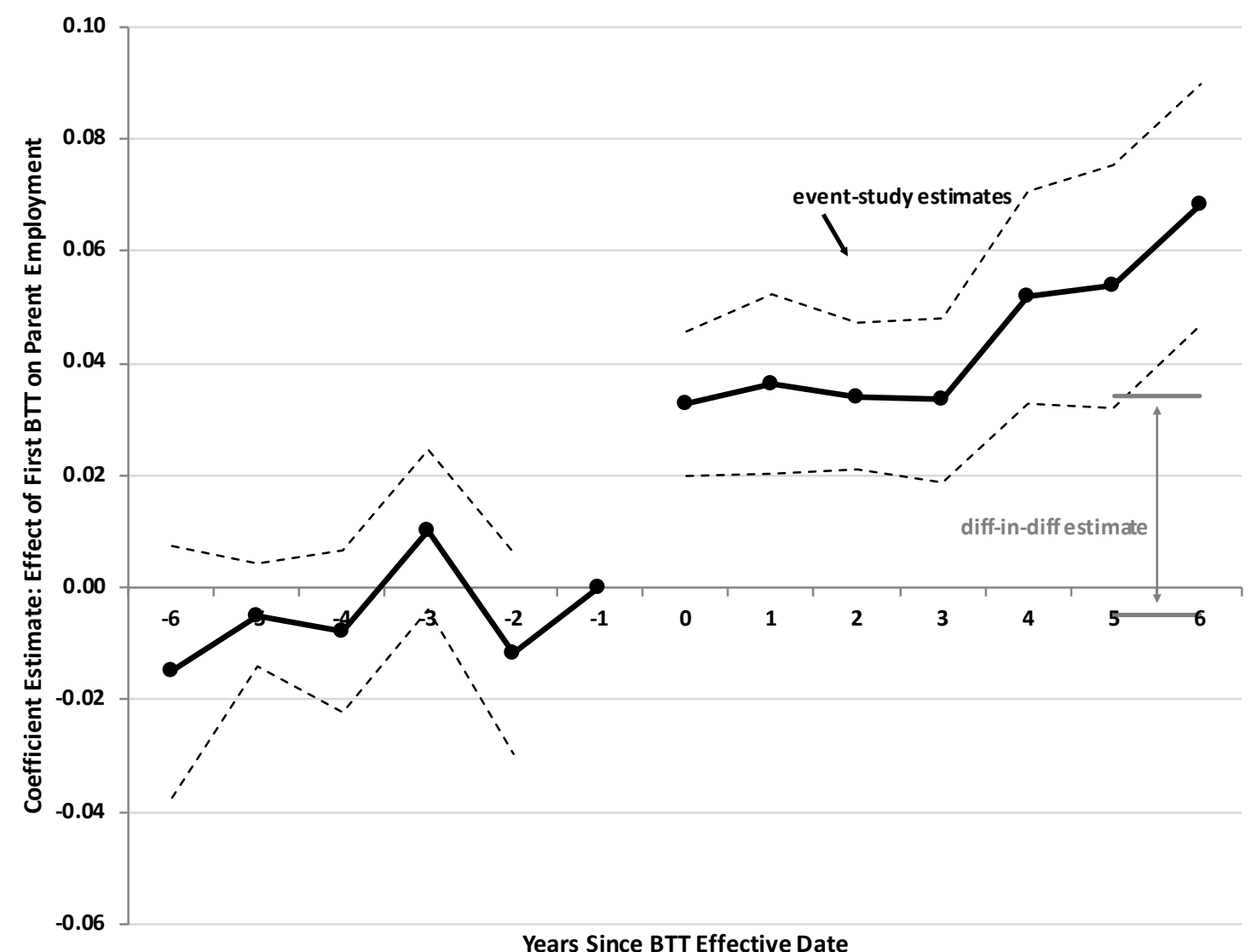

Source: Authors' calculations based on BEA Annual Surveys of U.S. Direct Investment Abroad 1987-2007. Sample restricted to firms in industries with high RID payments to U.S. parent firms. Each point on the black line represents a coefficient estimate from the event study specification in 22. Dashed lines reflect 95 percent confidence intervals for these event-study estimates when clustering standard errors by both parent firm and year. Gray lines reflects the diff-in-diff estimate described in (1), located so the lower line corresponds to the average of pre-BTT event study coefficients. Both specifications include firm and industry $\times$ time fixed effects and a full set of controls, as in column (5) of Table 3 
Figure A3: Effect of BTTs on U.S. Multinational Firm Employment Using All BTTs in High Royalty, Interest, and Dividend Industries

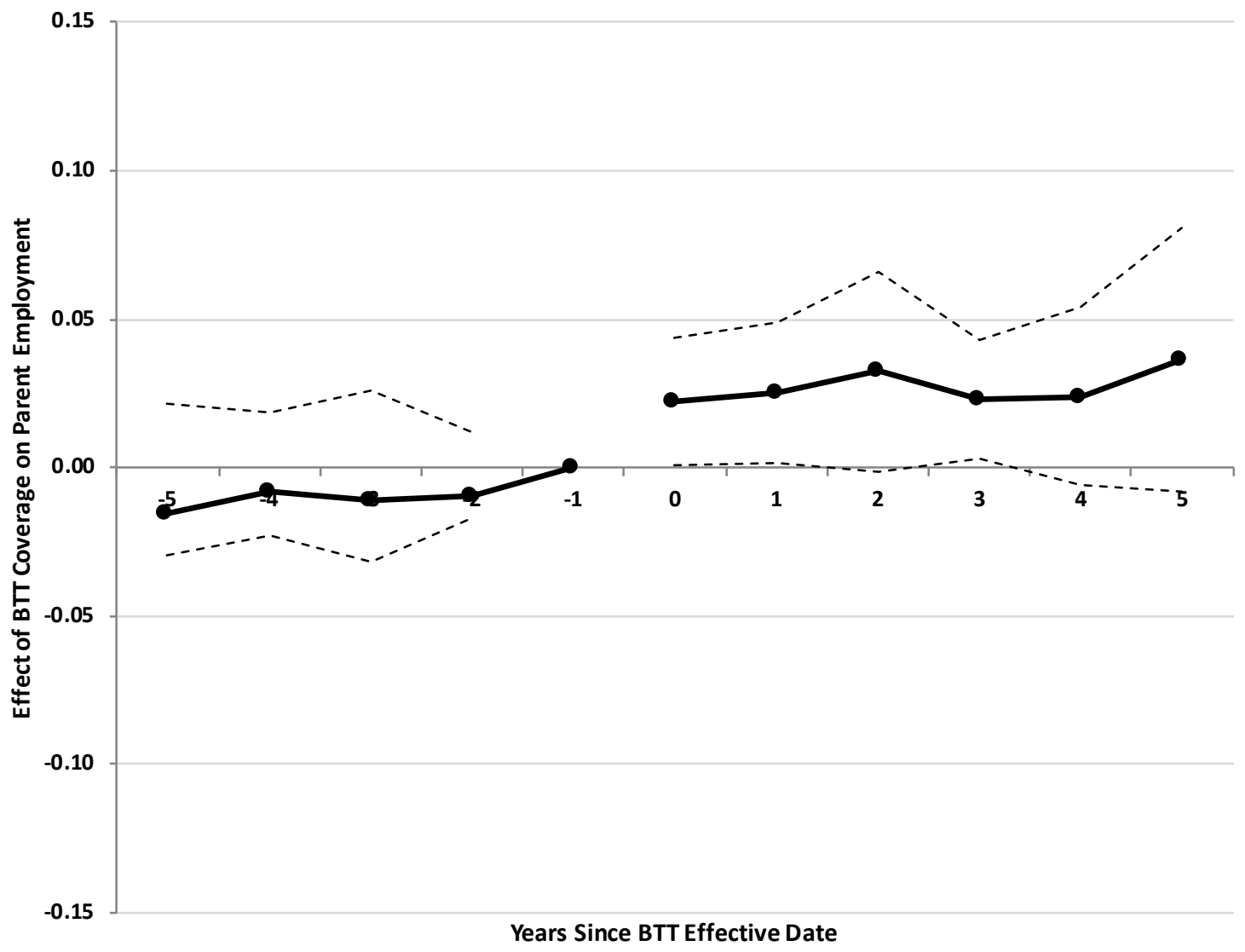

Source: Authors' calculations based on BEA Annual Surveys of U.S. Direct Investment Abroad 1987-2007. Sample restricted to firms in industries with high RID payments to U.S. parent firms. Each point on the black line represents a coefficient estimate on leads or lags of the BTT coverage measure in 15 . Dashed lines reflect 95 percent confidence intervals for these estimates when clustering standard errors by both parent firm and year. The regressions include firm and industry $\times$ time fixed effects and a full set of controls, as in column (5) of Table 3 


\section{A.4 Empirical Results Using Variation in the Change in With- holding Tax Rates}

This section presents all of the main empirical results utilizing additional variation in the magnitude of the withholding tax changes across the various countries signing new BTTs with the U.S. As shown in Table 1, the decline in withholding rate varied across treaties and across the relevant financial flows (royalties, interest, and dividends) for a given treaty. It is therefore plausible that countries whose affiliates faced larger declines in withholding tax rates would exhibit larger effects. Accounting for these differences might therefore improve the statistical power of our analysis.

The results of such an analysis appear in Tables A3- A8. We refer to the treaty-induced change in withholding tax rate as the "dosage" for affiliates in that country. In order to calculate this dosage measure, we made a number of decisions. First, the analysis presented here omits affiliates in Tunisia, Venezuela, Slovenia, and Bangladesh, since we do not have pre- and post-treaty tax rates for those countries (Table 1). This leaves us with 14 treated countries rather than the 18 we use in the main analysis. Second, in many cases withholding rates are reported as a range, rather than a specific value (see Table 1). We use the maximum possible change in the tax rate for each type of income (results based on the minimum possible change are extremely similar).

Third, since countries generally apply different withholding tax rates to each of the three different types of payments (royalties, interest, and dividends - RID), we weight these three financial flows by their importance for a given affiliate. In order to avoid endogeneity concerns in which withholding rates distort the size of each financial flow, we created country-level weights using data for RID payments from the 1989 BEA Benchmark Survey. However, the former Soviet republics in our sample did not exist in 1989, and most of them did not have RID payments in 1994, so we use data from 1999 for this set of countries (and 1989 for all others).

Fourth, after aggregating across royalty, interest, and dividend payments using the weights just described, we had to choose a functional form for how the change in average withholding tax rate influenced the size of the BTT's effects on employment outcomes. In Appendix B.1 equation (26), the withholding tax rate is parameterized as

$$
\ln \tau_{c t i}=\ln \left[\left(1+t-t_{c}^{*}\right)\left(1-\phi_{c i}\right)-h^{*} \phi_{c i}\right]
$$

where $h^{*}$ is the withholding tax rate. For simplicity, assume $t \approx t_{c}^{*}$ and $\phi_{c i} \approx 0.5$. With those assumptions,

$$
\ln \tau_{c t i} \approx \ln (0.5)+\ln \left(1-h^{*}\right)
$$

A BTT changes $h^{*}$, such that the change in the effective tax on offshore activity is

$$
d \ln \tau_{c t i} \approx d \ln \left(1-h^{*}\right)
$$

We use the righthand side of this expression as our measure of the magnitude of a given BTT. For example, if a country's withholding tax rate fell from $25 \%$ to $10 \%$, then the dosage measure will be $0.182=\ln (1-0.10)-\ln (1-0.25)$. One way to think about this measure is by noting that $\ln (1-x) \approx 1-x$ when $x$ is small. So, for small values of $h^{*}$, our 
measure is just the negative of the change in withholding tax rate.

Given these choices, we take the withholding tax rates from Table 1 and multiply the BTT indicator in the main analysis by this dosage measure. We then use this dosage-scaled BTT indicator in Tables A3 -A8. The affiliate-level first-stage analysis in Table A3 is indeed stronger, with larger partial F-statistics than in the main analysis. However, this difference in the first stage does not lead to substantive changes in the second-stage results at the parent, industry, or region level, showing that our findings are robust to utilizing variation in withholding tax changes across BTTs. Also note that even though the affiliate-level firststage coefficients are roughly ten times higher than the corresponding coefficients on the binary BTT treatment variable in Table 4 of the paper, the predicted effects are very similar across the two specifications, as the average "dosage" is approximately 0.1 . 
Table A3: Foreign Affiliate-Level Analysis:

The Effect of BTTs on Offshore Employment - Dosage Measure

Dependent variable: $\log$ affiliate employment: $\ln \left(m_{a t}\right)$

\begin{tabular}{|c|c|c|c|c|c|c|}
\hline Sample: & $\begin{array}{l}\text { (1) } \\
\text { All }\end{array}$ & $\begin{array}{c}(2) \\
\text { High RID }\end{array}$ & $\begin{array}{c}(3) \\
\text { Low RID }\end{array}$ & $\begin{array}{l}\text { (4) } \\
\text { All }\end{array}$ & $\begin{array}{c}(5) \\
\text { High RID }\end{array}$ & $\begin{array}{c}(6) \\
\text { Low RID }\end{array}$ \\
\hline BTT Dosage & $\begin{array}{c}3.003^{* * * *} \\
(0.614)\end{array}$ & $\begin{array}{c}3.694^{* * *} \\
(0.402)\end{array}$ & $\begin{array}{c}1.398^{* *} \\
(0.56)\end{array}$ & $\begin{array}{c}2.641^{* * *} \\
(0.672)\end{array}$ & $\begin{array}{c}3.466^{* * *} \\
(0.51)\end{array}$ & $\begin{array}{l}0.917 \\
(0.58)\end{array}$ \\
\hline $\ln \left(G D P_{u s}+G D P_{d}\right)$ & & & & $\begin{array}{l}2.749^{*} \\
(1.628)\end{array}$ & $\begin{array}{c}0.944 \\
(3.419)\end{array}$ & $\begin{array}{c}5.159^{* * * *} \\
(1.966)\end{array}$ \\
\hline $\ln \left(G D P_{u s}-G D P_{d}\right)^{2}$ & & & & $\begin{array}{c}0.07 \\
(0.122)\end{array}$ & $\begin{array}{c}0.021 \\
(0.166)\end{array}$ & $\begin{array}{c}0.198 \\
(0.169)\end{array}$ \\
\hline $\ln$ (Skill Difference) & & & & $\begin{array}{c}-0.077^{* * *} \\
(0.024)\end{array}$ & $\begin{array}{l}-0.047 \\
(0.113)\end{array}$ & $\begin{array}{c}-0.120^{* * * *} \\
(0.037)\end{array}$ \\
\hline $\ln ($ Trade Costs $)$ & & & & $\begin{array}{c}0.019^{* *} \\
(0.008)\end{array}$ & $\begin{array}{c}0.012 \\
(0.026)\end{array}$ & $\begin{array}{l}.031^{* *} \\
(0.012)\end{array}$ \\
\hline BIT & & & & $\begin{array}{c}-0.390^{* * *} \\
(0.085)\end{array}$ & $\begin{array}{l}-0.317 \\
(0.202)\end{array}$ & $\begin{array}{c}-0.489^{* * *} \\
(0.123)\end{array}$ \\
\hline FTA & & & & $\begin{array}{c}0.070^{* *} \\
(0.032)\end{array}$ & $\begin{array}{c}0.123 \\
(0.075)\end{array}$ & $\begin{array}{l}-0.022 \\
(0.043)\end{array}$ \\
\hline Exchange Rate & & & & $\begin{array}{r}-0.000008 \\
(0.00002)\end{array}$ & $\begin{array}{l}-0.00005 \\
(0.00005)\end{array}$ & $\begin{array}{r}-0.000008 \\
(0.00003)\end{array}$ \\
\hline Parent-Sibling BTTs & & & & $\begin{array}{c}-0.045^{* * *} \\
(0.139)\end{array}$ & $\begin{array}{c}-0.051^{* *} \\
(0.023)\end{array}$ & $\begin{array}{c}-0.036^{*} \\
(0.019)\end{array}$ \\
\hline Affiliate-Sibling BTTs & & & & $\begin{array}{l}0.129^{*} \\
(0.075)\end{array}$ & $\begin{array}{c}0.157^{* *} \\
(0.072)\end{array}$ & $\begin{array}{c}0.053 \\
(0.081)\end{array}$ \\
\hline Affiliate FE & YES & YES & YES & YES & YES & YES \\
\hline Industry-Year FE & YES & YES & YES & YES & YES & YES \\
\hline $\mathrm{N}$ & 337787 & 194727 & 143060 & 337787 & 194727 & 143060 \\
\hline R-sq & 0.0208 & 0.0322 & 0.0043 & 0.0255 & 0.0358 & 0.0139 \\
\hline F-Statistic & 23.89 & 84.51 & 6.23 & 23.62 & 50.91 & 7.08 \\
\hline
\end{tabular}

Notes: Documents the effect of newly-signed Bilateral Tax Treaties (BTTs) on foreign affiliate employment using the "dosage" measure described in the text. "High RID" and "Low RID" refer to firms within industries that exhibit ratios of total payments in royalties, interest, and dividends relative to total industry sales that are above and below the median sector. (see Appendix A.2 for details). Sample covers 1987-2007. Standard errors clustered by both affiliate country and year are in parentheses. $*, * *$, and $* * *$ indicate significance at the 10,5 , and 1 percent levels, respectively. 
Table A4: U.S. Parent-Level Analysis:

The Effect of Offshore Employment on Domestic MNE Employment - Dosage Measure

Dependent variable: log parent employment: $\ln \left(s_{f t}\right)$

\begin{tabular}{lcccc}
\hline \hline & $(1)$ & $(2)$ & $(3)$ & $(4)$ \\
Specification: & IV & IV & IV & IV \\
Sample: & All & All & New Aff & Cont Aff \\
\hline log affiliate employment: & $0.190^{* * *}$ & $0.144^{* * *}$ & 0.06 & $0.151^{* * *}$ \\
& $(0.019)$ & $(0.018)$ & $(0.170)$ & $(0.018)$ \\
$\ln \left(G D P_{u s}+G D P_{d}\right)$ & & -0.007 & -0.293 & -0.019 \\
& & $(0.092)$ & $(0.397)$ & $(0.088)$ \\
$\ln \left(G D P_{u s}-G D P_{d}\right)^{2}$ & & 0.001 & 0.127 & 0.009 \\
& & $(0.047)$ & $(0.207)$ & $(0.045)$ \\
$\ln ($ Skill Difference $)$ & & $-0.099^{* *}$ & 0.096 & $-0.120^{* *}$ \\
& & $(0.045)$ & $(0.110)$ & $(0.047)$ \\
$\ln ($ Trade Costs $)$ & & -0.017 & 0.017 & -0.02 \\
& & $(0.013)$ & $(0.035)$ & $(0.014)$ \\
BIT & & $-0.468^{* * *}$ & -0.355 & $-0.513^{* *}$ \\
& & $(0.171)$ & $(0.227)$ & $(0.209)$ \\
FTA & & -0.005 & 0.082 & -0.012 \\
& & $(0.048)$ & $(0.127)$ & $(0.053)$ \\
Exchange Rate & & -0.00005 & 0.00001 & -0.00008 \\
& & $(0.000)$ & $(0.000)$ & $(0.000)$ \\
\hline Parent FE & & YES & YES & YES \\
Year FE & YES & YES & YES & YES \\
N & YES & 29765 & 6077 & 23688 \\
R-sq & 29765 & 0.1576 & 0.3427 & 0.1663 \\
First Stage F-Stat & 0.1358 & 356.85 & 10.41 & 351.67 \\
Endog Test P-Val & 335.28 & 0.0018 & 0.0026 & 0.0014 \\
\hline \hline
\end{tabular}

Notes: Documents the effects of BTT-induced changes in foreign-affiliate employment on domestic employment of multinational firms in industries that exhibit high ratios of royalty, interest, and dividend payments relative to total industry sales, using the "dosage" measure described in the text. Columns (5) and (6) respectively restrict the sample to parent firms that did and did not open new affiliates in countries newly receiving a BTT. First-stage F-statistics are large for all IV specifications, though the relevant F-statistics for weak-instrument concerns appear in columns (2) and (5) of Table A3 (see text for discussion). In all IV specifications, the equality of OLS and IV is rejected. Sample covers 1987-2007. Standard errors clustered by parent firm and year are in parentheses. ${ }^{* *}$, and ${ }^{* * *}$ indicate significance at the 10,5 , and 1 percent levels, respectively. 
Table A5: U.S. Industry-Level Analysis:

The Effect of Offshore Employment on U.S. Industry Employment - Dosage Measure

Dependent variable: $\log$ industry employment: $\ln \left(L_{i t}\right)$

\begin{tabular}{lcc}
\hline \hline & $(1)$ & $(2)$ \\
Specification: & IV & IV \\
\hline industry log affiliate employment: & $0.007^{* * *}$ & $0.008^{* * *}$ \\
& $(0.003)$ & $(0.003)$ \\
$\ln \left(G D P_{u s}+G D P_{d}\right)$ & & -0.013 \\
& & $(0.036)$ \\
$\ln \left(G D P_{u s}-G D P_{d}\right)^{2}$ & & 0.004 \\
& & $(0.018)$ \\
$\ln ($ Skill Difference $)$ & & 0.01 \\
& & $(0.018)$ \\
$\ln ($ Trade Costs) & & $0.011^{* *}$ \\
& & $(0.005)$ \\
BIT & & -0.005 \\
& & $(0.021)$ \\
FTA & & 0.013 \\
& & $(0.016)$ \\
Exchange Rate & & -0.00003 \\
& & $(0.000)$ \\
\hline Industry FE & YES & YES \\
Year FE & YES & YES \\
N & 1268 & 1268 \\
R-sq & 0.4796 & 0.5252 \\
First Stage F-Stat & 200.08 & 106.93 \\
Endog Test P-Val & 0.0254 & 0.0298 \\
\hline \hline
\end{tabular}

Notes: Documents the effects of BTT-induced changes in foreign-affiliate employment at the industry level for industries that exhibit high ratios of royalty, interest, and dividend payments relative to total industry sales, using the "dosage" measure described in the text. First-stage F-statistics are large for all IV specifications, though the relevant F-statistics for weak-instrument concerns appear in columns (2) and (5) of Table A3 (see text for discussion). In all IV specifications, the equality of OLS and IV is rejected. Sample covers 1987-2007. Standard errors clustered by industry and year are in parentheses. ${ }^{*}, * *$, and $* * *$ indicate significance at the 10,5 , and 1 percent levels, respectively. 
Table A6: U.S. Industry Level Analysis:

The Effect of Offshore Employment on U.S. MNE vs. non-MNE Employment - Dosage Measure

Dependent variable: $\log$ industry employment: $\ln \left(L_{i t}\right)$

\begin{tabular}{lcccc}
\hline \hline & $(1)$ & $(2)$ & $(3)$ & $(4)$ \\
Specification: & IV & IV & IV & IV \\
Sample: & MNE & MNE & non-MNE & non-MNE \\
\hline industry log affiliate employment: & $0.044^{* * *}$ & $0.044^{* * *}$ & 0.002 & 0.001 \\
& $(0.005)$ & $(0.005)$ & $(0.004)$ & $(0.005)$ \\
$\ln \left(G D P_{u s}+G D P_{d}\right)$ & & 0.101 & & -0.029 \\
$\ln \left(G D P_{u s}-G D P_{d}\right)^{2}$ & & $(0.092)$ & & $(0.046)$ \\
& & -0.05 & & 0.012 \\
$\ln ($ Skill Difference) & & $(0.047)$ & & $(0.024)$ \\
& & -0.06 & & 0.014 \\
$\ln ($ Trade Costs) & & $(0.037)$ & & $(0.022)$ \\
& & -0.007 & & 0.011 \\
BIT & & $(0.007)$ & & $(0.009)$ \\
& & 0.047 & & -0.007 \\
FTA & & $(0.067)$ & & $0.026)$ \\
& & 0.06 & & 0.015 \\
Exchange Rate & & $(0.037)$ & & $(0.016)$ \\
& & -0.00002 & & -0.00001 \\
Industry FE & & $(0.000)$ & & $(0.000)$ \\
Year FE & YES & YES & YES \\
N & YES & YES & YES & YES \\
R-sq & 1268 & 1268 & 1268 & 1268 \\
First Stage F-Stat & 0.2555 & 0.2984 & 0.4236 & 0.4697 \\
Endog Test P-Val & 151.44 & 82.25 & 182.04 & 98.39 \\
\hline \hline & 0.0091 & 0.0053 & 0.0201 & 0.0189 \\
\hline
\end{tabular}

Notes: Documents the effects of BTT-induced changes in foreign-affiliate employment at the industry level for industries that exhibit high ratios of royalty, interest, and dividend payments relative to total industry sales, using the "dosage" measure described in the text. Columns (1) and (2) examine employment for multinational parents in the U.S. industry while columns (3) and (4) examine all other employment in each industry. First-stage F-statistics are large for all IV specifications, though the relevant F-statistics for weak-instrument concerns appear in columns (2) and (5) of Table A3 (see text for discussion). In all IV specifications, the equality of OLS and IV is rejected. Sample covers 1987-2007. Standard errors clustered by industry and year are in parentheses. $* * *$, and $* * *$ indicate significance at the 10,5 , and 1 percent levels, respectively. 
Table A7: U.S. Industry Level Analysis:

The Effect of Offshore Employment at Vertically Oriented Affiliates on U.S. MNE vs. non-MNE Employment - Dosage Measure

Dependent variable: $\log$ industry employment: $\ln \left(L_{i t}\right)$

\begin{tabular}{lcccc}
\hline \hline & $(1)$ & $(2)$ & $(3)$ & $(4)$ \\
Specification: & IV & IV & IV & IV \\
Sample: & V-MNE & V-MNE & non-MNE & non-MNE \\
\hline industry log affiliate employment: & $0.156^{* * *}$ & $0.149^{* * *}$ & -0.009 & $-0.016^{* *}$ \\
& $(0.008)$ & $(0.008)$ & $(0.008)$ & $(0.008)$ \\
$\ln \left(G D P_{u s}+G D P_{d}\right)$ & & $-0.364^{*}$ & & -0.289 \\
& & $(0.191)$ & & $(0.193)$ \\
$\ln \left(G D P_{u s}-G D P_{d}\right)^{2}$ & & $0.203^{* *}$ & & 0.141 \\
& & $(0.096)$ & & $(0.097)$ \\
$\ln ($ Skill Difference) & & $-0.429^{* * *}$ & & 0.042 \\
& & $(0.061)$ & & $(0.065)$ \\
$\ln ($ Trade Costs $)$ & & -0.006 & & -0.002 \\
& & $(0.016)$ & & $(0.016)$ \\
BIT & & -0.036 & & $0.444^{*}$ \\
& & $(0.266)$ & & $(0.233)$ \\
FTA & & -0.02 & & $0.130^{*}$ \\
& & $(0.066)$ & & $(0.069)$ \\
Exchange Rate & & 0.0002 & & 0.00009 \\
& & $(0.000)$ & & $(0.000)$ \\
\hline Industry FE & & YES & YES & YES \\
Year FE & YES & YES & YES & YES \\
N & 1217 & 1217 & 1217 & 1217 \\
R-sq & 0.1301 & 0.1654 & 0.4532 & 0.5019 \\
First Stage F-Stat & 339.61 & 241.63 & 301.56 & 309.69 \\
Endog Test P-Val & 0.0091 & 0.0066 & 0.0191 & 0.0174 \\
\hline \hline
\end{tabular}

Notes: Documents the effects of BTT-induced changes in foreign-affiliate employment at foreign affiliates that have non-zero sales to their U.S. parent on domestic employment at the industry level for industries that exhibit high ratios of royalty, interest, and dividend payments relative to total industry sales, using the "dosage" measure described in the text. Columns (1) and (2) examine employment for multinational parents in the U.S. industry while columns (3) and (4) examine all other employment in each industry. First-stage F-statistics are large for all IV specifications, though the relevant F-statistics for weak-instrument concerns appear in columns (2) and (5) of Table A3 (see text for discussion). In all IV specifications, the equality of OLS and IV is rejected. Sample covers 1987-2007. Standard errors clustered by industry and year are in parentheses. ${ }^{*}, * *$, and $* * *$ indicate significance at the 10,5 , and 1 percent levels, respectively. 
Table A8: U.S. Metro Area Level Analysis:

The Effect of Offshore Employment on U.S. Regional Employment - Dosage Measure

Dependent variable: $\log$ regional employment: $\ln \left(L_{m t}\right)$

\begin{tabular}{lcc}
\hline \hline & $(1)$ & $(2)$ \\
Specification: & IV & IV \\
\hline regional log affiliate employment: & $0.025^{* *}$ & $0.026^{* * *}$ \\
$\ln \left(G D P_{u s}+G D P_{d}\right)$ & $(0.005)$ & $(0.005)$ \\
& & $0.137^{*}$ \\
$\ln \left(G D P_{u s}-G D P_{d}\right)^{2}$ & & $(0.076)$ \\
& & $-0.029^{* *}$ \\
$\ln ($ Skill Difference $)$ & & $(0.015)$ \\
& & $0.107^{* *}$ \\
$\ln ($ Trade Costs $)$ & & $(0.052)$ \\
& & 0.03 \\
BIT & & $(0.025)$ \\
& & 0.226 \\
FTA & & $0.205)$ \\
& & 0.052 \\
Exchange Rate & & $(0.035)$ \\
& & -0.00002 \\
Industry FE & & $(0.000)$ \\
Year FE & YES & YES \\
N & YES & YES \\
R-sq & 6080 & 6080 \\
First Stage F-Stat & 0.7312 & 0.7387 \\
Endog Test P-Val & 72.97 & 91.22 \\
\hline \hline
\end{tabular}

Notes: Documents the effects of BTT-induced changes in foreign-affiliate employment on domestic employment at the region level, using the "dosage" measure described in the text. First-stage F-statistics are large for all IV specifications, though the relevant F-statistics for weak-instrument concerns appear in columns (2) and (5) of Table A3 (see text for discussion). In all IV specifications, the equality of OLS and IV is rejected. Sample covers 1987-2007. Standard errors clustered by parent firm and year are in parentheses. $*^{* *}$, and ${ }^{* * *}$ indicate significance at the 10,5 , and 1 percent levels, respectively. 


\section{A.5 Empirical Results for Vertically Oriented Multinational Firms}

This appendix replicates the empirical results in the main text for a subsample of vertically oriented multinational firms, i.e. those whose foreign affiliates exhibit sales back to the U.S. parent. The results are similar to those in the main text, which use the full sample of multinationals irrespective of vertical or horizontal orientation. One exception is the industry-level effect of offshoring activity on non-multinational firm employment, which is why we include the effects for vertically oriented firms in Table 8 in the main text and discuss the differences in Section 4.2.3.

For reference, Appendix Figure A4 corresponds to Figure 1 in the main text, Table A9 corresponds to Table 2, Table A10 corresponds to Table 3, Table A11 corresponds to Table 4. Table A12 corresponds to Table 5, Table A13 corresponds to Table 6, and Table A14 corresponds to Table 9 . 
Figure A4: Effect of BTTs on Vertically Oriented U.S. Multinational Firm Employment in High Royalty, Interest, and Dividend Industries

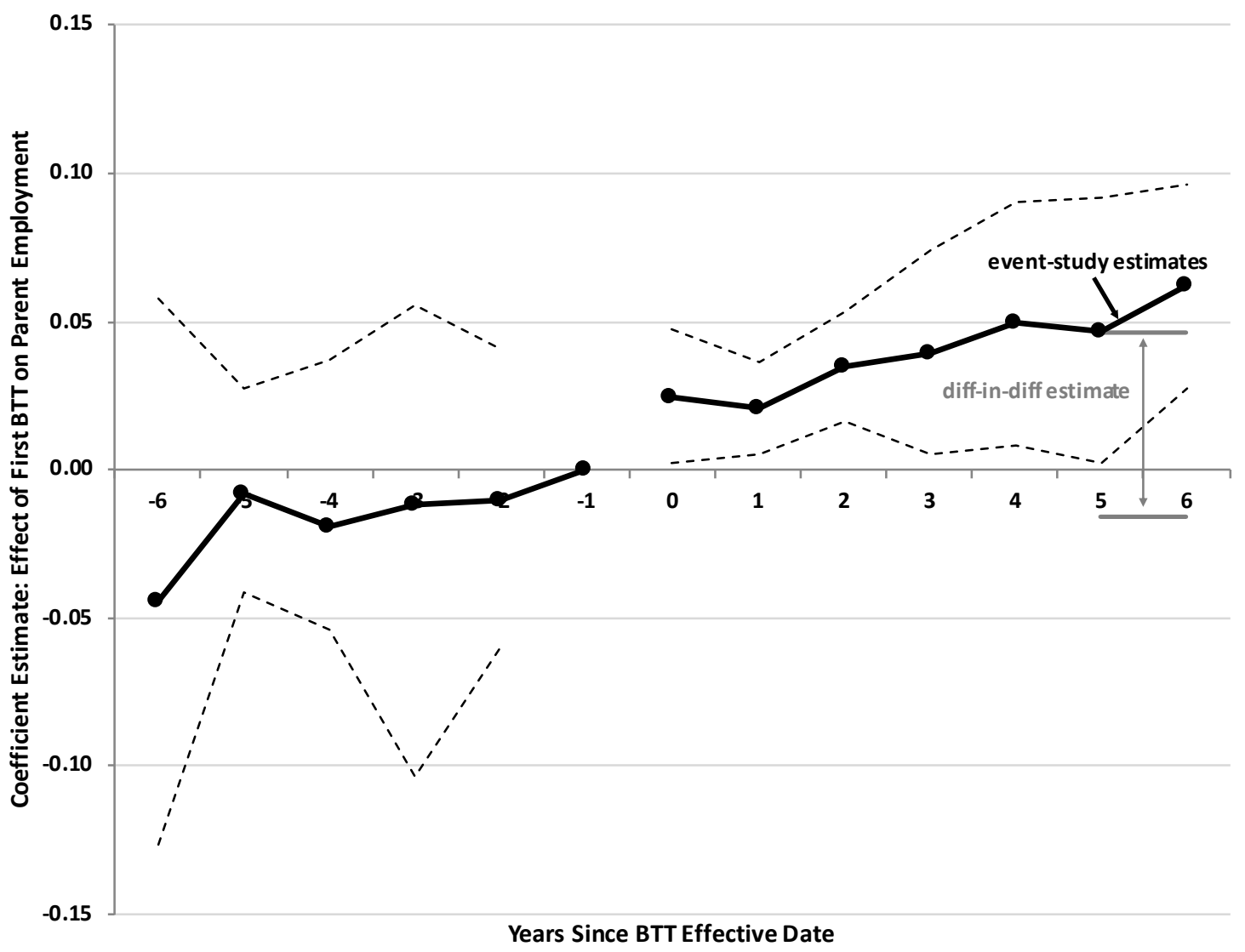

Source: Authors' calculations based on BEA Annual Surveys of U.S. Direct Investment Abroad. Sample restricted to firms in industries with high royalty, interest, and dividend payments. Each point on the black line represents a coefficient estimate from the event study specification in (2). Dashed lines reflect 95 percent confidence intervals for these event-study estimates when clustering standard errors by both parent firm and year. Gray lines reflects the diff-in-diff estimate described in (1), located so the lower line corresponds to the average of pre-BTT event study coefficients. Both specifications include firm and industry $\times$ time fixed effects and a full set of controls, as in column (5) of Table 3 
Table A9: Summary Statistics for Vertically Oriented Multinational Firms

\begin{tabular}{|c|c|c|c|c|}
\hline & Mean & Std. Dev. & Min & $\operatorname{Max}$ \\
\hline \multicolumn{5}{|c|}{ FOREIGN AFFILIATES (107,458 obs.) } \\
\hline Employment & 647.65 & 2158.0 & \multicolumn{2}{|c|}{ (confidential) } \\
\hline $\ln ($ Employment $)$ & 4.8569 & 1.9544 & \multicolumn{2}{|c|}{ (confidential) } \\
\hline Av. Annual Emp Growth (\%) & 0.1074 & 0.8576 & \multicolumn{2}{|c|}{ (confidential) } \\
\hline BTT & 0.8315 & 0.3743 & 0 & 1 \\
\hline High RID Indicator & 0.5481 & 0.4977 & 0 & 1 \\
\hline $\ln \left(G D P_{u s}+G D P_{d}\right)$ & 9.3503 & 0.215 & 8.8665 & 10.093 \\
\hline $\ln \left(G D P_{u s}-G D P_{d}\right)^{2}$ & 18.219 & 0.5496 & 14.841 & 18.933 \\
\hline ln(Skill Difference) & 1.0233 & 0.7481 & 0 & 2.4850 \\
\hline $\ln ($ Trade Cost $)$ & 2.6179 & 2.3767 & 0 & 4.4888 \\
\hline BIT & 0.0384 & 0.1921 & 0 & 1 \\
\hline FTA & 0.1712 & 0.3767 & 0 & 1 \\
\hline Exchange Rate & 115.44 & 762.15 & 0 & 16105 \\
\hline Parent-Sibling BTTs ${ }^{a}$ & 0.5513 & 0.2010 & 0 & 1 \\
\hline Affiliate-Sibling BTTs ${ }^{b}$ & 0.2935 & 0.3797 & 0 & 3.3712 \\
\hline \multicolumn{5}{|l|}{ U.S. PARENT FIRMS (26,418 obs.) } \\
\hline Foreign Affiliate Employment & 2778.4 & 10855 & \multicolumn{2}{|c|}{ (confidential) } \\
\hline $\ln ($ Aff Emp) & 5.9015 & 2.1264 & \multicolumn{2}{|c|}{ (confidential) } \\
\hline Av Annual Aff Emp Growth (\%) & 0.1355 & 0.8722 & \multicolumn{2}{|c|}{ (confidential) } \\
\hline Parent Firm Employment & 9236.3 & 28622 & \multicolumn{2}{|c|}{ (confidential) } \\
\hline $\ln$ (Parent Employment) & 7.5790 & 1.9188 & \multicolumn{2}{|c|}{ (confidential) } \\
\hline Number of Affiliates & 4.5014 & 7.3598 & \multicolumn{2}{|c|}{ (confidential) } \\
\hline $\ln \left(G D P_{u s}+G D P_{d}\right)^{c}$ & 4.0454 & 3.5220 & 0 & 29.618 \\
\hline $\ln \left(G D P_{u s}-G D P_{d}\right)^{2 c}$ & 7.8928 & 6.8857 & 0 & 58.087 \\
\hline $\ln (\text { Skill Difference })^{c}$ & 0.4125 & 0.4980 & 0 & 4.1650 \\
\hline $\ln (\text { Trade Cost })^{c}$ & 1.2377 & 1.5908 & 0 & 10.328 \\
\hline $\mathrm{BIT}^{c}$ & 0.0048 & 0.0560 & 0 & 1 \\
\hline $\mathrm{FTA}^{c}$ & 0.1437 & 0.3116 & 0 & 1 \\
\hline Exchange Rate $^{c}$ & 17.835 & 178.47 & 0 & 23574 \\
\hline
\end{tabular}

Authors' calculations from BEA Annual Surveys of U.S. Direct Investment Abroad and various other data sources, described in Section $2{ }^{a}$ Weighted average share of total sibling employment covered by a BTT with the U.S., using fixed affiliate employment shares. ${ }^{b}$ Weighted average share of total sibling employment covered by a BTT with the affiliate's country, using fixed affiliate employment shares. ${ }^{c}$ Parent-level versions of affiliate country controls are aggregated from the country to the parent firm level using a weighted average, using fixed affiliate employment shares as weights. 
Table A10: Reduced Form Difference-in-Differences Analysis:

The Effect of BTTs on Parent Employment, Vertically Oriented Firms

Dependent variable: $\log$ parent employment: $\ln \left(s_{f t}\right)$

\begin{tabular}{|c|c|c|c|c|c|c|}
\hline Sample: & $\begin{array}{l}(1) \\
\text { All } \\
\end{array}$ & $\begin{array}{c}(2) \\
\text { High RID }\end{array}$ & $\begin{array}{c}(3) \\
\text { Low RID }\end{array}$ & $\begin{array}{l}(4) \\
\text { All } \\
\end{array}$ & $\begin{array}{c}(5) \\
\text { High RID }\end{array}$ & $\begin{array}{c}(6) \\
\text { Low RID }\end{array}$ \\
\hline $\operatorname{BTT}\left[\tilde{\varphi}_{f} \mathbf{1}\left(t \geq \tilde{t}_{f}\right)\right]$ & $\begin{array}{c}0.011 \\
(0.014)\end{array}$ & $\begin{array}{c}0.034^{* *} \\
(0.017)\end{array}$ & $\begin{array}{c}-0.014 \\
(0.022)\end{array}$ & $\begin{array}{c}0.013 \\
(0.019)\end{array}$ & $\begin{array}{c}0.046^{* * *} \\
(0.012)\end{array}$ & $\begin{array}{l}-0.015 \\
(0.062)\end{array}$ \\
\hline $\ln \left(G D P_{u s}+G D P_{d}\right)$ & & & & $\begin{array}{l}0.722^{*} \\
(0.413)\end{array}$ & $\begin{array}{c}1.649 \\
(1.307)\end{array}$ & $\begin{array}{c}0.244 \\
(0.986)\end{array}$ \\
\hline $\ln \left(G D P_{u s}-G D P_{d}\right)^{2}$ & & & & $\begin{array}{c}-0.388^{*} \\
(0.209)\end{array}$ & $\begin{array}{l}-0.275 \\
(0.655)\end{array}$ & $\begin{array}{l}-2.381 \\
(1.932)\end{array}$ \\
\hline $\ln ($ Skill Difference) & & & & $\begin{array}{l}-0.006 \\
(0.041)\end{array}$ & $\begin{array}{c}-0.731^{* *} \\
(0.288)\end{array}$ & $\begin{array}{c}0.733 \\
(0.65)\end{array}$ \\
\hline $\ln ($ Trade Costs $)$ & & & & $\begin{array}{c}0.541 \\
(0.704)\end{array}$ & $\begin{array}{l}-0.782 \\
(0.966)\end{array}$ & $\begin{array}{c}0.127 \\
(0.286)\end{array}$ \\
\hline $\mathrm{BIT}$ & & & & $\begin{array}{c}0.577 \\
(0.389)\end{array}$ & $\begin{array}{l}-0.405 \\
(0.308)\end{array}$ & $\begin{array}{l}-0.623 \\
(1.069)\end{array}$ \\
\hline FTA & & & & $\begin{array}{c}0.314 \\
(0.793)\end{array}$ & $\begin{array}{l}-0.374 \\
(0.328)\end{array}$ & $\begin{array}{c}0.721 \\
(1.499)\end{array}$ \\
\hline Exchange Rate & & & & $\begin{array}{c}0.000 \\
(0.002)\end{array}$ & $\begin{array}{c}0.000 \\
(0.0002)\end{array}$ & $\begin{array}{c}0.000 \\
(0.002)\end{array}$ \\
\hline Parent FE & YES & YES & YES & YES & YES & YES \\
\hline Industry-Year FE & YES & YES & YES & YES & YES & YES \\
\hline $\mathrm{N}$ & 26418 & 15092 & 11326 & 26418 & 15092 & 11326 \\
\hline R-sq & 0.0894 & 0.1137 & 0.0732 & 0.1023 & 0.1481 & 0.0896 \\
\hline
\end{tabular}

Notes: Documents the effect of newly-signed Bilateral Tax Treaties (BTTs) on parent employment in U.S. multinational enterprises. "High RID" and "Low RID" refer to firms within industries that exhibit ratios of total payments in royalties, interest and dividends relative to total industry sales that are above and below the median sector (see Appendix A.2 for details). Standard errors clustered by both parent firm and year are in parentheses. ${ }^{*}, * *$, and ${ }^{* * *}$ indicate significance at the 10,5 , and 1 percent levels, respectively. 
Table A11: Foreign Affiliate-Level Analysis:

The Effect of BTTs on Offshore Employment, Vertically Oriented Firms

Dependent variable: $\log$ affiliate employment: $\ln \left(m_{a t}\right)$

\begin{tabular}{|c|c|c|c|c|c|c|}
\hline Sample: & $\begin{array}{l}\text { (1) } \\
\text { All }\end{array}$ & $\begin{array}{c}(2) \\
\text { High RID }\end{array}$ & $\begin{array}{c}(3) \\
\text { Low RID }\end{array}$ & $\begin{array}{l}\text { (4) } \\
\text { All }\end{array}$ & $\begin{array}{c}(5) \\
\text { High RID }\end{array}$ & $\begin{array}{c}(6) \\
\text { Low RID }\end{array}$ \\
\hline BTT & $\begin{array}{c}0.133 \\
(0.082)\end{array}$ & $\begin{array}{c}0.337^{* * *} \\
(0069)\end{array}$ & $\begin{array}{l}-0.083 \\
(0.139)\end{array}$ & $\begin{array}{l}0.085 \\
(0.085)\end{array}$ & $0.312^{* * *}$ & $\begin{array}{l}-0.152 \\
(0113)\end{array}$ \\
\hline $\ln \left(G D P_{u s}+G D P_{d}\right)$ & & & & $\begin{array}{c}1.302 \\
(2.826)\end{array}$ & $\begin{array}{l}-2.958 \\
(3.649)\end{array}$ & $\begin{array}{c}6.943^{* * *} \\
(2.334)\end{array}$ \\
\hline $\ln \left(G D P_{u s}-G D P_{d}\right)^{2}$ & & & & $\begin{array}{c}0.079 \\
(0.171)\end{array}$ & $\begin{array}{l}-0.222 \\
(0.186)\end{array}$ & $\begin{array}{c}0.478^{* *} \\
(0.198)\end{array}$ \\
\hline $\ln ($ Skill Difference $)$ & & & & $\begin{array}{l}-0.122 \\
(0.095)\end{array}$ & $\begin{array}{l}-0.096 \\
(0.121)\end{array}$ & $\begin{array}{c}-0.161^{* *} \\
(0.072)\end{array}$ \\
\hline $\ln$ (Trade Costs) & & & & $\begin{array}{c}0.035 \\
(0.039)\end{array}$ & $\begin{array}{c}0.02 \\
(0.040)\end{array}$ & $\begin{array}{c}0.053 \\
(0.039)\end{array}$ \\
\hline BIT & & & & $\begin{array}{c}-0.907^{* *} \\
(0.416)\end{array}$ & $\begin{array}{c}-0.889^{* *} \\
(0.383)\end{array}$ & $\begin{array}{r}-0.947^{*} \\
(0.489)\end{array}$ \\
\hline FTA & & & & $\begin{array}{c}0.061 \\
(0.064)\end{array}$ & $\begin{array}{c}0.135 \\
(0.073)\end{array}$ & $\begin{array}{l}-0.032 \\
(0.062)\end{array}$ \\
\hline Exchange Rate & & & & $\begin{array}{l}-0.0001 \\
(0.0001)\end{array}$ & $\begin{array}{l}-0.0001 \\
(0.0001)\end{array}$ & $\begin{array}{l}-0.0001 \\
(0.0001)\end{array}$ \\
\hline Parent-Sibling BTTs & & & & $\begin{array}{c}-0.031^{* *} \\
(0.013)\end{array}$ & $\begin{array}{c}-0.038^{* * * *} \\
(0.008)\end{array}$ & $\begin{array}{l}-0.025 \\
(0.032)\end{array}$ \\
\hline Affiliate-Sibling BTTs & & & & $\begin{array}{c}0.076 \\
(0.053)\end{array}$ & $\begin{array}{c}0.051 \\
(0.032)\end{array}$ & $\begin{array}{l}0.109^{*} \\
(0.065)\end{array}$ \\
\hline Affiliate FE & YES & YES & YES & YES & YES & YES \\
\hline Industry-Year FE & YES & YES & YES & YES & YES & YES \\
\hline $\mathrm{N}$ & 107458 & 59775 & 47683 & 107458 & 59775 & 47683 \\
\hline R-sq & 0.0005 & 0.0028 & 0.0002 & 0.0135 & 0.0154 & 0.0222 \\
\hline F-Statistic & 2.61 & 21.86 & 0.35 & 8.97 & 23.18 & 5.36 \\
\hline
\end{tabular}

Notes: Documents the effect of newly-signed Bilateral Tax Treaties (BTTs) on foreign affiliate employment. "High RID" and "Low RID" refer to firms within industries that exhibit ratios of total payments in royalties, interest and dividends relative to total industry sales that are above and below the median sector (see Appendix A.2 for details). Standard errors clustered by both affiliate country and year are in parentheses. ${ }^{* * *}$, and $*^{* *}$ indicate significance at the 10,5 , and 1 percent levels, respectively. 
Table A12: U.S. Parent-Level Analysis:

The Effect of Offshore Employment on Domestic MNE Employment, Vertically Oriented Firms

Dependent variable: $\log$ parent employment: $\ln \left(s_{f t}\right)$

\begin{tabular}{lcccccc}
\hline \hline & $(1)$ & $(2)$ & $(3)$ & $(4)$ & $(5)$ & $(6)$ \\
Specification: & OLS & OLS & IV & IV & IV & IV \\
Sample: & & All & All & All & New Aff & Cont Aff \\
\hline log affiliate employment: & $0.285^{* * *}$ & $0.264^{* * *}$ & $0.120^{* * *}$ & $0.089^{* * *}$ & $0.056^{* *}$ & $0.102^{* * *}$ \\
& $(0.021)$ & $(0.019)$ & $(0.019)$ & $(0.015)$ & $(0.029)$ & $(0.016)$ \\
$\ln \left(G D P_{u s}+G D P_{d}\right)$ & & -0.281 & & -0.198 & -0.309 & $-0.297^{*}$ \\
& & $(0.203)$ & & $(0.144)$ & $(0.226)$ & $(0.164)$ \\
$\ln \left(G D P_{u s}-G D P_{d}\right)^{2}$ & & 0.084 & & 0.091 & 0.153 & 0.133 \\
& & $(0.102)$ & & $(0.073)$ & $(0.116)$ & $(0.082)$ \\
$\ln ($ Skill Difference) & & -0.026 & & -0.093 & $-0.152^{*}$ & 0.082 \\
& & $(0.098)$ & & $(0.079)$ & $(0.089)$ & $(0.139)$ \\
$\ln ($ Trade Costs) & & 0.002 & & 0.002 & 0.018 & -0.024 \\
& & $(0.022)$ & & $(0.016)$ & $(0.016)$ & $(0.025)$ \\
BIT & & $-0.932^{*}$ & & $-0.814^{*}$ & $-0.831^{* *}$ & 0.439 \\
& & $(0.498)$ & & $(0.489)$ & $(0.419)$ & $(0.813)$ \\
FTA & & -0.155 & & $-0.129^{*}$ & -0.056 & $-0.285^{*}$ \\
& & $(0.108)$ & & $(0.069)$ & $(0.071)$ & $(0.160)$ \\
Exchange Rate & & 0.0006 & & 0.00016 & 0.00001 & -0.00002 \\
& & $(0.000)$ & & $(0.0003)$ & $(0.0001)$ & $(0.0001)$ \\
\hline Parent FE & YES & YES & YES & YES & YES & YES \\
Year FE & YES & YES & YES & YES & YES & YES \\
N & 15092 & 15092 & 15092 & 15092 & 4678 & 10414 \\
R-sq & 0.1722 & 0.2646 & 0.1589 & 0.1779 & 0.2771 & 0.2295 \\
First Stage F-Stat & - & - & 412.66 & 443.21 & 206.88 & 341.83 \\
Endog Test P-Val & - & - & 0.0089 & 0.0081 & 0.0096 & 0.0084 \\
\hline \hline
\end{tabular}

Notes: Documents the effects of BTT-induced changes in foreign-affiliate employment on domestic employment of multinational firms in high RID industries. Columns (5) and (6) respectively restrict the sample to parent firms that did and did not open new affiliates in countries newly receiving a BTT. First-stage F-statistics are large for all IV specifications, though the relevant F-statistics for weak-instrument concerns appear in columns (2) and (5) of Table 4 (see text for discussion). In all IV specifications, the equality of OLS and IV is rejected. Standard errors clustered by parent firm and year are in parentheses. $*, * *$, and ${ }^{* * *}$ indicate significance at the 10,5 , and 1 percent levels, respectively. 
Table A13: U.S. Industry-Level Analysis:

The Effect of Offshore Employment on U.S. Industry Employment, Vertically Oriented Firms

Dependent variable: $\log$ industry employment: $\ln \left(L_{i t}\right)$

\begin{tabular}{lcccc}
\hline \hline & $(1)$ & $(2)$ & $(3)$ & $(4)$ \\
Specification: & OLS & OLS & IV & IV \\
\hline $\log$ affiliate employment: & $0.024^{* *}$ & $0.015^{* *}$ & 0.005 & 0.003 \\
$\left(\ln M_{i t}\right)$ & $(0.011)$ & $(0.007)$ & $(0.004)$ & $(0.004)$ \\
$\ln \left(G D P_{u s}+G D P_{d}\right)$ & & $-0.253^{*}$ & & $-0.157^{*}$ \\
& & $(0.136)$ & & $(0.084)$ \\
$\ln \left(G D P_{u s}-G D P_{d}\right)^{2}$ & & $0.120^{*}$ & & $0.074^{*}$ \\
& & $(0.068)$ & & $(0.042)$ \\
$\ln ($ Skill Difference) & & 0.863 & & 0.054 \\
& & $(0.550)$ & & $(0.037)$ \\
$\ln ($ Trade Costs) & & 0.078 & & 0.005 \\
& & $(0.069)$ & & $(0.004)$ \\
BIT & & 0.728 & & 0.045 \\
& & $(0.958)$ & & $(0.059)$ \\
FTA & & 0.774 & & 0.048 \\
& & $(0.563)$ & & $(0.035)$ \\
Exchange Rate & & 0.0004 & & 0.00002 \\
& & $(0.0002)$ & & $(0.0000)$ \\
\hline Industry FE & YES & YES & YES & YES \\
Year FE & YES & YES & YES & YES \\
$N$ & 1217 & 1217 & 1217 & 1217 \\
R-sq & 0.5061 & 0.5832 & 0.5095 & 0.5679 \\
First Stage F-Stat & - & - & 293.18 & 249.28 \\
Endog Test P-Val & - & - & 0.0029 & 0.0031 \\
\hline \hline
\end{tabular}

Notes: Documents the effects of BTT-induced changes in foreign-affiliate employment on domestic employment at the industry level for high RID industries. First-stage F-statistics are large for all IV specifications, though the relevant F-statistics for weak-instrument concerns appear in columns (2) and (5) of Table 4 (see text for discussion). In all IV specifications, the equality of OLS and IV is rejected. Standard errors clustered by industry and year are in parentheses. *,*, and *** indicate significance at the 10,5 , and 1 percent levels, respectively. 
Table A14: U.S. Metro Area Level Analysis:

The Effect of Offshore Employment on U.S. Regional Employment, Vertically Oriented Firms

Dependent variable: $\log$ regional employment: $\ln \left(L_{m t}\right)$

\begin{tabular}{|c|c|c|c|c|}
\hline Specification: & $\begin{array}{l}(1) \\
\text { OLS }\end{array}$ & $\begin{array}{c}(2) \\
\text { OLS }\end{array}$ & $\begin{array}{l}(3) \\
\text { IV }\end{array}$ & $\begin{array}{l}(4) \\
\text { IV }\end{array}$ \\
\hline $\begin{array}{l}\text { regional log affiliate employment: } \\
\qquad\left(\ln M_{i t}\right)\end{array}$ & $\begin{array}{c}0.048^{* * *} \\
(0.018)\end{array}$ & $\begin{array}{c}0.048^{* * *} \\
(0.018)\end{array}$ & $\begin{array}{c}0.036^{* * *} \\
(0.010)\end{array}$ & $\begin{array}{c}0.036 * * * \\
(0.009)\end{array}$ \\
\hline $\ln \left(G D P_{u s}+G D P_{d}\right)$ & & $\begin{array}{l}-0.084 \\
(0.129)\end{array}$ & & $\begin{array}{l}-0.072 \\
(0.463)\end{array}$ \\
\hline $\ln \left(G D P_{u s}-G D P_{d}\right)^{2}$ & & $\begin{array}{c}0.035 \\
(0.065)\end{array}$ & & $\begin{array}{c}0.037 \\
(0.231)\end{array}$ \\
\hline ln(Skill Difference) & & $\begin{array}{c}0.264 \\
(0.182)\end{array}$ & & $\begin{array}{c}0.03 \\
(0.059)\end{array}$ \\
\hline $\ln$ (Trade Costs) & & $\begin{array}{l}-0.114 \\
(0.087)\end{array}$ & & $\begin{array}{l}-0.039 \\
(0.030)\end{array}$ \\
\hline BIT & & $\begin{array}{l}-0.121 \\
(0.101)\end{array}$ & & $\begin{array}{l}-0.282 \\
(0.353)\end{array}$ \\
\hline FTA & & $\begin{array}{c}0.050 * * * \\
(0.014)\end{array}$ & & $\begin{array}{c}0.171^{* * *} \\
(0.047)\end{array}$ \\
\hline Exchange Rate & & $\begin{array}{c}0.000 \\
(0.0001)\end{array}$ & & $\begin{array}{c}-0.000 \\
(0.0000)\end{array}$ \\
\hline Industry FE & YES & YES & YES & YES \\
\hline Year FE & YES & YES & YES & YES \\
\hline $\mathrm{N}$ & 6080 & 6080 & 6080 & 6080 \\
\hline R-sq & 0.7205 & 0.7242 & 0.7163 & 0.7196 \\
\hline First Stage F-Stat & - & - & 220.29 & 217.76 \\
\hline Endog Test P-Val & - & - & 0.0109 & 0.0073 \\
\hline
\end{tabular}

Notes: Documents the effects of BTT-induced changes in foreign-affiliate employment on domestic employment at the region level. First-stage F-statistics are large for all IV specifications, though the relevant F-statistics for weak-instrument concerns appear in columns (2) and (5) of Table 4 (see text for discussion). In all IV specifications, the equality of OLS and IV is rejected. Standard errors clustered by parent firm and year are in parentheses. *,**, and *** indicate significance at the 10,5 , and 1 percent levels, respectively. 


\section{A.6 Imputation in CBP Employment Data}

When the size of a particular cell would risk violating data confidentiality requirements, the County Business Patterns data report an employment range rather than the precise employment count. This issue does not arise in the industry-level analysis in Section 4.2.3, but does appear in the county-level data that we use to generate metro-area employment in Section 4.2.4. The results presented in the main text (Table 9) utilize an imputation procedure that replaces the employment ranges with their midpoints. For example, when the CBP data report an employment range of 0-19 employees, we impute a value of 10 . We use the midpoint of each reported range and impute 175,000 employees when the CBP data report employment $\geq 100,000$.

In order to ensure that this imputation procedure is not substantively affecting our findings, Table A15 presents metro-area results in which we treat the suppressed employment values as zeros rather than imputing them at the midpoint of the reported ranges. Comparing against Table 9, the results are quite similar, with the more careful imputation in the main text implying somewhat smaller magnitudes, but a similar qualitative interpretation. 
Table A15: U.S. Metro Area Level Analysis:

The Effect of Offshore Employment on U.S. Regional Employment

Alternative Imputation

Dependent variable: $\log$ regional employment: $\ln \left(L_{m t}\right)$

\begin{tabular}{|c|c|c|c|c|}
\hline Specification: & $\begin{array}{c}(1) \\
\text { OLS }\end{array}$ & $\begin{array}{c}(2) \\
\text { OLS }\end{array}$ & $\begin{array}{l}(3) \\
\text { IV }\end{array}$ & $\begin{array}{l}\text { (4) } \\
\text { IV }\end{array}$ \\
\hline $\begin{array}{l}\text { regional log affiliate employment: } \\
\qquad\left(\ln M_{i t}\right)\end{array}$ & $\begin{array}{c}0.043^{* * *} \\
(0.012)\end{array}$ & $\begin{array}{c}0.042^{* * *} \\
(0.013)\end{array}$ & $\begin{array}{l}0.026^{* *} \\
(0.005)\end{array}$ & $\begin{array}{c}0.025 * * * \\
(0.005)\end{array}$ \\
\hline $\ln \left(G D P_{u s}+G D P_{d}\right)$ & & $\begin{array}{c}0.201 \\
(0.210)\end{array}$ & & $\begin{array}{l}0.111^{*} \\
(0.065)\end{array}$ \\
\hline $\ln \left(G D P_{u s}-G D P_{d}\right)^{2}$ & & $\begin{array}{l}-0.132 \\
(0.070)\end{array}$ & & $\begin{array}{c}-0.067 * * \\
(0.033)\end{array}$ \\
\hline $\ln ($ Skill Difference) & & $\begin{array}{l}0.336^{*} \\
(0.191)\end{array}$ & & $\begin{array}{l}0.110^{*} \\
(0.064)\end{array}$ \\
\hline $\ln ($ Trade Costs $)$ & & $\begin{array}{l}-0.011 \\
(0.068)\end{array}$ & & $\begin{array}{c}0.002 \\
(0.022)\end{array}$ \\
\hline $\mathrm{BIT}$ & & $\begin{array}{c}0.06 \\
(0.129)\end{array}$ & & $\begin{array}{c}0.042 \\
(0.044)\end{array}$ \\
\hline FTA & & $\begin{array}{l}0.268^{* * *} \\
(0.099)\end{array}$ & & $\begin{array}{c}0.096 * * * \\
(0.035)\end{array}$ \\
\hline Exchange Rate & & $\begin{array}{c}-0.0003^{*} \\
(0.000)\end{array}$ & & $\begin{array}{l}-0.000 \\
(0.000)\end{array}$ \\
\hline Industry FE & YES & YES & YES & YES \\
\hline Year FE & YES & YES & YES & YES \\
\hline $\mathrm{N}$ & 6080 & 6080 & 6080 & 6080 \\
\hline R-sq & 0.7229 & 0.7271 & 0.7189 & 0.7239 \\
\hline First Stage F-Stat & - & - & 182.15 & 175.54 \\
\hline Endog Test P-Val & - & - & 0.0211 & 0.0265 \\
\hline
\end{tabular}

Notes: Documents the effects of BTT-induced changes in foreign-affiliate employment on domestic employment at the region level. Suppressed county employment values in the County Business Patterns are treated as zeros when computing regional employment. See Table 9 for the results using a more careful imputation. First-stage F-statistics are large for all IV specifications, though the relevant F-statistics for weak-instrument concerns appear in columns (2) and (5) of Table 4 (see text for discussion). In all IV specifications, the equality of OLS and IV is rejected. Sample covers 1987-2007. Standard errors clustered by parent firm and year are in parentheses. ${ }^{*}, * *$, and ${ }^{* * *}$ indicate significance at the 10,5 , and 1 percent levels, respectively. 


\section{B Supplemental Theoretical and Econometric Results}

\section{B.1 Detailed Model of Double Taxation}

In this section, we consider double taxation in the context of the U.S. corporate tax, demonstrating the conditions under which we can model double taxation as a proportional increase in the costs of foreign affiliate employment, $\tau_{c t i}$ in equation (5) of the main text.

The U.S. taxes worldwide profits, but provides a credit for foreign tax liabilities in an effort to avoid double taxation. However, the U.S. offers only a limited credit, such that a multinational firm cannot claim a credit larger than the tax the U.S. would levy on foreign earnings (otherwise the U.S. tax authority would effectively subsidize foreign tax liabilities). The limited tax credit for foreign taxes paid can then subject the multinational firm to double taxation. To see how the incidence of double taxation arises with a limited foreign tax credit, here we derive the total taxes paid in each jurisdiction and the total tax liability of the multinational enterprise

Let $\phi$ denote the share of revenue that is remitted to the U.S. parent firm ${ }^{34}$ The domestic and foreign tax rates are $t$ and $t^{*}$, where we assume $t>t^{*}$ reflecting the fact that the U.S. has one of the highest corporate tax rates in the world. Moreover, the foreign tax authority collects an additional withholding tax on royalties, interest, and dividends. We denote the foreign withholding rate by $h^{*}$.

Given this notation, the taxes paid to the foreign tax authority are the corporate tax on the income of the affiliate plus the withholding tax:

$$
\underbrace{t^{*}\left[(1-\phi) r-w_{c} m\right]}_{\text {foreign corporate tax }}+\underbrace{h^{*} \phi r}_{\text {withholding tax }} .
$$

The U.S. tax liability for the multinational enterprise is the tax on worldwide income less any credit for foreign taxes paid. The tax on worldwide income can be written as $t[\phi r-$ $\omega s]+t\left[(1-\phi) r-w_{c} m\right]$ to reflect the domestic and foreign components of worldwide income. The firm is then eligible for a foreign tax credit designed to avoid double taxation, but this credit is limited so that it can not exceed the U.S. tax liability on foreign activities, $t\left[(1-\phi) r-w_{c} m\right]$. Thus, if this value is smaller than the foreign tax payments in (19), the foreign tax credit limit binds, and the firm faces double taxation. Combining terms, the U.S. tax liability, including the potentially limited foreign tax credit is

$$
\underbrace{t[\phi r-\omega s]+t\left[(1-\phi) r-w_{c} m\right]}_{\text {U.S. worldwide corporate tax }}-\underbrace{\min \left\{t^{*}\left[(1-\phi) r-w_{c} m\right]+h^{*} \phi r, t\left[(1-\phi) r-w_{c} m\right]\right\}}_{\text {foreign tax credit }},
$$

Summing the foreign and domestic tax liabilities yields the total tax burden of the multinational firm.

$$
t\left[\phi r-\omega s-w_{c} m\right]+\max \left\{0, t^{*}\left[(1-\phi) r-w_{c} m\right]+h^{*} \phi r-t\left[(1-\phi) r-w_{c} m\right]\right\}
$$

\footnotetext{
${ }^{34}$ In the context of the Antràs and Helpman (2004) model outlined in Section 4.1 the U.S. parent earns a share $\phi \equiv\left[\delta_{c}^{\alpha_{i}}+\beta\left(1-\delta_{c}^{\alpha_{i}}\right)\right]$ of total revenue, while the foreign affiliate earns a share $1-\phi \equiv(1-\beta)\left(1-\delta_{c}^{\alpha_{i}}\right)$. Yet, the following discussion about limits on foreign tax credits and the efficacy of BTTs holds for any determination of $\phi$.
} 
The first term reflects the U.S. worldwide tax system, which in the absence of double taxation imposes the U.S. tax rate on global taxable income. The second term reflects the possibility of double taxation, which occurs only when the foreign tax credit limit binds, increasing the total tax liability above what the U.S. worldwide system would impose. This expression makes clear two important points. First, higher withholding tax rates, $h^{*}$, make it more likely that double taxation occurs, which explains why BTTs aim to reduce withholding rates as a mechanism for lowering double taxation. Second, the double taxation relief from a reduction in the withholding tax rate is increasing in $\phi r$; i.e., the total payments to the U.S. parent. This fact motivates our delineation between high and low RID industries as we measure treatment arising from BTTs.

We now consider the implications of this tax structure for the multinational parents' and affiliates' employment choices. We assume that any foreign tax credit goes to the affiliate for their foreign tax payments. Generally, we require only that any burden of double taxation to the parent is uncorrelated with the change in withholding rates following a new BTT. In this case, the parent's problem is

$$
\max _{s} \phi r-\omega s-t[\phi r-\omega s]
$$

Note that the withholding tax rate $h^{*}$ does not enter the parent's problem in (22), explicitly demonstrating that the effects of BTTs in reducing withholding rates are excluded from parent hiring decisions. Solving the parent's problem and reintroducing subscripts yields the following first order condition.

$$
\begin{aligned}
& \ln s_{t}(f)= \\
& \underbrace{\ln \eta_{i}+\frac{\ln \alpha_{i}-\ln \omega-\ln (1-t)+\alpha_{i}\left[\ln \theta(f)-\left(1-\eta_{i}\right) \ln \left(1-\eta_{i}\right)\right]+\ln \left(\phi_{c i}(1-t)\right)}{1-\alpha_{i} \eta_{i}}}_{\psi_{f c i}} \\
& \underbrace{-\frac{\alpha_{i}-\mu}{1-\alpha_{i} \eta_{i}} \ln X_{t i}}_{\vartheta_{t i}}+\frac{\alpha_{i}\left(1-\eta_{i}\right)}{1-\alpha_{i} \eta_{i}} \ln m_{c t}(f) .
\end{aligned}
$$

We can collect the terms in the first line on the right side of the equal sign in an affiliate-level fixed effect, $\psi_{f c i}$, and the first term on the second line into an industry-time fixed effect, $\vartheta_{t i}$. This expression corresponds to (6) in the main text.

The affiliate pays the foreign tax and faces partial reimbursement when the foreign tax credit limit is reached. Specifically, the affiliate's problem is

$$
\begin{aligned}
\max _{m}(1-\phi) r-w_{c} m & -t^{*}\left[(1-\phi) r-w_{c} m\right]-h^{*} \phi r \\
& +\min \left\{t^{*}\left[(1-\phi) r-w_{c} m\right]+h^{*} \phi r, t\left[(1-\phi) r-w_{c} m\right]\right\} .
\end{aligned}
$$

When the foreign tax credit does not bind, the affiliate is fully reimbursed for its tax payments and the withholding tax rate drops out of the problem. In this case, a change in the withholding tax resulting from a BTT would have no effect on firm incentives, and we would not observe the various empirical effects that we document. If instead double taxation is 
present because the foreign tax credit does bind for some firms, changes in withholding tax rates do affect the affiliate's problem. In this case (24) reduces to.

$$
\max _{m}(1-\phi) r-w_{c} m+\left(t-t^{*}\right)\left[(1-\phi) r-w_{c} m\right]-h^{*} \phi r
$$

Solving the affiliate's problem and reintroducing subscripts yields the following first order condition.

$$
\begin{aligned}
\ln m_{c t}(f)= & \underbrace{-\frac{\alpha_{i}-\mu}{1-\alpha_{i}\left(1-\eta_{i}\right)} \ln X_{t i}}_{\zeta_{t i}} \\
& +\underbrace{\ln \left(1-\eta_{i}\right)+\frac{\alpha_{i}\left[\ln \theta(f)-\eta_{i} \ln \eta_{i}\right]+\ln \alpha_{i}-\ln w_{c}-\ln \left(1+t-t_{c}^{*}\right)}{1-\alpha_{i}\left(1-\eta_{i}\right)}}_{\nu_{f c i}} \\
& +\frac{\alpha_{i} \eta_{i}}{1-\alpha_{i}\left(1-\eta_{i}\right)} \ln s_{t}(f)+\frac{1}{1-\alpha_{i}\left(1-\eta_{i}\right)} \ln \left[\left(1+t-t_{c}^{*}\right)\left(1-\phi_{c i}\right)-h^{*} \phi_{c i}\right] .
\end{aligned}
$$

Again, we can group terms into an affiliate fixed effect, $\nu_{f c i}$, and an industry-time fixed effect, $\zeta_{t i}$. Affiliate employment relates to parent employment, fixed effects, and the final term that depends upon withholding rates, $h^{*}$. Note that the last term in equation (26) corresponds precisely to the last term in (7) in the main text, so that a reduction in $h^{*}$ corresponds to a reduction in $\tau_{c t i}$. BTTs lower withholding rates in an effort to resolve double taxation, which is equivalent to a decline in $\tau_{c t i}$, as modeled in the main text. Thus, the simplified notation in the main text is equivalent to this more detailed model of how BTTs lower effective tax rates for firms experiencing double taxation. 


\section{B.2 Model with CES Production}

In Section 4 we consider a model with a Cobb-Douglas production function, following Antràs and Helpman (2004). In this section we derive the relationship between foreign affiliate employment and domestic parent employment using a CES production production function. In this more general setting, the effect of affiliate employment on parent employment may be positive or negative, depending upon the relative size of scale and substitution effects.

We suppress subscripts to simplify notation. The CES production function is given by

$$
x=\theta\left(\eta s^{\rho}+(1-\eta) m^{\rho}\right)^{\frac{1}{\rho}} .
$$

where $\sigma=\frac{1}{1-\rho}$ indicates the elasticity of substitution between domestic and foreign labor.

The parent's problem is $\max _{s} A_{s} r-\omega s$, where $r=X^{\mu-\alpha} x^{\alpha}$, and $A_{s} \equiv \delta^{\alpha}+\beta\left(1-\delta^{\alpha}\right)$. Let $B_{s} \equiv A_{s} X^{\mu-\alpha} \alpha \eta \theta^{\rho}$, so that the parent's first-order condition can be written

$$
B_{s} x^{\alpha-\rho} s^{\rho-1}=\omega
$$

The affiliate's problem is $\max _{m} A_{m} r-w_{c} m$, where $A_{m} \equiv(1-\beta)\left(1-\delta^{\alpha}\right)$.

Let $B_{m} \equiv A_{m} X^{\mu-\alpha} \alpha(1-\eta) \theta^{\rho}$, so the affiliate's first-order condition can be written

$$
B_{m} x^{\alpha-\rho} m^{\rho-1}=w_{c}
$$

Combining the first-order conditions, we can solve for parent hiring $s$ as a function of parameters, which yields

$$
s=B_{s}^{\frac{1}{1-\alpha}} \omega^{\frac{-1}{1-\alpha}} \theta^{\frac{\alpha-\rho}{1-\alpha}}\left(\eta+(1-\eta)\left(\frac{\omega B_{m}}{w_{c} B_{s}}\right)^{\sigma-1}\right)^{\frac{\alpha-\rho}{\rho(1-\alpha)}}
$$

Our goal is to determine the effect of a change in the cost of foreign hiring $w_{c}$ on $s$ (note that the effect of a change in $w_{c}$ is isomorphic to a change in the $\tau$ in the main body of the text). Thus, we want to obtain

$$
\frac{d \ln s}{d \ln w_{c}}=\frac{d \ln s}{d w_{c}} w_{c}
$$

We first calculate

$$
\frac{d \ln s}{d w_{c}}=\frac{\alpha-\rho}{\rho(1-\alpha)} \cdot \frac{1}{\eta+(1-\eta)\left(\frac{\omega B_{m}}{w_{c} B_{s}}\right)^{\sigma-1}} \cdot(1-\eta)\left(\frac{\omega B_{m}}{B_{s}}\right)^{\sigma-1}(1-\sigma) w_{c}^{-\sigma} .
$$

Then, simplifying and using $\frac{1-\sigma}{\rho}=-\sigma$ and the expression in 31 we have

$$
\frac{d \ln s}{d \ln w_{c}}=\underbrace{(\rho-\alpha)}_{\text {determines sign }} \cdot \underbrace{\frac{(1-\eta) \sigma}{1-\alpha}}_{>0} \cdot \underbrace{\frac{w_{c}^{\sigma-1}}{\eta+(1-\eta)\left(\frac{\omega B_{m}}{w_{c} B_{s}}\right)^{\sigma-1}}}_{>0}
$$

The sign of (33) is determined by the sign of $\rho-\alpha$ and may generally be positive or negative. 
The parameter-dependent relationship between foreign affiliate hiring and parent employment is intuitive. The substitution effect between $s$ and $m$ contributes a positive component to (33), since a decrease in $w_{c}$ drives a decrease in the demand for $s$, holding output fixed. As $\rho$ approaches 1, the inputs become stronger substitutes, so this substitution effect grows in magnitude. The scale effect contributes a negative component to (33), since a decrease in $w_{c}$ drives a decrease in output price, an increase in output quantity, and an increase in $s$. The demand elasticity is $\frac{1}{1-\alpha}$, so as $\alpha$ gets larger, demand becomes more elastic, and the scale effect gets larger. The balance between $\rho$ and $\alpha$ corresponds to the balance between substitution and scale effects determining the overall sign of the effect. Under the Cobb-Douglas restriction $\rho=0$, so $\rho-\alpha<0$ and a decrease in offshore costs increases domestic employment. Our empirical results confirm that scale effect dominates on average in our sample, and additional offshore hiring by U.S. multinational firms leads to greater employment at domestic parent firms. 


\section{B.3 Smearing}

In Section 4.2.2, we discuss the need to aggregate affiliate-level predicted values from the first-stage regression in (11) up to the parent-firm level. Because this aggregation involves nonlinear transformations, we must account for the sampling distribution of the affiliate-level predictions using a procedure known as "smearing."

The affiliate-level first-stage regression in (11) yields predicted values for log affiliate employment, $\widehat{\ln m_{a t}}$. Our objective is to generate an unbiased estimate of log total affiliate employment at the parent firm level, $\widehat{\ln M_{f t}}$, where $M_{f t} \equiv \sum_{a \in f} m_{a t}$. Rewriting this aggregation definition to incorporate logs,

$$
\ln M_{f t}=\ln \left(\sum_{a \in f} \exp \left(\ln m_{a t}\right)\right) .
$$

This expression makes clear that there are three steps in constructing an estimate of $\ln M_{f t}$ from the constituent $\widehat{\ln m_{a t}}$.

First, we generate unbiased estimates of $m_{a t}=\exp \left(\ln m_{a t}\right)$. Assume that the errors in (11) are i.i.d. and normally distributed, $\epsilon_{a t} \sim N\left(0, \sigma^{2}\right)$, and refer to the regressors and coefficients on the right side of (11) as $\boldsymbol{X}_{a} \boldsymbol{\beta}$. Then $m_{a t}$ is lognormally distributed with location parameter $\boldsymbol{X}_{a} \boldsymbol{\beta}$ and variance parameter $\sigma^{2}$. Thus, $E\left[m_{a t}\right]=\exp \left(\boldsymbol{X}_{a} \boldsymbol{\beta}+\frac{\sigma^{2}}{2}\right)$, which we can estimate as $\hat{m}_{a t}=\exp \left(\boldsymbol{X}_{a} \hat{\boldsymbol{\beta}}+\frac{\hat{\sigma}^{2}}{2}\right)$. Similarly, we can use the variance of the lognormal distribution to estimate $\operatorname{var}\left(\hat{m}_{a t}\right)=\left(\exp \left(\hat{\sigma}^{2}\right)-1\right) \cdot \exp \left(2 \boldsymbol{X}_{a} \boldsymbol{\beta}+\hat{\sigma}^{2}\right)$.

Second, we must sum across sibling affiliates to estimate $M_{f t} \equiv \sum_{a \in f} m_{a t}$. Since the summation operator is linear, we can construct

$$
\widehat{M_{f t}}=\sum_{a \in f} \hat{m}_{a t}=\sum_{a \in f} \exp \left(\boldsymbol{X}_{a} \hat{\boldsymbol{\beta}}+\frac{\hat{\sigma}^{2}}{2}\right) .
$$

Assuming zero covariance between errors for sibling affiliates, the variance estimate for $\widehat{M_{f t}}$ is

$$
v \hat{a} r\left(\widehat{M}_{f t}\right)=\sum_{a \in f} v \hat{a} r\left(\hat{m}_{a t}\right)=\sum_{a \in f}\left[\left(\exp \left(\hat{\sigma}^{2}\right)-1\right) \cdot \exp \left(2 \boldsymbol{X}_{a} \boldsymbol{\beta}+\hat{\sigma}^{2}\right)\right] .
$$

Finally, we need to estimate the log of total affiliate employment at the parent level, $\widehat{\ln M_{f t}}$. Note that the sum of lognormal random variables is well approximated by a lognormal distribution (Mehta et al. 2007). Thus, we simply implement the reverse of the lognormal transformation from the first step. Therefore, our estimate of parent-level log total affiliate employment is

$$
\begin{gathered}
\widehat{\ln M_{f t}}=\ln \mu-\frac{1}{2} \ln \left(\frac{s^{2}}{\mu^{2}}+1\right), \\
\text { where } \mu=\widehat{M_{f t}}=\sum_{a \in p} \exp \left(\boldsymbol{X}_{a} \hat{\boldsymbol{\beta}}+\frac{\hat{\sigma}^{2}}{2}\right) \\
\text { and } s^{2}=v \hat{a} r\left(\widehat{M_{f t}}\right)=\sum_{a \in p}\left[\left(\exp \left(\hat{\sigma}^{2}\right)-1\right) \cdot \exp \left(2 \boldsymbol{X}_{a} \boldsymbol{\beta}+\hat{\sigma}^{2}\right)\right] .
\end{gathered}
$$


Our parent-level estimates of predicted total affiliate employment are constructed following (37). Because the final step of this process involves an approximation, we implemented alternatives including a naive plug-in estimate and a nonparametric smearing procedure following Duan (1983), finding very similar results. 


\section{References}

Pol Antràs and Elhanan Helpman. Global sourcing. Journal of Political Economy, 112(3): 552-580, 2004.

Naihua Duan. Smearing estimate: A nonparametric retransformation method. Journal of the American Statistical Association, 78(383):605-610, 1983.

Neelesh Mehta, Jingxian Wu, Andreas Molish, and Jin Zhang. Approximating a sum of random variables with a lognormal. IEEE Transactions on Wireless Communications, 6 (7), 2007. 